of Iransportation

National Highway

Traffic Satety

Administration

DOT HS 807963

September 1992

Final Report

\title{
Procedures and Resource Guide for Bicycle Helmet Promotions: A Review of Bicycle Helmet Promotions in the United States
}


This publication is distributed by the U.S. Department of Transportation, National Highway Traffic Safety Administration, in the interest of information exchange. The opinions, findings and conclusions expressed in this publication are those of the author(s) and not necessarily those of the Department of Transportation or the National Highway Traffic Safety Administration. The United States Government assumes no liability for its contents or use thereof. If trade or manufacturers' name or products are mentioned, it is because they are considered essential to the object of the publication and should not be construed as an endorsement. The United States Government does not endorse products or manufacturers. 
Technical Report Documentation Page

\begin{tabular}{|c|c|}
\hline $\begin{array}{l}\text { 1. Report No. } \\
\text { DOT HS } 807963\end{array}$ & 3. Recipient's Cotolog $\mathrm{No}$. \\
\hline \multirow{2}{*}{$\begin{array}{l}\text { 4. Tirle and Subtitle } \\
\text { Procedures And Resource Guide For Bicycle Helmet } \\
\text { Promotions: A Review of Bicycle Helmet Promotions } \\
\text { In The United States }\end{array}$} & $\begin{array}{l}\text { 5. Report Date } \\
\text { April } 1992\end{array}$ \\
\hline & 6. Performing Orgonization Code \\
\hline $\begin{array}{l}\text { 7. Author's! } \\
\text { Linda Tracy }\end{array}$ & 8. Performing Organization Report No. \\
\hline 9. Performing Organization Name and Address & 10. Work Unit No. (TRAIS) \\
\hline \multirow{2}{*}{$\begin{array}{l}\text { Bicycle Federation of Americ } \\
\text { Montana Office } \\
\text { P.0. Box } 8315 \\
\text { Missoula. MT } 59807-3315\end{array}$} & $\begin{array}{l}\text { 11. Controct or Grant No. } \\
\text { DTHN 22-90-P-07107 }\end{array}$ \\
\hline & $\begin{array}{l}\text { 13. Type of Report and Period Covered } \\
\text { Final Report }\end{array}$ \\
\hline $\begin{array}{l}\text { 12. Sponsoring Ageney Name ond Addess } \\
\text { National Highway Traffic Safety Administration } \\
400 \text { Seventh St. SW }\end{array}$ & $\begin{array}{l}\text { Final Report } \\
\text { Contract Period } \\
2 / 90 \text { to } 12 / 91 \\
\end{array}$ \\
\hline Nashington, DC 20590 & 14. Sponsoring Agency Code \\
\hline
\end{tabular}

15. Supplomentary Notes

16. Abstruct

Review of 231 national, state, and local bicycle helmet promotions in the U.S. based on a Bicycle Federation of America survey conducted in summer 1991. Report identifies trends, common elements of successful programs, goals, strategies, and level and type of evaluation. Examples of helmet promotion resources, materials, guides, and manuals are discussed. Various factors that initiated promotions, and barriers that challenged progress are also included. Directory of programs lists contact information plus target audience, promotion strategy, level of funding, project length, geographic area, level of evaluation, and whether or not the promotion was a coalition effort.

17. Koy Words

Bicycle helmet, bike helmet, bicycle helmet promotion, bicycle helmet campaign, bike helmet promotion, bike helmet campaign

19. Security Classif. (of this report) Unclassified
20. Security Classif. (of this poge) Unclassified
18. Distribution Statement

Available to the public through the National Technical Information Service, Springfield, VA 22161 
TABLE OF CONTENTS

page

INTRODUCTION $\ldots \ldots \ldots \ldots \ldots \ldots \ldots \ldots \ldots \ldots \ldots \ldots \ldots$

ISSUES ASSOCIATED WITH HELMET PROMOTION $\ldots \ldots \ldots \ldots . .3$

ELEMENTS OF PROMOTION $\ldots \ldots \ldots \ldots \ldots \ldots \ldots \ldots \ldots \ldots \ldots \ldots$

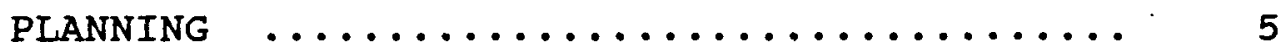

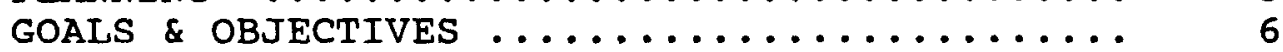

TARGETING $\ldots \ldots \ldots \ldots \ldots \ldots \ldots \ldots \ldots \ldots$

Audience

Project Length

Geographic Area

Mass Media

Materials

STRATEGIES \& ACTIVITIES ............... 10

Public Information \& Education $\ldots \ldots \ldots .11$

Statements of Policy

Information Dissemination

Special Events

Materials Distribution

Helmet Distribution ............. 16

Availability

Incentives to Buy

Low Income and Give-Away Programs

Loaner Programs

Helmet Use .................... 18

Required or Mandatory Use

Incentives and Rewards

SUPPORT $\quad \ldots \ldots \ldots \ldots \ldots \ldots \ldots \ldots \ldots \ldots \ldots$

Campaign Coordinators

Funding

Technical Assistance

EVALUATION

Impact

Process

CONCLUSIONS $\ldots \ldots \ldots \ldots \ldots \ldots \ldots \ldots \ldots \ldots \ldots \ldots \ldots \ldots \ldots$

APPENDICES $\ldots \ldots \ldots \ldots \ldots \ldots \ldots \ldots \ldots \ldots \ldots \ldots \ldots \ldots \ldots \ldots \ldots$

APPENDIX A: "How To" Promotion Guides \& Other Support

APPENDIX B: Local Resources 
TABLE OF CONTENTS (Continued)

APPENDIX C: Governor's Highway Safety Representatives and Coordinators

APPENDIX D: Directory of National Organizations

APPENDIX E: Directory of Promotions

APPENDIX F: Directory of state Bicycle and Pedestrian Coordinators

APPENDIX G: Sample Survey 


\section{INTRODUCTION}

This procedures and resource guide for promoting bicycle helmet usage is based on a review of bicycle helmet promotions in the United states. The report identifies who is promoting helmet use and the program elements common to successful promotions. Examples of awareness building, helmet distribution, and helmet use activities are provided. Factors that motivated people to begin campaigns, have helped or challenged their progress, and essential elements required to start and conduct a promotion also are presented.

The source for the information presented in this report was a survey conducted by the Bicycle Federation of America in the summer of 1991. Surveys were mailed to over 550 separate organizations and individuals identified through personal contacts, bicycle helmet manufacturers and distributors, traffic safety and injury control government officials, and organizations administering various mini-grant programs. over 230 of these organizations and individuals responded with information. A summary of individual responses are provided in Appendix $E$ and the survey is presented in Appendix F.

Bicycle helmet promoters were asked what had motivated them or their organizations to become interested in promoting bicycle helmets and what factors helped them initiate a program. Many individuals and organizations were motivated to begin promoting helmets by some sort of experience with a bicycle crash or injury. For some, this was the result of the death or injury of a family member or young patient.

For others, it was the knowledge of the severity of head injuries caused by bicycle crashes or falls, and awareness of a relatively inexpensive, easy to implement, widely available countermeasure that could prevent or reduce the severity of the injuries. others were drawn by other personal, interests. For example, the challenge of getting their own children to initially try helmets and then continue to wear them prompted some parents to initiate helmet promotions in their neighborhood, schools, or community. A child who wore a helmet in elementary school, but became very reluctant to continue doing so as a middle school student, prompted one parent to begin efforts to target increased use by older children. Avid bicyclists have become involved in order to share what they know with others. The general concern for giving back to one's community, for public safety, and for saving lives and preventing injuries was the motivation for other promotions. 
The emphasis of injury prevention in the health care, public health, and safety fields has stimulated promotions, especially when funding has been made available. Discussions about mandatory helrnet use and specific legislation introduced or passed also played a role in initiating program activity. Several promotions were begun to increase the availability of helmets, others to provide free or discounted helmets to riders from low income families.

Several general trends emerged from the survey results. The majority of helmet promotion campaigns targeted young children and their parents. There were very few that targeted teenagers or older adults. Most promotions offered some form of incentive to either encourage helmet purchase, in general, or to motivate a helmet purchase immediately following some form of educational activity. Typically, the campaigns were planned and conducted at the local level, being coordinated by community-based coalitions.

The majority of promotions which responded to the survey reported collecting little or no evaluation data, or performing any type of systematic evaluation. Most indicated that this was primarily due to limited resources. Many respondents did cite anecdotal results such a:s, "sold lots of helmets," "increases in use noted," and, "It worked." Evaluation information and data was provided by approximately 25 percent of those surveyed.

The following sections identify barriers to conducting a promotion, provide information for conducting a successful bicycle helmet promotion campaign, and provide a resource guide of promotions, many of which have information or materials available for others. The scope of this project did not allow for the identification or reporting on every bicycle helmet promotion in the country. Nor did it allow full recognition of all the work being done in the campaigns highlighted in the report or identified in the resource guide. 


\section{ISSUES ASSOCIATED WITH HELMET PROMOTION}

Numerous possible issues are faced by those wishing to increase the use of bicycle helmets in their community. These include factors associated with low helmet use and other specific program challenges.

One reason for low bicycle helmet use has been identified as a lack of awareness and understanding of head injury by parents, by children, and by the public in general. This is accompanied by a lack of awareness and understanding of helmets and their effectiveness. Many people have never thought of wearing a helmet or never thought it was really necessary. There are dangerous myths about bicycle-related crashes and the resultant injuries. People, and parents in particular, report a helmet isn't necessary because they or their children don't ride in traffic, ride very far, or ride very often. Some adult riders seem to feel helmets are only for children. This is evidenced by the widespread incidence of adult riders not using helmets while their child passengers are wearing them.

Public awareness and public information and education (PI\&E) are essential to a successful campaign as mass media can be quite effective in increasing the awareness of target audiences. However, some promaters have been frustrated in their attempts to establish contacts and have their information used by various mass media outlets. Most mass media outlets are busy and have little time available for all the public service requests they receive.

Even with the support of mass media and other PI\&E activities, increased awareness alone does not guarantee helmet purchase or sustained use among bicyclists. For example, a study in Georgia found 80 percent of parents reported being exposed to helmet messages, but only 20 percent of their children had helmets.

Another factor that contributes to low use is the lack of helmet availability, especially low cost helmets. Helmets have become more widely available in the past two or three years. Large discount department stores, where most bikes are purchased, now stock low cost ANSI or snell certified helmets. But the selection may be limited to one or two models, or shelf displays in some stores may be difficult to find.

Other barriers to helmet use cited in the survey were riders concerns of looking ridiculous or concerns about peers and acceptance, especially among older school age children. Low peer 
usage among both children and adults contributes to these perceptions.

Any campaign that tries to increase helmet use among youngsters almost always involves the local schools. However, working with school administrators and teachers can be difficult. School systems are overburdened with requests and requirements for additional or increased time for new or existing topics and subject areas. Most schools feel they cannot accept any additional efforts, despite the importance. It is up to the campaign to convince administrators and teachers of the importance and criticality of helmet promotion. Some campaigns have had difficulty using helmet coupons in the schools as they are perceived by the schools as official school endorsement of a particular brand or retail store over another.

Means of overcoming these and other barriers are presented in the following sections of the report. Specific examples, where appropriate, are used from actual helmet promotion campaigns. 


\section{ELEMENTS OF PROMOTION}

The following basic elements were identified, after the review of hundreds of bicycle helmet promotions, as being associated with successful campaigns.

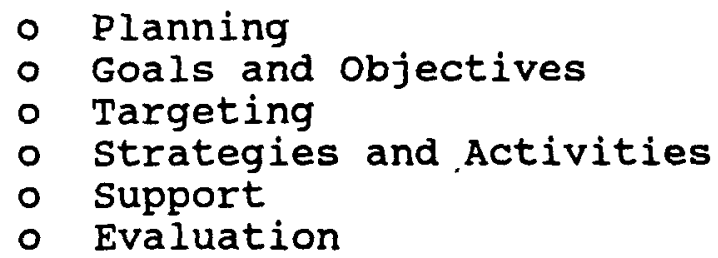

\section{PLANNING}

The hardest part of initiating a helmet promotion campaign often is knowing how to get started. Most successful promotions start with detailed planning. Essential campaign planning commonly includes addressing all the elements, and related issues, identified above.

An easy first step in planning is to get information from those who already have conducted a successful bicycle helmet promotion. Campaigns that have information and materials are referenced later in this section and listed in Appendix D.

Learn all about bicycle helmets. This includes the standards, the different types and sizes of helmets, how helmets must be fitted and worn to assure adequate protection, how to care for helmets, how to determine when a helmet must be replaced, and how to obtain both large and small quantities of helmets at discount rates.

In conducting a campaign, most promotions have found that organizing and building a community-based coalition with a strong leader and a local base of support, help make the campaign more effective, broaden its reach, and allow it to take advantage of additional local resources. Key coalition members might include medical providers, teachers and school administrators, PTA's, civic organization and business leaders, and government administrators. The coalition should be involved in all aspects of the program including planning, promotional activities, and evaluation.

Planning will involve gathering information on local injury statistics and helmet usage to identify problems and determine appropriate target audiences. Specific goals of the campaign 
should be determined from the problem identification and expressed in cilear, manageable and measurable objectives. Determine activities that will address the identified objectives and target audiences. Identify established local events or other community programs upon which to piggyback the helmet promotion activities. Using existing events and activities can facilitate the campaign and is a cost-effective approach for programs with limited funds. Develop an overall timetable for the activities.

The media is a potentially strong partner in reaching almost any target audience, so it is important to assemble a media package and develop a list of media contacts early in the project. If possible, involve a media representative in the coalition.

Level of funding and its sources must be determined and obtained. Additional local resources and in-kind funding must be identified. The available resources will provide parameters for the scope of the promotion, including staffing, amount and type of materials that will be used, promotion length, and geographic areas to be reached.

The planning phase is the time for determining what program materials will be needed and whether they will have to be developed, or need to be obtained from another source. Many promotions advise that it almost always takes longer than expected to develop or procure materials for the campaign.

Evaluation procedures and data requirements need to be identified. This will include the means of collecting and analyzing baseline, program, and post-program data.

The time needed for planning will vary by project, but for the most part, the program elements identified above will not. Depending on the level and type of promotion, the resources available, and the community, the level of planning for each element will vary. Time spent planning a promotion is usually time well spent.

\section{GOALS AND OBJECTIVES}

The goals and objectives of a campaign define what will be the intent of the campaign. The goals and objectives must be clear, concise, and measurable to allow organizers to determine if the objectives have been met with the program activities. The underlying goal of a bicycle helmet campaign is to reduce the incidence of bicycle-related head injuries through increased helmet use. Some campaigns also include, or are a part of, a bicycle safety program. The intent is to prevent bicycle-related crashes as well as crash injuries. 
Examples of typical objectives for bicycle helmet promotion are:

- Raise public awareness of head injuries resulting from bicycle-related crashes, and the need to use helmets to decrease or reduce the severity of these injuries.

This objective seeks to develop an awareness and understanding of head injuries and the role of bicycle helmets in preventing, and reducing the severity of, head injuries. There is little public understanding of the seriousness of bicycle head injuries and that they can be life threatening or can have long term consequences in reduced physical capabilities and extensive rehabilitative costs. Every campaign surveyed included some type of awareness building activity.

- Increase helmet availability and ownership

Once there is awareness of the need and desirability to use helmets, the next step is to provide approved helmets to the riding public. This objective addresses the availability of helmets to be sold or loaned, and activities to motivate riders to buy or obtain helmets.

- Increase helmet use

Even if riders have access to a helmet, it does not mean that they will use it. This objective addresses the need to get riders to remember to use the helmet on all trips.

- Gain peer acceptance of using helmets

This objective attempts to make helmet use more acceptable among bicyclists, especially children. Gaining peer acceptance of helmets increases the motivation of riders to use helmets.

- Motivate doctors, other important community leaders, and other role models to personally promote the use of bicycle helmets

This objective attempts to gain the support of important community leaders and other role models to promote the use of helmets. These individuals must support the campaign and should be involved as part of the coalition. The next step is to convince these individuals to take a more active, personal role in the promotion.

- Advocate the adoption of a mandatory helmet performance standard

This objective stems from the problems associated with the voluntary compliance status of current standards and the self-certifying nature of the ANSI standard. These problems 
raise questions regarding whether the current standards result in adequate protection for helmet users, particularly children. The issues have prompted many bicycle helmet advocates to call for the Consumer Product Safety Commission to develop a mandatory performance standard.

\section{TARGETING}

A helmet campaign can be more cost effective if it is targeted to a specific audience, in a particular area, for a determined period of time. This allows for promotional materials to be designed or adapted specifically for the program.

\section{Audience}

Promotions generally are more effective if the intended audience is specifically targeted. However, this requires that the promoters define who is to be the target audience. Audiences can be defined by age, grade level, or by relationship, for example, five to 10 year olds, K-6th grade students, or parents of school age children. Nost promotions surveyed focused on school aged children, with a majority also targeting the children's parents. The parents were most often seen as decision makers, purchasers, and enforcers of helmet use. A few promotions also targeted parents and other role models as cyclists and in need of as much protection as their children.

The rationale for targeting children is threefold: 1) they can establish a lifelong habit of helmet use; 2) they are easier to reach because they attend school; and 3 ) there is greater acceptance of helmets by younger children. There is, however, some concern about only targeting children (and their parents), particularly with regard to sustaining helmet use as they grow older. These concerns can be addressed by the targeting of teens and young adults.

A few campaigns targeted all ages or other specific ages, such as pre-school through first grade or early adolescents from sixth through eighth grade. Others targeted specialized audiences such as the "Sell a Bike, Save a Life" campaign developed by the VA Department of Motor Vehicles which targeted sales people at discount department stores where a majority of children's bicycles are sold. In Manville, NJ, bicycle-mounted Gannett newspaper carriers were targeted.

\section{Project Length}

Generally, the longer a promotion is conducted, the greater the potential impact. In the promotions surveyed, activities varied 
between single day events that happen once or once a year, to multi-year campaigns. Approximately 65 percent of the promotions surveyed were multi-year efforts. Often these longer campaigns have peak periods of activity just prior to and during the prime bicycling months and before christmas. In many cases, one day events, such as rodeos, originally intended to happen only once, have become annual events because of their popularity.

Geographic Area

Approximately 55 percent of the promotions focussed their efforts on the local community or county. Even national campaigns such as Safe Kids and the American Academy of Pediatrics focus much of their efforts on supporting local level activity. Depending on the media markets used by the promotion, it is best to concentrate on the local level. Often, more local support can be generated for promotions concentrated at the local level.

\section{Mass Media}

Mass media is able to reach large numbers of people with the same message. The cost of working with the media can be beyond the financial resources of a local campaign. However, helmets, bicycling, and children's safety are strong areas of interest to the public and therefore to the media. Many campaigns have used this fact to their best advantage by using news segments, talk show appearances, special event coverage, and victim stories. Some have found unique, - no cost ways to use mass media, such as in Pitt County, NC where a weatherman promoted helmets as he gave the nightly report and forecast. National efforts, such as the National Safe Kids Campaign, have helped expand the media resources of local campaigns by creating and distributing media kits, press releases, and PSA's.

The effectiveness of mass media alone to change behavior, in this case helmet use, is very limited. For example, before a program began in Georgia, 80 percent of the parents sampled reported prior exposure to helmet messages, most through the media (75\%). However, only 20 percent of these parents reported their children owned a helmet. Control and experimental schools were exposed to a mass media campaign. Only the experimental school, which also received both child and parent education, saw significant increases in helmet ownership (from $20 \%$ to 40\%) and usage (from $58 \%$ to $85 \%$ ).

\section{Materials}

The type and quantity of materials needed for a campaign depends on the objectives and target audience(s) of the promotion. A 
wide array of print, tape, film, and other materials have been created to promote awareness, distribution, and the use of helmets.

Some campaigns have reprinted and customized materials developed by other organizations or for other promotions. For example, the "Lou and his friends..." brochure created by the Head smart coalition was reprinted by the National Safe Kids campaign.

Revisions of existing materials can be made to include helmet messages, and include helmets on graphics and photographs of bicyclists. Examples are the pamphlet "Bicycle Safety: What Every Parent. Should know," various American Automobile Association bicycle safety materials, and the "complete Bicycle Education Program." Additional examples of materials from the survey are provided in the following section of the report.

The types of materials that could be used in a promotion include:

- Print materials - informational and awareness brochures, flyers, posters, activity books, hang tags, and incentives to buy, such as discount coupons, rebates, and sales flyers.

- Media kits - often include print and broadcast PSA's, and sample radio announcements and press releases.

- Newsletters and policy statements.

- Guides, "how to" documents, and sample presentations and curricula for parents and children.

- Videos - created to promote helmets by professional organizations, public agencies, and.children themselves.

\section{STRATEGIES AND ACTIVITIES}

Strategies are a common set of activities designed to accomplish the goals and objectives of, in this case, a helmet promotion campaign. Most successful promotions included multiple strategies and a variety of activities for each strategy. Local promotions can be creative in the number and type of activities used, but the planner(s) must be realistic in terms of available resources that will support the planned activities.

Research has been conducted or is currently in progress to determine effective strategies in changing attitudes toward helmets, helmet use and helmet sales, and the level of promotion required. Studies have been conducted by the Bicycle Federation of America for the Florida Department of Transportation and the Michigan Departinent of Health, and is being done (at the time 
this report was being prepared) by Dunlap \& Associates under a grant from the Centers for Disease Control.

\section{Public Information \& Education}

Every promotion should conduct activities designed to increase awareness through public information and education (PI\&E) about helmets and their effectiveness in preventing head injuries. This strategy is most effective when combined with one or more other strategies (e.g., helmet distribution, helmet use). Based on the survey, PI\&E activities to increase awareness broadly fall into one of four categories.

- Statements of policy

- Information dissemination

- Special events

- Materials distribution

- Statements of Policy

Several national groups have developed position or policy statements promoting the use of helmets and encouraging their constituents to get involved in the promotion. Examples include The National PTA, American Academy of Pediatrics, League of American Wheelmen, American Youth Hostels, National Safe Kids Campaign, and the American Medical Association Auxiliary.

Other organizations include helmet promotion as a component of an overall bicycle safety program. These include New Jersey and Ohio Departments of Transportation, the Guam office of Highway Safety, and the safety Village in Northampton, MA.

Helmets are required on all bicycling images produced by the President's Council on Physical Fitness. Other organizations have a similar policy or a position calling for others to do so. For many years, members of the Washington DC Area Bicyclists Association have been writing to advertisers who use bicycling in their commercials and advertisements. Kudos are sent to those who have included helmets, and information in favor of helmet use is sent to those who do not.

Information on bicycle helmets needs to be disseminated in as many ways as possible to increase the probability that the information reaches the target audiences. It is important to use established community delivery systems whenever possible to reach these target groups. This allows the campaign to take maximum advantage of limited resources, and the use of local networks. 
The following are examples of how different campaigns disseminated, and used information and various networks to promote bicycle helmets.

- North Carolina Department of Transportation created an information and materials sample packet, ran a statewide training session, and provided technical assistance to spawn local campaigns. They sent a letter to all bike shops prior to the Christmas season offering free hang tags with a helmet purchase message. Almost 100 shops ordered them.

- Washington DC Area Bicyclists Association began helmet promotion and consumer testing in 1974. In 1989, the Association created the Bicycle Helmet Safety Institute which distributes a "Consumer's Guide to Bicycle Helmets" brochure and a newsletter. Their Documentation Center contains over 350 helmet-related documents available for the cost of copying and mailing.

- Mayoral or City Council proclamations of Bicycle Helmet Week or Month have been signed in Mill Valley, CA and Rochester, NY. In Mill Valley, a banner was hung across the main street, a message was placed on the high school marquee, and a letter to parents of $\mathrm{k}-12$ th grade students from the mayor, PTA, school board, and every school principal helped spread information on helmets.

- The Northampton Saving Lives program identified 10 community role models who agreed to always wear a helmet and to be a rolling helmet campaign.

- Teenage Mutant Ninja Turtle helmet brochures and posters, in Spanish or English, are distributed to parents and children by the New York state Department of Health.

- The National Safe Kids Campaign compiled, published and disseminated information to local coalitions, media, and national organizations through conferences, local coalition networks, publications, satellite feeds, press releases and personal contacts.

- The Rcchester Helmet Coalition has sent letters to all area advertising agencies asking them to include helmets on all bicycling images.

- Packets of information are sent to area pediatricians by the New Jersey Association for Retarded Citizens, the Emmanuel Trauma Services, Portland, OR, and the 
Maryland Chapter of American Academy of Pediatrics. Packets include suggestions for patient counseling during visits, handouts for patients and parents, and "prescription pads" for the purchase of a helmet.

- Harborview Injury Prevention and Research Center developed and widely distributed information of their community-based program, including available materials, and program effectiveness. They also distributed a series of one-page, easily reproducible flyers, including "What Pre-Schools Can Do to Promote Bike Helmet Use," and similar pieces for physicians, youth groups, and schools.

- Area promotions using professional sports teams, such as the Detroit Red wings and the Pittsburgh steelers, Pirates, and Penguins, help gain acceptance for helmets, especially among young fans.

- American Academy of Pediatrics (AAP) created the TIPP (The Injury Prevention Program) encouraging

pediatricians to advise their patients to wear helmets. The AAP also sponsored a mini-grant program to foster promotion activity at the local level.

- New York Department of Health Injury Control Program developed the "Head Out with a Helmet" campaign, providing low-cost helmets to programs for children from low income families.

- Bicycle Helmet Safety Institute and The Bicycle Federation of America provided technical assistance, disseminated information and copies of documents to the media and the general public.

A variety of events and presentations can be used to provide awareness and educate the public. Events can be bicycle specific or in conjunction with other activities.

A common means of promoting awareness of bicycle helmets and bicycle safety is through a bicycle rodeo. Bicycle safety, riding skills and rules of the road are taught, and information about the importance of wearing helmets is disseminated. Often rodeos offer participants an opportunity to purchase a discount helmet on site or receive a discount coupon. For example, The Health Care Plan of Buffalo, NY provides a free helmet to children who participate in the bicycle rodeos. The rodeos are limited to the first 50 children who sign up. A rodeo held in conjunction with the Safe Kids Fair in West Palm Beach, FL has 
become an official school field trip for 5,000 students.

Poster contests help reinforce the importance of helmet use. Some contests, like the statewide one conducted annually by the Colorado Safe Kids Campaign, provide helmets as prizes. The contest includes a trip for the winners to Denver for the awards ceremony and a press conference with the governor.

Another common awareness strategy involves presentations to schools, PTA's, and other organizations. The video tape "Heads You Win," created for parents as part of the Pitt county, NC helmet campaigh, includes basic information about head injuries, the effectiveness of helmets, and what to look for when buying a helmet for a child.

Sprocketman/wonan, a lycra-clad superhero, made presentations to over 25,000 seattle school children. This superhero, a Cascade Bicycle Club member, promoted helmet use and basic bicycle safety principals. A coloring book, which reinforced key points, was distributed to each child.

\section{- Materials Distribution}

Awareness and PI\&E materials take many forms, including brochures, posters, hang tags, P.SA's, and videos, and can be distributed through multiple channels. The following are only a few examples of the type of materials that can be used to promote the use of bicycle helmets. Many of these materials are available to other promotions.

Brochures. Brochures have been developed for a number of audiences. One of the early, widely distributed brochures was "Protect Your Head. Where Would You Be Without It?" produced by the Injury Prevention Resource and Research Center, Dartmouth Medical School, Hanover, NH. Its first printing of 10,000 brochures "sold out" in five weeks.

"Buckle Up Your Baby" the first brochure to address helmets for toddlers was produced by the DC Department of Public Works. Distribution was limited to the District of Columbia, but the art-work was made available to others for reprinting.

"Lou and his friends...," originally created for the Head Smart Campaign, is probably the most widely distributed brochure. An estimated $1.5 \mathrm{million}$ copies have been distributed nationwide.

Posters. Posters have been created by many campaigns for display in schools, retail stores, doctor's offices, and child care facilities. Examples of posters created for children include "Helmet Power!" from Harborview, "Protection: You're Not Born with It" from the Head Smart campaign, and "Helmets" from the 
National Safe Kids Campaign. Several local campaigns also have created their own posters using athletes and celebrities. A poster for parents was created by Safe Kids and Bell Helmets to be displayed in physician's office waiting rooms.

Activity books. Several activity books have been created for children, including the "Head smart Activity Book," and "HIP (Head Injury Prevention) Tips" by the Children's Hospital of MI.

Hang tags. Hang tag messages have been designed to suggest the bike is missing a part, the helmet, and therefore creates the impression that a helmet is needed. Hang tags, first used in Seattle, have been used by others, including the North Carolina Departments of Transportation, and Environment, Health and Natural Resources, and the National Safe Kids Campaign. The Virginia safe Kids coalition has distributed hang tags to 73 bicycle shops throughout the state.

other print materials. other print materials include billboards - a year long display in Pitt county, NC was seen by an estimated 1,560,000 people; bus posters - posted on the backs of transit buses in San Diego, CA; and milk carton messages printed on the back of milk cartons in st. Louis, Mo.

Videos. Videos are very popular with promotions. They can be used in many different situations and allow for active graphical presentations. Children enjoy them and it's easy to maintain their attention with a video. Examples are the "Bicycle safety Camp" video for children produced by the American Academy of Pediatrics and Sandoz Pharmaceuticals which has been widely distributed through pediatrician's offices. It also was offered in Sunday advertising supplements for $\$ 9.95 \mathrm{with}$ proof of purchase from a Sandoz cough syrup. Several promotions reported distributing or loaning copies of this video to schools, libraries, and police departments.

The Rochester Bicycle Helmet Safety Coalition created "Elephants Never Forget," an animated, action video for $\mathrm{K}-2$ nd grade students highlighting bicycle safety and promoting helmet use. The NC Department of Environment, Health and Natural Resources created a video-slide presentation for parents, "Heads You Win," which introduces the need for helmets, their effectiveness, and what to look for when buying one.

Public service announcements. Television PSA's have been created by Harborview, National Safe Kids, Head Smart, National Safety Council, and several local groups. Safe Kids PSA's have been distributed to stations nationwide. In addition, most of these national groups have created various radio and print PSA's promoting helmets for use at the local level. 
Providing helmets to users can be done in many different ways. Activities to increase helmet ownership often involve motivating potential buyers with a coupon, rebate, sale, or discount offer. Informing the public about the availability and cost of helmets at various locations is yet another facet of encouraging helmet purchase. Four types of strategies that have been used to bring helmets to target audiences are:

$\begin{array}{ll}\text { - Availability } \\ \circ \quad \text { Incentives to buy } \\ 0 & \text { Low income and give-away programs } \\ 0 & \text { Loaner Programs }\end{array}$

- Availability

Increasing the availability of low cost helmets requires working with mass merchandiser stores such as $k$-Mart, Sears, and WalMart. Until recently, it had been difficult for many people to find helmets in the large discount department stores where most people buy their bicycles. Helmets were only available in bicycle shops, and then were quite expensive. One factor which helped change this was' when doctors representing the American Academy of Pediatrics met with large discount department store headquarters management to encourage them to stock helmets in their local chain stores. Local demand in certain areas also has played a role in getting these stores to stock helmets.

Bulk purchase and mail order programs discussed later in this section also have contributed to the widespread availability of inexpensive helmets.

\section{- Incentives To Buy}

Another approach to get individuals to obtain a helmet is through discount incentives. Various options include purchases through the use of coupons, bulk orders, mail order, and manufacturer and retail store promotions.

Coupons offering a discount are the most widely used incentive. Coupons have been distributed through schools, retailers, doctor's offices, paycheck envelopes, bike rodeos, and health fairs. The type of coupons have varied from a standard single sheet to those printed in a brochure format, in some cases with brief questionnaires. Using the brochure format offers an opportunity to also educate consumers about helmets, including care and fit, and the effectiveness of helmets to prevent injuries. 
Some coupons offer a set reduced price for the helmet such as Pro-tec's $\$ 26$ coupons good for one of their $\$ 40$ helmets. Others, like coupons for Bell Helmets, offer $\$ 5$ or $\$ 10$ off the regular price. Giro offers a $\$ 20$ trade-in coupon on one of their helmets for children if the child outgrows the helmet.

Promotions in Marietta, GA and Missoula, MT have offered a percentage off the price of any one of several models available at local bike shops. In VA, 250,000 coupons for $\$ 10$ off a Bell helmet were distributed through state agencies, coalition members, schools, the media, and 73 bicycle shops. Four thousand coupons were redeemed between 1989 and 1990 .

Activities can include organizing a bulk purchase through an organization such as a school PTA in order to provide low cost helmets to riders. Bulk purchases have been organized through many groups and organizations. In addition to manufacturers, there are several companies that specialize in bulk purchases, such as Shinn and Associates, American Health and Safety Products, and Ride Safe, that have offered low cost helmets ranging from $\$ 11.95$ to $\$ 25$.

American Automobile Association (AAA) members in OK were given the opportunity to purchase a helmet for $\$ 18.50$. Over 3,000 helmets were sold in two years. The NJ AAA offered its members a 10 percent discount during May 1991 at any one of 15 area bike shops. CareAmerica, a health insurance plan, offered its members a $\$ 20$ helmet. Helmets also have been made available through Miami Children's Hospital, the Bloomington, IL Red Cross Chapter, and through the st. Lukes Hospital Auxiliary, Cedar Rapids, IA.

Helmet sales at "Back to School Nights" sold 314 helmets over a four year period in a town with only $450 \mathrm{~K}-8$ th grade students. A school in Peterborough, NH with 500 students sold 400 helmets to students and 200 to adults. In one area, a woman organized a bulk purchase in her neighborhood so all the children would get helmets at the same time, thus preventing the reluctance of "being the first or only" child to wear a helmet.

American Academy of Pediatrics, CareAmerica, and Johnson \& Johnson, among others, have offered helmets for sale through the mail. For example, Johnson \& Johnson offered a $\$ 9.95$ helmet with proofs of purchase. The offer was included in sunday newspaper advertising supplements in major markets throughout the country. Helmets also are available in bicycle-specialty catalogs.

Most large discount department store chains now stock helmets that range from $\$ 17$ to $\$ 30$. One chain, shopko, has advertised 20 percent off its entire line of helmets several times. The sale prices ranged from $\$ 13.59$ to 22.39 . 
Many promotions reported the distribution of helmets to children from low income families. These programs provided helmets free of charge or used a sliding-scale for the price (often under $\$ 5$ ) to children from low-income families.

A New York Department of Health program provided 150 helmets to a local campaign for giveaways to children from low income families. The community had to provide 75 helmets from local resources. A program through the National Safe Kids Campaign and Bell Helmets offers local Safe Kids coalitions discounted helmets in bulk. In VA, 400 helmets were distributed free to children from low income families who participated in bike rodeos.

Helmets also are given away as part of radio station promotions, poster contest prizes, and free drawings. In Portland, $O R, 90$ helmets were given away, one in each class, in 14 schools. Specialized, a manufacturer of bicycles and helmets sold through bike shops, hass offered a free helmet with the purchase of one of its mountain bike models. The helmets come with a free replacement policy if the helmet was being used and was damaged in a crash.

\section{- Loaner Programs}

Helmets also have been distributed through various types of loaner programs. Often, special bicycling events and programs, such as the Chesterfield Department of Parks and Recreation and the oH Council of the American Youth Hostels, require participants to use helmets and will loan one to those who do not have a helmet. A "Helmet Bank" has been created in Norfolk, VA to loan to bike safety or rodeo programs. A program in Medford, NY loans helmets to individuals, with the option to purchase the helmet over time.

Insurance concerns have resulted in helmets being loaned. For example, most bicycle dealers loan helmets to their customers. Bicycle rental stores sometimes include a helmet in the price of the rental:

Helmet Use Activities

Specific strategies to promote helmet use can be grouped into two general categories, required or mandatory use, and incentives and rewards for wealing a helmet. 
Required helmet use by riders can be part of any bicycling event. Such a requirement can be controversial for organizations, even with some riders who already wear helmets. It was reported in the survey that some organizations, which required helmet use, had members resign.

Helmet use is required when riding to and from school in North Caldwell (NJ). schools, and on many organized rides conducted by such organizations as the American Youth Hostels. Other examples are:
○
All United States Cycling Federation - the governing body of amateur bicycle racing and olympic training, sanctioned events, and training rides, have required their participants to wear a helmet since 1986.
- Bicycle tour operators - such as Bikecentennial which instituted its policy in 1987, often require cycle tourists to wear helmets
- Greater Arizona Bicyclist Association - has required helmets on all its advance registration events since 1988. This move was motivated by concern for liability and the need for an aggressive risk management plan for insurance coverage.
- U.S. Navy - helmet use has been required on government streets, sidewalks and roadways, but is not required in military housing areas where children and families might typically ride.

Several states (CA, NY, PA and MA) have enacted legislation requiring helmet use for young children carried as passengers on bicycles. Other states, and several counties and communities have considered more controversial legislation requiring child cyclists or all cyclists to wear helmets. Currently, two Maryland counties and a municipality in ohio require helmet use for children and/or young adults.

Many organizations and individuals, including the National safe Kids Campaign, advocate that states, or local municipalities enact legislation requiring helmet use. Some advocate mandating helmet use by young children carried as passengers on bicycles. others push for legislation requiring child cyclists or all cyclists to wear helmets. The League of American Wheelmen has supported mandatory use and states its position and other bicyclist concerns in the pamphlet "Helmet Issue Gets Hot: Time to Take Action." 
Incentives and rewards can be used to entice, motivate, and reward helmet users, to both start and reinforce the use habit. some strategies for motivating helmet use among children include using the helmet as a "ticket" for participation in a special event. An ice cream party, or special video showing for helmet users are two ways this has been done. Child helmet wearers participated in a helmet parade and attended a special children's music concert in Peterborough, NH. In Madison, NJ, children with helmets rode in the Memorial Day parade.

Another type of incentive is the use of professional sports teams or other heroes to make helmet use more acceptable among children. In addition, helmet manufacturers have created specifically marketed products with bold colors, exciting designs and popular characters, such as a line of Teenage Mutant Ninja Turtle helmets, for children.

Children "caught" wearing helmets have been rewarded with coupons, certificates and passes for ice cream, french fries, video games, sports events and movies by volunteers, costumed superheros and police officers. In one area, polaroid photographs taken of students wearing helmets as they arrived at school were publicly displayed in the school gym.

Pierce county (WA) Blue Cross and Blue Shield waves the medical deductible for any of their policy holders who are injured while riding a bicycle and wearing a helmet.

\section{SUPPORT}

Campaign Coordinator(s)

A campaign needs a coordinator. The more time the coordinator can spend on the promotion, usually the better. Bicycle helmet campaigns in the early 1980's were primarily spearheaded by individuals involved in bicycling and those motivated by tragedy, such as Bette coan who distributed 10,000 helmets in Palo Alto, CA. Today, bicycle helmets are promoted by a much broader, sometimes diverse group, or coalition, of individuals and organizations, including injury prevention groups, the medical community, health and police departments, PTA's, schools, and hospitals.

A strong network or coalition of a broad base of interested people and organizations coupled with a strong leader, coordinator or organizer has been found to be a key factor in successful promotions. Support is also essential from helmet 
manufacturers, distributors, and bicycle shops. of the promotions surveyed, 75 percent were run by coalitions of two or more organizations. Most were larger, broader community-based coalitions representing bicycle groups, safety, medical, youth, civic, well as school and government agencies.

Some coalitions promoting helmets were formed specifically for this purpose. Others were already organized and working on other issues, but decided to include helmet promotion. For example, several coalitions reported working on other traffic safety issues such as seat belts or child passenger safety and now have included the promotion of bicycle helmets.

The remaining 25 percent of the promotions surveyed were conducted by individuals or single organizations. often individuals have taken a leadership role in response to a tragedy or near tragedy in their own family, neighborhood or community.

In coalition and non-coalition efforts, many campaign organizers or coordinators volunteered their time. Paid staff, if any, were often not specifically paid to conduct the campaign, but were allowed to include helmet promotion in their regular duties.

Funding

An essential element cited by most promotions surveyed was funding, however, several reported successful campaigns with no or very limited funding. Mini-grants and matching fund grants from local organizations, health departments and national organizations supported others. In many of the promotions, funding was primarily used for the purchase or development of program materials.

Two types of funding were reported in the survey, in-kind and actual money. Many sought and found funding in the form of in-kind donations. In-kind donations of goods and services, especially from coalition partners and local business in the community were responsible for most of the bicycle helmet activities done at the local level. Volunteers did the majority of the work, sometimes with paid staff, but often without. Technical assistance, free advertising, merchandise for prizes, printing, and distribution of materials were a few of the other ways helmet campaigns had received in-kind funding.

Money to conduct helmet campaigns was sometimes available through grant programs such as the mini-grants $(\$ 4,000)$ by the American Academy of Pediatrics to members. Mini-grants, of up to $\$ 7,000$, were given to local health departments by the North Carolina Department of Environment, Health and Natural Resources. The National Safe Kids Campaign has given matching grants to its 
local coalitions. Other sources of this type of funding were small donation: (usually well under $\$ 1,000$ ) from local businesses, foundations, civic organizations, and PTA's.

Only about 60 percent of the promotions surveyed reported funding levels for their programs. Those that did, often conducted their programs with little or no money. Approximately 20 percent of the promotions reported having only in-kind donations and volunteer staff: or budgets of less than $\$ 500$ per year.

\section{Technical Assistance}

Materials, operational information, and technical assistance from others have helped stimulate the growth and development of campaigns, and model what can be done and how to do it. Local organizers report that they didn't "have to re-invent the wheel." These efforts served to directly and indirectly aid local promotions and make the community more receptive to specific, targeted campaigns. National recognition of the importance of helmets also smoothed the way for local activities.

The well documented and publicized Harborview campaign in Seattle, WA has encouraged helmet promotion efforts in other communities and by other organizations throughout the country. other campaigns also have made significant contributions toward more helmet promotion activity. The National Safe Kids Campaign has supported the growth and development of over 100 state and local coalitions working to prevent childhood injuries, including promoting bicycle helmet use.

Harborview, Safe Kids, and a number of other organizations have created specific guides or manuals for local campaigns and have held training conferences to support and encourage local activity. Othes organizations that have provided technical assistance include the American Academy of Pediatrics, the National Head Injury Foundation, the Bicycle Federation of America, Bicycle Helmet Safety Institute, New York state Department of Health, Dartmouth, and the NC Department of Transportation. Support came in the form of guides, reproducible or available for purchase materials, conferences, workshops, presentations, advice, referral, and information sharing. Examples are:

- A series of local promotions coordinated by the New York Lepartment of Health (NYDOH) to increase helmet use by children from low income populations. The NYDOH provides helmets for these promotions if local campaigns agree to report monthly progress, conduct evaluations on the distribution and use of helmets, and solicit local community donations to replenish the 
stock of helmets.

- Training sessions have been conducted by several organizations to stimulate and nurture local campaign activity. The North Carolina Department of Transportation sent letters to 1,200 public agencies, schools, and youth and bicycle groups asking them to get involved in helmet promotion. Over 200 agencies and groups responded from 150 different communities. Respondents were invited to Raleigh for a day long workshop and training session. A local campaign resource materials kit was distributed with sample brochures, posters, campaign background information, bike safety resources lists, and helmet discount information.

- Other organizations, such as the Rochester Helmet Coalition, the Cooperative Extension office in Ithaca, NY, and the National Safe Kids Campaign, also have conducted conferences and training sessions.

- "Bicycle Helmet Use Campaign Marketing Study," Bicycle Federation of America for Florida Department of Transportation.

- "Bike Smart Kit," and evaluation materials, American Trauma Society, PA Division.

- "Attitudes Toward Bicycle Helmet Ownership and Use by School-age Children," DiGuiseppi C, Rivara F, Koepsell T. American Journal of Diseases of Children, "1990, $144: 83-86$.

- "Bicycle Helmet Use by Children: Evaluation of a Community-wide Helmet Campaign," DiGuiseppi C, Rivara F, Koepsell T. Journal of the American Medical Association, 1989, 262:2256-2261.

User guides and other specific technical support are listed in Appendix A.

\section{EVALUATION}

Evaluation can be used to determine local needs for the promotion, to provide information needed to determine target activities, and to demonstrate the effectiveness of the activities in meeting identified needs. It should be an integral part of any campaign and includes collecting information and data before, during, and after the program. 
Many local promotions with limited resources find it difficult to design, collect data, and analyze results for an evaluation. From the survey, 76 percent of the promotions reported no evaluation (33\%) or provided few details (43\%). Most of those which reported limited evaluations conducted simple assessments such as tracking the number of discount coupons redeemed.

More comprehensive evaluations with good documentation or more than one measure of effectiveness were reported by those promotions which tended to be larger, more generously funded, and often involved with public heath agencies, hospitals, or universities. For example, Harborview, MI and New York state Departments of Health, and the City of Irvine, CA reported results of comprehensive evaluations.

Evaluations can be defined into two general categories, impact and administrative (or process). Impact measures of a program include awareness and attitude surveys, helmets sold, helmets owned, helmet usage, bicycle-related head injuries, and bicycle-related fatalities.

Impact Evaluation

- Awareness \& Attitude Surveys

Awareness and attitude surveys are often used to determine the reasons for non-use among both non-owners and those who do own helmets. The targets of this type of evaluation are usually parents of school aged children, although the awareness and attitudes of children are often assessed as well.

Surveys can be conducted over the telephone, mailed to individuals, or handed to individuals to be completed at that time or returned at a later time. Most surveys are administered with some form a questionnaire.

For example; in NY, a self-administered questionnaire was used to survey the attitudes of $\mathrm{k}-12 \mathrm{th}$ grade students on wearing a helmet if one were given to them. The highest proportion who said they would wear it were in kindergarten. The proportion decreased steadily by grade to a low of five percent of students in grade 12 who reported they would wear a helmet.

- Helmet Sales

Helmet sales or give-away programs can be monitored through retailers, manufacturers, or distributors. For example, in the seattle, WA area, the number of helmets sold by Pro-tec increased 
from 1,500 helmets per year to over 30,000 per year in a four year period.

Another impact measure of a program is to determine the number of discount coupons redeemed for a helmet purchase. The White clay Bicycle Club in Delaware took this process one step further and included three questions on their coupon. From the responses, it was learned that over 80 percent of the 180 people who purchased helmets with the coupons were first time helmet buyers.

- Helmet Ownership

Helmet ownership is most often assessed through some means of self-reporting. The NY Department of Health found 15 percent of $28,000 \mathrm{~K}-12$ th graders surveyed reported owning helmets in 1989 . That number increased to 17 percent in 1990. Reported child helmet ownership data is often collected from a parent.

- Helmet Usage

Helmet usage can be determined either through self-reports, direct observations, or information obtained from hospital emergency rooms. Self-reports are easy and inexpensive to collect, but this method has its limitations. It is well established that individuals consistently over-report usage of safety devices. The procedure is fairly accurate in determining changes in reported usage from one time period to another, but may not be very accurate in determining the actual number of individuals using helmets at any particular time.

The most accurate way to determine helmet use is through direct observations, however care must be taken to insure a representative sample. Weather, time of year, time of day, day of week, and location can influence results. To obtain an accurate estimate of usage, observations should be taken over time at a number of sites, and then repeated at some future date.

Another means of tracking helmet usage involves checking emergency room or hospital files for injured cyclists to determine how many were wearing a helmet at the time of the fall or crash. Access to this information is often not available. Besides a possible access problem, the procedures major problem is that the data is limited. It does not include information from visits to private doctors or clinics or for those who were not injured in a crash. This results in an under-reporting of a promotions impact. 
To assess the influence of a helmet campaign on the number of bicycle-related head injuries seen in emergency room visits and hospital admissions can require more time and does require a much larger bicycle riding population than the other types of evaluation measures discussed above. Most campaigns will not have the resources to conduct this type of evaluation. One that does is Harborview Medical Center, which reported a 50 percent decrease in bicycle-related head injuries since 1986.

Another use of hospital data is to target locations where individuals may be at increased risk of a crash. For example, the Alabama Safe Kids Coalition used injury crash information prior to the start of their campaign. Hospital discharge summaries provided $z i p$ code areas where riders were most at risk and the project then targeted these areas with the promotion. This process is becoming easier as more hospitals are collecting this type of data (i.e., E-codes, or external factor codes).

Again, the issue of under-reporting, as explained above, could be a problem when evaluating any change in head injuries due to a campaign, or using this information to design a campaign.

\section{- Bicycle-Related Fatalities}

The most difficult evaluation impact measure to use is to determine any change in fatalities. For most campaigns, tracking bicycle-related fatalities for. their area may not be appropriate or even possible.

The number of bicycle-related fatalities is quite small, even over several years, in many areas that would have a campaign. This causes major problems in the use of this type of evaluation measure. First, as the number of fatalities are so small, any change in numbers can cause dramatic changes on paper that may not accurately reflect the influence of a helmet campaign. second, the measure requires a much larger population and more time in order to assess campaign effectiveness, often requiring tracking data for several years. The longer the time period needed for an evaluation, the greater the chance that other factors will be the cause of a change in the outcome measure, other than that of the helmet promotion.

Process Evaluation

Process, or administrative evaluations do not track changes in the behavior (e.g., helmet use) of the target group, but rather attempt to determine the effectiveness of the campaign process or 
delivery system. Data for process evaluations are normally much easier to collect and to analyze than are the data needed for an impact evaluation. Examples from the survey include:

- Number of children or adults attending a presentation The White clay Bicycle club made presentations to 6,300 3 rd and 4 th grade students at 26 DE schools.

- Number of materials distributed - DC Department of Public Works distributed over 17,000 "Buckle Up Your Baby" brochures the first year they were available.

- Number of coupons distributed - over 150,000 discount helmet coupons were distributed by Fred Meyer stores in Portland, OR.

- Number of children or adults reached by PSA's on TV or radio - a National Safe Kids Campaign PSA was broadcast nationally on $A B C$, CBS, and $C N N$ to an estimated 515 million households.

- Number of times a PSA aired and its placement in the broadcast schedule - helmet PSA's ran 50 times in a four month period and in every third televised Mariners game in Seattle, WA.

- Number of newspaper or magazine articles published nearly 40 newspaper articles were published during the campaign in Pitt County, NC.

- Number of health care providers who report including helmet information in their patient counseling sessions - in seattle, WA, 180 doctors, hospitals, clinics, and others counseled their patients, and distributed brochures and discount coupons. 


\section{CONCLUSIONS}

Bicycle helmet: promotions have come a long way in the last ten years. Much has been learned and done by many individuals and different types of organizations, and often with few cash resources. There is now a foundation of technical information and materials, such as research establishing the efficacy of helmets, a body of "how to" guides and manuals for promoting the use of helmets, and informational and educational materials for reaching various target audiences. Past campaigns have established a base of credibility and legitimacy for using helmets, and in some areas of the country, there is a strong base of helmet use among some groups.

The challenge now is to fine tune the means of identifying and reaching target audiences, to develop more effective programs to increase helmet use, to better disseminate program information and results, and to encourage more local promotions. There also is the need to design and conduct better evaluations of bicycle helmet promotions.

CONCLUSION 1: Community-based, diverse coalition approach works well for local campaigns

Nearly 75 percent of the promotions reviewed were coordinated or otherwise supported by some type of coalition. Several reported having been started by a single individual or organization that later grew into a partnership of two or more organizations. others began as coalition efforts. Many report the added benefits of a coalition approach in getting work funded and done, giving credibility to the campaign and in reinforcing campaign messages, and building a broad reaching delivery network.

Broad-based coalitions representing safety, health care, bicycling, public health, civic groups, corporations, media, schools and local government can help achieve the objectives of a bicycle promotion. Whenever possible, promotions should take advantage of existing coalitions, task forces, and networks created for other safety or health initiatives. However, even with a coalition, it is very importance to still have an identified coalition leader.

CONCLUSION 2: Health care providers are important to disseminate information and encourage helmet use.

Many promotions have found that health care providers are very effective in delivering helmet messages. Health care providers, 
especially physicians, are generally seen by the public as a source of accurate information. By designing programs and materials for use by this group, campaigns are able to reach a broad spectrum of target audiences. Health care providers often can be identified and reached through professional associations.

CONCLUSION 3: Better evaluations are needed for helmet promotion campaigns.

Only 18 percent of the promotions surveyed operated with a budget of more than $\$ 5,000$ per year. Those operating with little or no funding often devoted very little effort for evaluation. With scarce funding available for injury prevention efforts, it is difficult to secure additional funding without some means of determining local needs, targeting interventions, and demonstrating the effectiveness of the interventions in meeting those needs. Evaluations provide this type of information.

Local baseline data is an important part of identifying local needs, strategies, and target audiences. Target groups that are at risk or are not adequately being addressed by current promotion activities, such as people from low income families, or middle school, high school, and college students can be identified. Baseline data also is needed to compare to later data for determining program effectiveness. Types of data that can be used in an evaluation includes bicycle injuries (sometimes available from police accident reports), helmet sales, and helmet use. Much of this information may not exist at the local level or may not exist in an easily obtainable form, especially for grassroots promotion organizers. However, it must be collected, and it can be done.

One type of data that should be collected is to conduct observations of helmet use before, at periodic intervals during, and after the intervention to track changing helmet use. Subsequent surveys can help determine sustained usage rates and track changes in these rates over longer time periods.

CONCLUSION 4: There is a need to widely disseminate simple, inexpensive- to-implement evaluation methodologies

Models have been developed to evaluate bicycle helmet promotions, and specific "how to" information has been published by various organizations. The importance of evaluation and the means to do so should be widely distributed. For example, "Method for Evaluation of Bicycle Helmet Projects" developed by the NY Department of Health includes detailed instructions for conducting an evaluation. This booklet includes instructions for conducting self-reported classroom surveys, helmet usage observations, instructions for analyzing the results, and 
limitations of: the procedures.

CONCLUSION 5: Additional research is needed to identify successful campaign components.

Research, such as that currently being conducted in FL by Dunlap and Associates, can help better identify the level of promotion and the comporients needed to make changes in helmet use at the local level. To further understand this process, additional research is necessary to determine the various factors which may influence the implementation of these research findings. For instance, the starting level of usage of $0 \%$ may require a different set of strategies, activities, and materials than in a community that currently has $15 \%$ use. The results should be disseminated to a broad spectrum of fields such as health care, public health, bicycling, education, public safety, and law enforcement.

In addition, the reasons that helmets are not being used, especially among the hardest to reach targets, those most at risk, and those still unswayed after exposure to helmet campaigns, should be studied. As more and more riders use helmets, those who do not are generally harder to convince of the importance of using a helmet. Critical populations include males, especially those over 14 years old, adults 25 to 39 years old, and parents. 


\title{
APPENDICES
}

\author{
A: "How To" Promotion Guides and other support \\ B: Local Resources \\ c: Governor's Highway safety \\ Representatives and Coordinators \\ D: Directory of National organizations \\ E: Directory of Promotions \\ F: Directory of state Bicycle and Pedestrian \\ Coordinators \\ G: Sample Survey
}




\section{APPENDIX A}

"How To" Promotion Guides and other support

The following list highlights some of the materials available to encourage and support local helmet campaigns. The list is not exhaustive. See directory listings for full contact information.

General support:

- "AAP Bicycle Safety Resource Guide," AAP NH Chapter, Dartmouth-Hitchcock Medical Center, Hanover, NH 603/646-7780.

- "Bike Helmet and Bike Safety strategy," plus various other publications, National Safe Kids Campaign, Washington, DC 202/939-4993.

o "Bike Helmets for Children" Cooperative Extension, Ithaca, NY 607/255-2498.

- "Community Program Guide," National Head Injury Foundation, Washington, DC 202/296-6443.

- "Guidelines for Establishing Community-Based helmet-Injury Control Projects for Children," NY Department of Health, Albany, NY 518/473-1143.

- "How to conduct a Bicycle Helmet Campaign in Your Community," CT Childhood Injury Prevention Center, Hartford, CT 203/524-3003.

- "How to Have a Bicycle Safety Campaign in Your Community Kit," Solono county Bicycle Safety Campaign, Fairfield, CA 707/422-1040.

- "Increasing Bicycle Helmet Use in Michigan," MI Department of Health, Lansing, MI 517/335-8398.

- "The North Carolina Bicycle Helmet Campaign Guide," in NC: NC Department of Transportation, Raleigh, NC 919/733-2804; in other states: Bikecentennial, Missoula, MT $406 / 721-1776$.

- Documentation Center, Bicycle Helmet Safety Institute (BHSI), Arlington, VA 703/486-0100.

- "Ride Safe Bicycle Helmet Program Guide," Ride Safe, Wheaton, IL 800/285-RIDE. 
- "Study of Bicycle Helmet Ownership \& Usage Among Elementary School Children," Laura Searcy, Marietta, GA. Copies available through BHSI, Arlington, VA 703/486-0100.

- "Use Yous Head: Wear a Helmet," League of American Wheelmen, Baltimore, MD 301/539-3399.

- "The 1990 Washington Children's Bicycle Helmet Campaign," Harborview Injury Prevention \& Research Center, Seattle, WA 206/223-3399.

Evaluation

- "Methods for Evaluation of Bicycle Helmet Projects: A Manual for Local Projects," classroom and observation surveys, NY Department of Health, Albany, NY $518 / 473-1.143$.

- "Pitt County Telephone Survey of Bicycle Helmet Use," NC Department of Environment, Health and Natural Resources, Raleigh, NC 919/733-3816.

- See also Harborview and Searcy work noted above. 


\section{APPENDIX B}

\section{Local Resources}

The following are examples of organizations and agencies in your state and community that often offer support, further

information, local contacts, or will be coalition partners.

STATE AND LOCAL GOVERNMENT

- State and local Departments of Health, especially the Division of Maternal and Child Health

- Law enforcement agencies

- Bicycle programs, bicycle coordinators, bicycle advisory boards or committees

- Parks and recreation departments

- Fire department

- Governor's Highway Safety Representative, check with your governor's office

- State or metropolitan Department of Transportation and/or Department of Highway safety

- Elected officials

- county Extension Service

\section{SAFETY AND INJURY PREVENTION ORGANIZATIONS}

- American Automobile Association chapters

- American Trauma Society chapters

- Safety Council chapters

- Bicycle Federation of America

- National Safe Kids Campaign and local Safe Kids coalitions 


\section{BICYCLE-RELATED ORGANIZATIONS}

- Bicycle shops

- Local mass merchandisers who sell bicycles (e.g., sears, K-Mart, Wal-Mart, Toys-R-Us)

- Bicycle clubs and advocacy organizations

- Helmet manufacturers

- Bulk purchase helmet distributors

- Americar Youth Hostels local councils

- Bikecentennial

- Bicycle Federation of America

- League of American Wheelmen

\section{MEDICAL AND REHABILATATION ORGANIZATIONS \& FACILITIES}

- Local pediatricians, family practioners, nurse practioners, EMT's, nurses, physician's assistants

- Medical associations, especially state chapters of the American Academy of Pediatrics, Emergency Medical Services

- Local hospitals, medical centers, injury control centers

- Rehabilation facilities, organizations and programs

- National Head Injury Foundation chapters

\section{SCHOOLS}

- PTA/PTO's

- State Department of Education, Local Board of Education

- Teachers and school administrators

- Student organizations, especially safety oriented groups

- School nurses 
CIVIC ORGANIZATIONS

- Kiwanis

o optimists

- Women's clubs

- Junior League

- Rotary

YOUTH GROUPS

- Boy Scouts, Girl scouts

○ $4-\mathrm{H}$

- YMCA/YWCA programs

\section{INSURANCE}

o HMO's, health insurance providers

- Life and other insurance companies

- Reinsurance companies

\section{OTHERS}

- Association of Retarded citizens chapters, and other disabilities groups

- Local corporations and businesses

- Church groups

- Sports teams

- Local media, including on-air staff 


\section{GOVERNORS' HIGIIWA Y SAFETY REPRESENTATIVES \& COORDINATORS JANUARY 1993}

\begin{tabular}{|c|c|c|}
\hline GOVERNOR & GOV'S REPRESENTATIVE & COORDINATOR \\
\hline $\begin{array}{l}\text { Alabama } \\
\text { Gov. Harold Guy Hunt (R) } \\
\text { State House } \\
\text { Montgomery, AL } 36130 \\
\text { Phone: } 205 / 261-3592\end{array}$ & $\begin{array}{l}\text { Gene Anderson } \\
\text { Dept. of Econ. \& Comm. } \\
\text { Affairs } \\
\text { *P.O.Box 5690, } 401 \text { Adams Ave. } \\
\text { Montgomery, AL } 36103-5690 \\
\text { Phone: } 205 / 242-8672 \\
\text { Fax: 205/242-5515 }\end{array}$ & $\begin{array}{l}\text { James Quinn, Div. Chicf } \\
\text { Traffic Safety Section } \\
\text { Dept. of Econ. \& Comm. Affairs } \\
\text { *P.O.Box 5690, 401 Adams Ave. } \\
\text { Montgomery, AL } 36103-5690 \\
\text { Phone: } 205 / 242-5897 \\
\text { Fax: 205/242-5515 }\end{array}$ \\
\hline $\begin{array}{l}\text { Alaska } \\
\text { Gov. Walter J. Hickel (I) } \\
\text { P. O. Box A } \\
\text { Juneau, AK } 99811 \\
\text { Phone: } 907 / 465-3500\end{array}$ & $\begin{array}{l}\text { Richard Burton, Dep.Commissioner } \\
\text { Dept. of Public Safety } \\
\text { Highway Saf. Planning Agency } \\
\text { *P.O. Box 1112000, 450 Whittier St. } \\
\text { Juneau, AK } 99811 \\
\text { Phone: } 907 / 465-4322 \\
\text { Fax: } 907 / 465-4362 \\
\end{array}$ & SAME \\
\hline $\begin{array}{l}\text { Arizona } \\
\text { Gov. Fife Symington (R) } \\
\text { State House } \\
\text { Phoenix, AZ 85007 } \\
\text { Phone: } 602 / 255-4331\end{array}$ & $\begin{array}{l}\text { R. J. "Rick" Ayars, Director } \\
\text { Dept. of Public Safety } \\
\text { Gov's Office of Hwy Safety } \\
3010 \text { N. Second St., Suite } \# 104 \\
\text { Phoenix, AZ } 85012 \\
\text { Phone: } 602 / 223-2359 \\
\text { Fax: } 602 / 223-2917 \\
\end{array}$ & $\begin{array}{l}\text { Howard Adams } \\
\text { Gov's Office of Hwy Saf. } \\
3010 \text { N. Second St., Suite } \sharp 105 \\
\text { Phoenix, AZ } 85012 \\
\text { Phone: } 602 / 255-3216 \\
\text { Fax: } 602 / 255-1265\end{array}$ \\
\hline $\begin{array}{l}\text { Arkansas } \\
\text { Gov. Jim Guy Tucker (D) } \\
\text { State Capitol } \\
\text { Little Rock, AR } 72201 \\
\text { Phone: } 501 / 371-2345\end{array}$ & $\begin{array}{l}\text { Maurice Snith, Director } \\
\text { AR State Hwy \& Trans Dept } \\
11300 \text { Baseline Rd. } \\
\text { Little Rock, AR } 72209 \\
\text { Phone: } 501 / 569-2648 \\
\text { Fax: } 501 / 569-2400\end{array}$ & $\begin{array}{l}\text { Mike Selig, Chief } \\
\text { Traffic Safety Seclion } \\
\text { AR State Hwy \& Trans Dept. } \\
\text { *P.O.Box } 226 \\
\text { Little Rock, AR } 72209 \\
\text { Phone: } 501 / 569-2231 \\
\text { Fax: } 501 / 455-1978 \\
\end{array}$ \\
\hline
\end{tabular}




\begin{tabular}{|c|c|c|}
\hline GOVERNOR & GOV'S REPRESENTATIVE & COORDINATOR \\
\hline $\begin{array}{l}\text { California } \\
\text { Gov. Pele Wilson (R) } \\
\text { State Capitol, Sacramento } 95814 \\
\text { Phone: } 916-445-2841\end{array}$ & $\begin{array}{l}\text { Pele K. O'Rourke, Director } \\
\text { Office of Traffic Safety } \\
\text { Business, Transportation, } \\
\text { and Housing Agency } \\
7000 \text { Franklin Blvd., Suite } 440 \\
\text { Sacramenlo, CA } 95823 \\
\text { Phone: } 916-445-0527 \\
\text { Fax: } 916-324-9606\end{array}$ & $\begin{array}{l}\text { Ray Biancalana, Asst. Director } \\
\text { Office of Traffic Safety } \\
\text { Business, Transportation, } \\
\text { and Housing Agency } \\
7000 \text { Franklin Blvd., Suile } 440 \\
\text { Sacramento, CA } 95823 \\
\text { Phone: } 916-445-0527 \\
\text { Fax: 916-324-9606 }\end{array}$ \\
\hline $\begin{array}{l}\text { Colorado } \\
\text { Gov. Roy Romer (D) } \\
\text { State Capitol, Denver } 80203 \\
\text { Phone: } 303-866-2471\end{array}$ & $\begin{array}{l}\text { Dwight M. Bower, Exec. Director } \\
\text { Colorado Dept. of Transportation } \\
4201 \text { East Arkansas Ave. } \\
\text { Denver, CO } 80222 \\
\text { Phone: } 303-757-9201 \\
\text { Fax: } 303-757-9153\end{array}$ & $\begin{array}{l}\text { John Conger, Direcior } \\
\text { Office of Transportation Safety } \\
\text { Colo. DOT } 4201 \text { E. Arkansas Ave. } \\
\text { Denver, CO } 80222 \\
\text { Phone: } 303-757-9440 \\
\text { Fax: } 303-757-9439\end{array}$ \\
\hline $\begin{array}{l}\text { Counecticut } \\
\text { Gov. Lowell P. Weicker, Jr. (I) } \\
\text { State Capitol, Hartford } 06106 \\
\text { Phone: } 203-566-4840\end{array}$ & $\begin{array}{l}\text { Susan C. Maloney, Gov's Rep. } \\
\text { Bureau of Highways } \\
\text { *P.O. Box Drawer A } \\
\text { Wethersfield, CT 06109-0801 } \\
\text { Phone: } 203 / 666-4343 \\
\text { Fax: 203/666-1270 }\end{array}$ & SAME \\
\hline $\begin{array}{l}\text { Delaware } \\
\text { Gov. Tom Carper (D) } \\
\text { Legislative Hall, Dover } 19901 \\
\text { Phone: } 302-736-4101\end{array}$ & $\begin{array}{l}\text { Colonel Clifford M. Graviet } \\
\text { Delaware State Police } \\
\text { P.O. Box } 430 \\
\text { Dover, DE } 19901 \\
\text { Phone: } 302-739-5911 \\
\text { Fax: } 302-739-5966\end{array}$ & $\begin{array}{l}\text { Lt. Paul Stafford, Director } \\
\text { Delaware State Police } \\
\text { P. O. Box } 430 \\
\text { Dover, DE } 19901 \\
\text { Phone: 302-739-5613 } \\
\text { Fax: 302-739-5995 }\end{array}$ \\
\hline
\end{tabular}




\begin{tabular}{|c|c|c|}
\hline GOVIERNOR & GOV'S REPRESENTATIVE & COORDINATOR \\
\hline $\begin{array}{l}\text { District of Columbia } \\
\text { Mayor Sharon Pratt-Kelly (D) } \\
\text { Suite 520, District Building } \\
\text { Washington DC } 20004 \\
\text { Phone: 202/727-6319 }\end{array}$ & $\begin{array}{l}\text { Esther Hager Francis, Director } \\
\text { Department of Public Works } \\
\text { Frank D. Reeves Center } \\
2000 \text { 14th St., NW, 6th Floor } \\
\text { Washington, DC } 20009 \\
\text { Phone: 202-939-8000 } \\
\text { Fax: 202-939-8191 } \\
\end{array}$ & $\begin{array}{l}\text { Carolc A. Lewis, Chicf } \\
\text { Transportation Safely Branch } \\
\text { Department of Public Works } \\
200014 \text { th St., NW, 7th Floor } \\
\text { Washington, DC } 20009 \\
\text { Phone: 202-939-8018 } \\
\text { Fax: 202-939-7185 }\end{array}$ \\
\hline $\begin{array}{l}\text { Florida } \\
\text { Gov. Lawton Chiles (D) } \\
\text { State Capitol, Tallahassee } 32399 \\
\text { Phone: } 904-488-2272\end{array}$ & $\begin{array}{l}\text { Frank Carlile } \\
\text { Asst. Sec. for Trans. Policy } \\
\text { Governor's Hwy.Safety Rep. } \\
\text { Department of Transportation } \\
\text { 605 Suwanne Strcet, MS-57 } \\
\text { Tallahassee, Florida 32399-0450 } \\
\text { Phone: (904) } 922-5820 \\
\text { Fax: (904) 922-2935 }\end{array}$ & $\begin{array}{l}\text { G. Ed Rice } \\
\text { State Safety Engineer } \\
\text { Dept. of Transportation } \\
\text { 605 Suwanne Street, MS-53 } \\
\text { Tallahassee, FL } 32399-0450 \\
\text { Phone: (904) } 488-3546 \\
\text { Fax: (904) 922-2935 } \\
\quad \text { (cc John Ward at same address } \\
\text { as above, mail code MS-17) }\end{array}$ \\
\hline $\begin{array}{l}\text { Georgia } \\
\text { Gov. Zell Miller (D) } \\
\text { State Capitol, Atlanta } 30334 \\
\text { Phone: } 404-656-1776\end{array}$ & $\begin{array}{l}\text { Dr. Thomas L. Coleman, Ed.D } \\
\text { Dir., Gov.'s Office of Hwy. Safely } \\
\text { The Equitable Building } \\
100 \text { Peachtree Street, Suite } 2000 \\
\text { Atlanta, GA } 30303 \\
\text { Phone: } 404-656-6996 \\
\text { Fax: 404-651-9107 }\end{array}$ & SAME \\
\hline
\end{tabular}




\begin{tabular}{|c|c|c|}
\hline GOVERNOIR & GOV'S REPRESENTA'TIVE & COORDINATOR \\
\hline $\begin{array}{l}\text { IIawaii } \\
\text { Gov. John Waihee III (D) } \\
\text { State Capitol, Honolulu } 96813 \\
\text { Phonc: } 808-548-5420\end{array}$ & $\begin{array}{l}\text { Rex D. Joluson } \\
\text { Director of Transportation } \\
\text { Governor's Hwy. Safely Rep. } \\
869 \text { Punchbowl Street } \\
\text { Honolulu, HI } 96813 \\
\text { Phone: } 808-587-2150 \\
\text { Fax: } 808-587-2167 \\
\end{array}$ & $\begin{array}{l}\text { Larry K. Hao, Administrator } \\
\text { Motor Vchicle Safety Office } \\
\text { Department of Transportation } \\
\text { 1505 Dillingham Blvd., Rm } 214 \\
\text { Honolulu, HI } 96817 \\
\text { Phone: } 808-832-5820 \\
\text { Fax: } 808-832-5830 \\
\end{array}$ \\
\hline $\begin{array}{l}\text { Idaho } \\
\text { Gov. Cecil D. Andrus (D) } \\
\text { State Capitol, Boise } 83720 \\
\text { Phone: } 208-334-2547\end{array}$ & $\begin{array}{l}\text { Marc Johnson } \\
\text { Governor's Iwy. Safely Rep. } \\
\text { Governor's Office } \\
\text { Slate House Mail } \\
\text { Boise, ID } 83720 \\
\text { Phone: } 208-334-2100 \\
\text { Fax: 208-334-3858 }\end{array}$ & $\begin{array}{l}\text { Marie Bishop, Coordinator } \\
\text { Office of Highway Safety } \\
\text { Department of Transportation } \\
\text { *P.O. Box } 7129 \\
\text { 3311 West State Street } \\
\text { Boise, ID } 83707 \\
\text { Phone: 208-334-8101 } \\
\text { Fax: 208-334-3858 }\end{array}$ \\
\hline $\begin{array}{l}\text { Illinois } \\
\text { Gov. Jim Edgar (R) } \\
\text { State Capitol, Springfield } 62706 \\
\text { Phone: } 217-782-6830\end{array}$ & $\begin{array}{l}\text { Gary D. March, Director } \\
\text { Division of Traffic Safety } \\
\text { Department of Transportation } \\
\text { *P.O. Box } 19245 \\
\text { 3215 Executive Park Drive } \\
\text { Springfield, IL } 62794-9245 \\
\text { Phone: } 217-782-4972 \\
\text { Fax: 217-782-9159 }\end{array}$ & $\begin{array}{l}\text { Larry Wort, Chief } \\
\text { Bureau of Safety Programs } \\
\text { Department of Transportation } \\
\text { *P.O. Box 19245 } \\
\text { 3215 Execulive Park Drive } \\
\text { Springficld, IL } 62794-9245 \\
\text { Phone: 217-782-4974 } \\
\text { Fax: 217-782-9159 }\end{array}$ \\
\hline $\begin{array}{l}\text { Indiana } \\
\text { Gov. Evan Bayh (D) } \\
\text { State House, Indianapolis } 46204 \\
\text { Phone: } 317-232-4567\end{array}$ & $\begin{array}{l}\text { Bobby Small } \\
\text { Governnor's Representative } \\
\text { for Highway Safety } \\
\text { Room 206, State House } \\
\text { Indianapolis, IN } 46204 \\
\text { Phone: 317-232-2588 } \\
\text { Fax: 317-232-3443 }\end{array}$ & $\begin{array}{l}\text { Ann Reiter, Director } \\
\text { Office of Traffic Safely } \\
\text { ISTA Builing, Suite } 330 \\
\text { 150 W. Market } \\
\text { Indianapolis, IN } 46204 \\
\text { Phone: } 317-233-1287 \\
\text { Fax: } 317-233-5150\end{array}$ \\
\hline
\end{tabular}




\begin{tabular}{|c|c|c|}
\hline GOVERNOR & GOV'S REPRESENTATIVE & COORDINATOR \\
\hline $\begin{array}{l}\text { Iowa } \\
\text { Gov. Terry E. Branstad (R) } \\
\text { State Capitol, Des Moines } 50319 \\
\text { Phone: 515-281-5211 }\end{array}$ & $\begin{array}{l}\text { Paul II. Wieck, II, Commissioner } \\
\text { Iowa Dept. of Public Safety } \\
\text { Wallace State Office Building } \\
\text { Des Moines, IA } 50319 \\
\text { Phone: 515-281-5104 }\end{array}$ & $\begin{array}{l}\text { J. Micliacl Laski, Director } \\
\text { Governor's Traffic Safety Bureau } \\
307 \text { East 7th St. } \\
\text { Des Moines, IA 50319-0248 } \\
\text { Phone: } 515-281-3907 \\
\text { Fax: } 515-281-6190\end{array}$ \\
\hline $\begin{array}{l}\text { Kansas } \\
\text { Gov. Joan Finney (D) } \\
\text { State Capitol Bldg., } \\
\text { Topeka KS 66603 } \\
\text { Phone: } 913-296-3232\end{array}$ & $\begin{array}{l}\text { Michael Johnston, Secretary } \\
\text { Department of Transporlation } \\
\text { Docking St. Bldg., 7th Floor } \\
\text { Topeka, KS 66612-1568 } \\
\text { Phone: 913-296-3461 }\end{array}$ & $\begin{array}{l}\text { Rosalic Thornburgh, Administralor } \\
\text { Office of Traffic Safety } \\
\text { Thacker Building, 2nd Floor } \\
217 \text { SE 4th Street } \\
\text { Topeka, KS } 66603 \\
\text { Phone: } 913-296-3756 \\
\text { Fax: } 913-296-0963\end{array}$ \\
\hline $\begin{array}{l}\text { Kentucky } \\
\text { Gov. Brereton C. Jones (D) } \\
\text { State Capitol, Frankfort 40601 } \\
\text { Phonc: 502-564-2611 }\end{array}$ & $\begin{array}{l}\text { Billy G. Wellman, Sec. of St.Police } \\
\text { Kenlucky State Police Headquarters } \\
919 \text { Versailles Road } \\
\text { Frankfort, KY } 40601-9980 \\
\text { Phone: 502-695-6300 } \\
\text { Fax: 502-564-6615 }\end{array}$ & $\begin{array}{l}\text { David H. Salyers, Commander } \\
\text { Highway Safety Branch } \\
\text { KY State Police Headquarters } \\
919 \text { Versailles Road } \\
\text { Frankfort, KY 40601-9980 } \\
\text { Phone: 502-695-6356 } \\
\text { Fax: 502-564-6615 }\end{array}$ \\
\hline $\begin{array}{l}\text { Louisana } \\
\text { Gov. Edwin Edwards (D) } \\
\text { P.O. Box 94004, } \\
\text { Baton Rouge 70804 } \\
\text { Phone: 504-342-7015 }\end{array}$ & $\begin{array}{l}\text { Belle S. Theis, Exec. Dir. } \\
\text { Highway Safely Commission } \\
\text { P.O. Box 66336 } \\
\text { Baton Rouge, LA } 70896 \\
\text { Phone: 504-925-6991 } \\
\text { Fax: 504-925-6846 }\end{array}$ & $\begin{array}{l}\text { Sue Dixon, Asst. Director } \\
\text { Highway Safety Commission } \\
\text { P.O. Box 66336 } \\
\text { Baton Rouge, LA } 70896 \\
\text { Phone: 504-925-6846 } \\
\text { Fax: 504-922-0083 } \\
\end{array}$ \\
\hline
\end{tabular}




\begin{tabular}{|c|c|c|}
\hline GOVERNOR & GOV'S REPRESENTATIVE & COORDINATOR \\
\hline $\begin{array}{l}\text { Maine } \\
\text { Gov. John R. McKernan, Jr. (R) } \\
\text { State House, Augusta } 04333 \\
\text { Phone: } 207-289-3531\end{array}$ & $\begin{array}{l}\text { Richard E. Perkins, Director } \\
\text { Burcau of Safely } \\
\text { Department of Public Safety } \\
\text { *36 Hospital Street } \\
\text { State House Station } \$ 42 \\
\text { Augusta, ME } 04333 \\
\text { Phone: } 207-582-8776\end{array}$ & SAME \\
\hline $\begin{array}{l}\text { Maryland } \\
\text { Gov. William Donald Schaeffer (D) } \\
\text { State House, Annapolis } 21401 \\
\text { Phone: } 410-269-3901\end{array}$ & $\begin{array}{l}\text { Hal Kassoff, Administrator } \\
\text { State Highway Administration } \\
707 \text { N. Calvert St. } \\
\text { Baltimore, MD 21203-0717 } \\
\text { Phone: 410-333-1111 }\end{array}$ & $\begin{array}{l}\text { Dennis R. Atkins, Asst.Director } \\
\text { Office of Traffic and Safety } \\
\text { 7491 Connelley Dr. } \\
\text { Baltimore, MD } 21076 \\
\text { Phone: } 410 / 787-7697 \\
\text { Fax: } 410 / 553-6399\end{array}$ \\
\hline $\begin{array}{l}\text { Massachusetts } \\
\text { Gov. William F. Weld (R) } \\
\text { State House, Boston } 02133 \\
\text { Phone: } 617-727-3600\end{array}$ & $\begin{array}{l}\text { Nancy J. Luther, Director } \\
\text { Governor's Highway Safety Bureau } \\
100 \text { Cambridge St., Room } 2104 \\
\text { Saltonstall State Office Bldg. } \\
\text { Boston, MA 02202 } \\
\text { Phone: } 617-727-5073 \\
\text { Fax: } 617-727-5077 \\
\end{array}$ & SAME \\
\hline $\begin{array}{l}\text { Michigan } \\
\text { Gov. John Engler (R) } \\
\text { State Capitol, Lansing } 48909 \\
\text { Phone: } 517-373-3400\end{array}$ & $\begin{array}{l}\text { Belly Mercer, Exec. Direclor } \\
\text { Office of Hwy. Safely Planning } \\
300 \text { South Washington Square } \\
\text { Knapps Center, Suite } 300 \\
\text { Lansing, MI 48913 } \\
\text { Phone: } 517-334-5210 \\
\text { Fax: 517-482-8236 } \\
\end{array}$ & SAME \\
\hline
\end{tabular}




\begin{tabular}{|c|c|c|}
\hline GOVERNOR & GOV'S REPRESENTATIVE & COORDINATOR \\
\hline $\begin{array}{l}\text { Minnesota } \\
\text {.Gov. Arne Carlson (R) } \\
\text { State Capitol, SI. Paul } 55155 \\
\text { Phone: } 612-296-3391\end{array}$ & $\begin{array}{l}\text { Michacl S. Jordan, Commissioner } \\
\text { Department of Public Safety } \\
\text { 211 Transportation Building } \\
\text { St. Paul MN 55155 } \\
\text { Phone: } 612-296-6642 \\
\text { Fax: } 612-297-5728 \\
\end{array}$ & $\begin{array}{l}\text { Thomas A. Boerner, Director } \\
\text { Office of Traffic Safety } \\
211 \text { Transp. Building, Room } 207 \\
\text { St. Paul MN 55155 } \\
\text { Phone: 612-296-3804 } \\
\text { Fax: 612-297-5728 }\end{array}$ \\
\hline $\begin{array}{l}\text { Mississippi } \\
\text { Gov. Kirk Fordice (R) } \\
\text { P.O. Box 139, Jackson } 39205 \\
\text { Phone: } 601-359-3100\end{array}$ & $\begin{array}{l}\text { Donald O'Cain, Director } \\
\text { Governor's Hwy. Safety Programs } \\
\text { MS Deprtment of Public Safely } \\
301 \text { West Pearl Street } \\
\text { Jackson, MS 39203-3085 } \\
\text { Phone: 601-949-2225 } \\
\text { Fax: 601-960-4263 } \\
\end{array}$ & SAME \\
\hline $\begin{array}{l}\text { Missouri } \\
\text { Gov. Mel Carnalıan (D) } \\
\text { State Capitol, } \\
\text { Jefferson City, MO } 65101 \\
\text { Phone: } 314-751-3222\end{array}$ & $\begin{array}{l}\text { Arvid E. West, Jr., Director } \\
\text { Div. of Hwy. Safety } \\
\text { Dept. Of Public Safety } \\
\text { *P.O. Box } 104808 \\
\text { 1719 Southridge Drive } \\
\text { Jefferson City, MO } 65110-4804 \\
\text { Phone: } 314-751-4161 \\
\text { Fax: } 314-634-5977 \\
\end{array}$ & SAME \\
\hline $\begin{array}{l}\text { Montana } \\
\text { Gov. Marc Racicot (R) } \\
\text { State Capitol, Helena } 59620 \\
\text { Phone: } 406-444-3111\end{array}$ & $\begin{array}{l}\text { Albert E. Goke, Administrator } \\
\text { Highway Traffic Safely Division } \\
1310 \text { East Lockey } \\
\text { State Capitol } \\
\text { Helena, MT } 59620 \\
\text { Phone: } 406-444-3412 \\
\text { Fax: } 406-444-4169\end{array}$ & SAME \\
\hline
\end{tabular}




\begin{tabular}{|c|c|c|}
\hline GOVERNOIR & GOV'S REPRESENTATIVE & COORDINATOR \\
\hline $\begin{array}{l}\text { Nebraska } \\
\text { Gov.E. Benjamin E. Nelson (D) } \\
\text { State Capitol Bldg., Lincoln } 68509\end{array}$ & $\begin{array}{l}\text { Jack C. Conrad, Director } \\
\text { Department of Motor Vehicles } \\
\text { *P.O. Box } 94612 \\
\text { 301 Centennial Mall South } \\
\text { Lincoln, NE } 68509 \\
\text { Phone: } 402-471-3900\end{array}$ & $\begin{array}{l}\text { Fred E. Zwonechek, Administralor } \\
\text { Office of Highway Safety } \\
\text { *P.O. Box } 94612 \\
\text { Lincoln, NE } 68509 \\
\text { Phone: } 402-471-2515 \\
\text { Fax: } 402-471-9594\end{array}$ \\
\hline $\begin{array}{l}\text { Nevada } \\
\text { Gov. Robert J. Miller (D) } \\
\text { State Capitol, Carson City } 89710 \\
\text { Phone: 702-885-5670 }\end{array}$ & $\begin{array}{l}\text { James P. Weller, Director } \\
\text { Department of Molor Vehicles } \\
\text { and Public Safety } \\
555 \text { Wright Way } \\
\text { Carson City, NV } 89711-0090 \\
\text { Phone: 702-687-5375 } \\
\text { Fax: 702-687-6798 }\end{array}$ & $\begin{array}{l}\text { Marlen Schultz } \\
\text { Highway Safety Coordinator } \\
\text { Office of Traffic Safety } \\
\text { Dept.of Molor Veh. \& Pub. Saf. } \\
555 \text { Wright Way } \\
\text { Carson Cily, NV } 89711-0090 \\
\text { Phone: 702-687-5720 } \\
\text { Fax:702-687-5328 }\end{array}$ \\
\hline $\begin{array}{l}\text { New IIampshire } \\
\text { Gov. Steve Merrill (R) } \\
\text { State House, Concord } 03301 \\
\text { Phone: } 603-271-2121\end{array}$ & $\begin{array}{l}\text { Joln B. McDuffee, Coordinator } \\
\text { Highway Safety Agency } \\
\text { Pine Inn Plaza } \\
117 \text { Manchester Street } \\
\text { Concord, NH 03301 } \\
\text { Phone: 603-271-2131 } \\
\text { Fax: 603-271-3790 }\end{array}$ & SAME \\
\hline $\begin{array}{l}\text { New Jersey } \\
\text { Gov. James J. Florio (D) } \\
\text { Stale House, Trenton } 08625 \\
\text { Phone: 609-292-6000 }\end{array}$ & $\begin{array}{l}\text { James Arena, Director } \\
\text { Division of Highway Traffic Safety } \\
\text { Dept. of Law \& Public Saf.,CN-048 } \\
\text { Trenton, NJ 08625 } \\
\text { Phone: } 609-588-3750 \\
\text { Fax: } 609-588-7716\end{array}$ & SAME \\
\hline
\end{tabular}




\begin{tabular}{|c|c|c|}
\hline GOVEIRNOR & GOV'S REPRESENTATIVE & COORDINATOR \\
\hline $\begin{array}{l}\text { New Mexico } \\
\text { Gov. Bruce King (D) } \\
\text { Stale Capitol, Santa Fe } 87503 \\
\text { Phone: } 505-827-3000\end{array}$ & $\begin{array}{l}\text { Louis J. Medrano, Secretary } \\
\text { Highway \& Transportation Dept. } \\
1120 \text { Cerrillos Road } \\
\text { P.O. Box } 1149 \\
\text { Santa Fe, NM } 87504-1149 \\
\text { Phone: 505-827-5109 } \\
\text { Fax: 505-827-0431 }\end{array}$ & $\begin{array}{l}\text { John D. Fenner, Chief } \\
\text { Hwy. \& Transportation Dept. } \\
\text { Trafffic Safety Bureau } \\
\text { Montoya Building, Room } 3102 \\
\text { P.O. Box 1149 } \\
\text { Santa Fe, NM 87504-1149 } \\
\text { Phone: 505-827-0427 } \\
\text { Fax: 505-827-0431 }\end{array}$ \\
\hline $\begin{array}{l}\text { New York } \\
\text { Gov. Mario M. Cuomo (D) } \\
\text { State Capitol, Albany } 12224 \\
\text { Phone: } 518-474-8390\end{array}$ & $\begin{array}{l}\text { Patricia B. Adduci } \\
\text { Commissioner of Motor Vehicles } \\
\text { Swan St. Bldg., Empire State Plaza } \\
\text { Albany, NY } 12228 \\
\text { Phone: } 518-474-0841 \\
\text { Fax: } 518-474-9578 \\
\end{array}$ & $\begin{array}{l}\text { William G. Rourke, Exec. Dir. } \\
\text { Governor's Traffic Safety Cmte. } \\
\text { Swan St. Bldg., Empire Plaza } \\
\text { Albany, NY } 12228 \\
\text { Phone: } 518-474-3135 \\
\text { Fax: } 518-473-0041 \\
\end{array}$ \\
\hline $\begin{array}{l}\text { North Coroliua } \\
\text { Gov. Jim Hunt, Jr. (D) } \\
\text { State Capitol, Raleigh } 27603 \\
\text { Phone: 919-733-5811 }\end{array}$ & $\begin{array}{l}\text { Paul B. Jones, Director } \\
\text { Governor's Higliway Safety Program } \\
215 \text { East Lane Street } \\
\text { Raleigh, NC 27601 } \\
\text { Phone: 919-733-3083 } \\
\text { Fax: } 919-733-0604 \\
\end{array}$ & SAME \\
\hline $\begin{array}{l}\text { North Dakota } \\
\text { Gov. Edward Schafer (R) } \\
\text { State Capitol, Bismarck } 58505 \\
\text { Phone: } 701-224-2200\end{array}$ & $\begin{array}{l}\text { Director } \\
\text { Department of Transportation } \\
608 \text { East Boulevard Avenue } \\
\text { Bismarck, ND 58505-0700 } \\
\text { Phone: 701-224-2581 } \\
\text { Fax: 701-224-0426 }\end{array}$ & $\begin{array}{l}\text { Mylo J. Mehlhoff, Director } \\
\text { Drivers Lic. \& Traf. Safety Div. } \\
\text { Department of Transportation } \\
608 \text { East Boulevard Avenue } \\
\text { Bismarck, ND 58505-0700 } \\
\text { Phone: 701-224-2600 } \\
\text { Fax: 701-224-4545 }\end{array}$ \\
\hline
\end{tabular}




\begin{tabular}{|c|c|c|}
\hline GOVERNOR & GOV'S REPRESENTA'TIVE & COORDINATOR \\
\hline $\begin{array}{l}\text { Ohio } \\
\text { Gov. George V. Voinovich (R) } \\
\text { State House, Columbus } 43266-0601 \\
\text { Phone: } 614-466-3555\end{array}$ & $\begin{array}{l}\text { Charles Shipley, Director } \\
\text { OH Dept. of Highway Safety } \\
\text { *P.O. Box } 7167 \\
240 \text { Parsons Avenue } \\
\text { Columbus, OH } 43266-0563 \\
\text { Phone: 614-466-3383 } \\
\text { Fax: 614-466-0433 }\end{array}$ & $\begin{array}{l}\text { Laura Ludwig, Deputy Dir. } \\
\text { Dept. of Highway Safely } \\
\text { *P.O. Box } 7167 \\
240 \text { Parsons Avenue } \\
\text { Columbus, OH } 43266-0563 \\
\text { Phone: 614-466-3250 } \\
\text { Fax: 614-466-0433 }\end{array}$ \\
\hline $\begin{array}{l}\text { Oklahoma } \\
\text { Gov. David Walters (D) } \\
\text { State Capitol, OkJahoma City } 73105 \\
\text { Phone: } 405 / 521-2342\end{array}$ & $\begin{array}{l}\text { Dr. Tim Mauldin, Gov's Rep. } \\
\text { Oklahoma Dept. of Transportation } \\
3223 \text { North Lincoln } \\
\text { Okdahoma City, OK } 73105-5403 \\
\text { Phone: } 405-521-3314 \\
\text { Fax: 405-521-2524 } \\
\end{array}$ & SAME \\
\hline $\begin{array}{l}\text { Oregon } \\
\text { Gov. Barbara Roberts (D) } \\
\text { State Capilol, Salem } 97310 \\
\text { Phone: } 503-378-3111\end{array}$ & $\begin{array}{l}\text { Donald E. Forbes, Director } \\
\text { Department of Transportation } \\
\text { 135 Transportation Building } \\
\text { Salem, OR } 97310 \\
\text { Phone: } 503-378-6388 \\
\text { Fax: } 503-378-8445 \\
\end{array}$ & $\begin{array}{l}\text { Edward Marges, Interim Manager } \\
\text { Traffic Safety Unit } \\
\text { State Library Building } \\
\text { Fourth Floor } \\
\text { Salem, Oregon } 97310 \\
\text { Phone: } 503-378-3669 \\
\end{array}$ \\
\hline $\begin{array}{l}\text { Pennsylvania } \\
\text { Gov: Robert P. Casey (D) } \\
225 \text { Main Capitol Bldg., } \\
\text { Phone: Harrisburg } 17120 \\
\text { 717-787-2500 }\end{array}$ & $\begin{array}{l}\text { Mario D. Pirritano, Deputy Sec. } \\
\text { for Safety Administration } \\
\text { Department of Transportalion } \\
\text { Harrisburg, PA } 17120 \\
\text { Phone: 717-787-3928 } \\
\text { Fax: } 717-787-5491\end{array}$ & $\begin{array}{l}\text { Thomas E. Bryer, P.E. } \\
\text { Director, Center for Hwy. Safely } \\
\text { Department of Transportation } \\
\text { 215 Transportation \& Safety Bldg. } \\
\text { Harrisburg, PA } 17120 \\
\text { Phone: 717-787-7350 } \\
\text { Fax: } 717-783-8217\end{array}$ \\
\hline
\end{tabular}




\begin{tabular}{|c|c|c|}
\hline GOVERNOR & GOV'S REPRESENTATIVE & COORDINATOR \\
\hline $\begin{array}{l}\text { Rhode Island } \\
\text { Gov. Bruce Sundlun (D) } \\
\text { Slate House, Providence } 02903 \\
\text { Phone: } 401-277-2080\end{array}$ & $\begin{array}{l}\text { Danicl P. Fanning, Director } \\
\text { Department of Transportation } \\
\text { State Office Building---Smith Street } \\
\text { Providence, RI 02903 } \\
\text { Phone: } 401-277-2481\end{array}$ & $\begin{array}{l}\text { Edward J. Walsh, Chief Coord. } \\
\text { Governor's Office of Hwy. Safety } \\
345 \text { Harris Avenue } \\
\text { Providence, RI } 02909 \\
\text { Phone: } 401-277-3024 \\
\text { Fax: } 401-277-3942\end{array}$ \\
\hline $\begin{array}{l}\text { South Carolina } \\
\text { Gov. Carroll A. Campbell, Jr. (R) } \\
\text { P.O. Box 11369, Columbia 29211 } \\
\text { Phone: } 803-734-9818\end{array}$ & $\begin{array}{l}\text { Perry Brown, Deputy Director } \\
\text { Office of Highway Safety Programs } \\
\text { Division of Public Safety } \\
1205 \text { Pendleton Street, Rm. } 453 \\
\text { Columbia, SC 29201 } \\
\text { Phone: 803-734-0421 } \\
\text { Fax: 803-734-0486 }\end{array}$ & SAME \\
\hline $\begin{array}{l}\text { South Dakota } \\
\text { Gov. George S. Mickelson (R) } \\
\text { State Capitol, Pierre 57501 } \\
\text { Phone: } 605-773-3212\end{array}$ & $\begin{array}{l}\text { Jeff Stingley, Secretary } \\
\text { Dept. of Commerce \& Regulation } \\
910 \text { E. Sioux } \\
\text { State Capitol Building } \\
\text { Pierre, SD 57501 } \\
\text { Phone: } 605-773-3178 \\
\text { Fax: } 605-773-5369 \\
\end{array}$ & $\begin{array}{l}\text { Jeff Holden, Director } \\
\text { Office Highway Safely } \\
\text { Dept. of Commerce \& Regulation } \\
118 \text { West Capitol Avenue } \\
\text { Pierre, SD 57501 } \\
\text { Phone: 605-773-3675 } \\
\text { Fax: } 605-773-5825 \\
\end{array}$ \\
\hline $\begin{array}{l}\text { Tennessee } \\
\text { Gov. Ned McWherler (D) } \\
\text { State Capitol, Nashville } 37219 \\
\text { Phone: } 615-741-2001\end{array}$ & $\begin{array}{l}\text { Jimmy M. Evans, Commissioner } \\
\text { Department of Transportation } \\
\text { James K. Polk State Office Bldg. } \\
505 \text { Deaderick Streel, Suile } 700 \\
\text { Nashville, TN } 37243-0341 \\
\text { Phone: 615-741-2848 }\end{array}$ & $\begin{array}{l}\text { Clarence Elkins, Director. } \\
\text { Governor's Hwy. Saf. Programs } \\
505 \text { Deaderick Street, Suite } 600 \\
\text { James K. Polk State Office Bldg. } \\
\text { Nashville, TN } 37219 \\
\text { Phone: } 615-741-2589 \\
\text { Fax: } 615-741-2508\end{array}$ \\
\hline
\end{tabular}




\begin{tabular}{|c|c|c|}
\hline GOVERNOR & GOV'S REP'RESENTA'TIVE & COORDINATOR \\
\hline $\begin{array}{l}\text { Texas } \\
\text { Gov. Ann Richards (D) } \\
\text { P.O. Box 12428, Austin } 78711 \\
\text { Phone: } 512-463-8616\end{array}$ & $\begin{array}{l}\text { Arnold Oliver } \\
\text { Gov's Hwy. Safety Representative } \\
\text { TX·Department of Transportation } \\
\text { 125 E. Ilth Street } \\
\text { Austin, TX } 78701-2483 \\
\text { Phone: } 512-463-8616 \\
\text { Fax: } 512-475-3072 \\
\end{array}$ & $\begin{array}{l}\text { Gary K. Trietsch } \\
\text { Traffic Safoly Section (D-18STO) } \\
\text { TX Dept. of Transportation } \\
\text { 125 E. 11th Street } \\
\text { Austin, TX } 78701-2483 \\
\text { Phone: } 512-416-3202 \\
\text { Pax: } 512-416-3161 \\
\end{array}$ \\
\hline $\begin{array}{l}\text { Utah } \\
\text { Gov. Mike Leavilt (R) } \\
\text { State Capitol, Salt Lake City } 84114 \\
\text { Phone: } 801-538-1000\end{array}$ & $\begin{array}{l}\text { D. Douglas Bodrero, Commissioner } \\
\text { Department of Public Safety } \\
\text { 4501 South } 2700 \text { West } \\
\text { Salt Lake City, UT } 84119 \\
\text { Phone: } 801-965-4611 \\
\text { Fax: } 801-965-4756\end{array}$ & $\begin{array}{l}\text { Richard K. Howard, Director } \\
\text { Highway Safety Office } \\
\text { Department of Public Safety } \\
4501 \text { South } 2700 \text { West } \\
\text { Salt Lake City, UT } 84119 \\
\text { Phone: } 801-965-4409 \\
\text { Fax: } 801-965-4969\end{array}$ \\
\hline $\begin{array}{l}\text { Vermont } \\
\text { Gov. Howard Dean }(D) \\
\text { Pavillion Office Building, } \\
\text { Montpelier 05602 } \\
\text { Phone: 802-828-3333 }\end{array}$ & $\begin{array}{l}\text { Michael D. Griffes, Commissioner } \\
\text { Department of Motor Vehicles } \\
120 \text { State Strect } \\
\text { Montpelier, VT 05603-001 } \\
\text { Phonc: } 802-828-2011 \\
\text { Fax: } 802-828-2170\end{array}$ & $\begin{array}{l}\text { Jeanne Johnson, Coordinator } \\
\text { Highway Safety Program } \\
\text { 133 State Street } \\
\text { Montpelier, VT 05603-001 } \\
\text { Phone: 802/828-2665 } \\
\text { Fax: } 802 / 828-2098\end{array}$ \\
\hline $\begin{array}{l}\text { Virginia } \\
\text { Gov. L. Douglas Wilder (D) } \\
\text { State Capitol, Richmond } 23219 \\
\text { Phone: } 804-786-2211\end{array}$ & $\begin{array}{l}\text { Donald E. Williams, Commissioner } \\
\text { Department of Motor Vehicles } \\
\text { *P.O. Box 27412 } \\
\text { 2300 West Broad Street } \\
\text { Richmond, VA } 23269 \\
\text { Phone: } 804-367-6602 \\
\text { Fax: } 804-367-6631\end{array}$ & $\begin{array}{l}\text { William H. Leighty } \\
\text { Dep. Commissioner Trans. Safely } \\
\text { Department of Motor Vehicles } \\
\text { *P.O. Box } 27412 \\
\text { 2300 West Broad Strcet } \\
\text { Richard, VA 23269 } \\
\text { Phone: } 804-367-6614 \\
\text { Fax: 804-367-6631 }\end{array}$ \\
\hline
\end{tabular}




\begin{tabular}{|c|c|c|}
\hline GOVERNOR & GOV'S REPRESENTATIVE & COORDINATOR \\
\hline $\begin{array}{l}\text { Washington } \\
\text { Gov. Mike Lowry (D) } \\
\text { Legislative Building, } \\
\text { Olympia } 98504 \\
\text { Phone: } 206-753-6780\end{array}$ & $\begin{array}{l}\text { Chuck Hayes, Director } \\
\text { Wash. Traffic Safety Commission } \\
\text { l00 Soulh Cherry Street, MS/PD-11 } \\
\text { Olympia, WA } 98504 \\
\text { Phone: 206-735-6197 } \\
\text { Fax: 206-586-6489 }\end{array}$ & $\begin{array}{l}\text { Norm Ericksen, Deputy Director } \\
\text { Washington Traffic Safety Comm. } \\
\text { I000 South Cherry St., MS/PD-11 } \\
\text { Olympia, WA } 98504 \\
\text { Phone: 206-753-6197 } \\
\text { Fax: 206-586-6489 }\end{array}$ \\
\hline $\begin{array}{l}\text { West Virginia } \\
\text { Gov. Gaston Caperton III (D) } \\
\text { State Capitol, Charleston 25305 } \\
\text { Phone:304-348-2000 }\end{array}$ & $\begin{array}{l}\text { James M. Albert } \\
\text { Governor's Rep.for Highway Safety } \\
\text { West Virginia Development Office } \\
1204 \text { Kanawha Boulevard, East } \\
\text { Charleston, WV } 25301 \\
\text { Phone: 304-558-8814 } \\
\text { Fax: } 304-558-0391 \\
\end{array}$ & $\begin{array}{l}\text { James R. Grate } \\
\text { Highway Safely Coordinator } \\
\text { WV Development Office } \\
\text { 1204 Kanawha Boulevard, East } \\
\text { Charleston, WV 25301 } \\
\text { Phone: 304-558-8814 } \\
\text { Fax: 304-558-0391 } \\
\end{array}$ \\
\hline $\begin{array}{l}\text { Wisconsin } \\
\text { Gov. Tommy G. Thompson (R) } \\
\text { State Capitol, Madison } 53702 \\
\text { Phone: } 608-266-1212\end{array}$ & $\begin{array}{l}\text { Charles Thompson, Secretary } \\
\text { WI Dept. of Transportation } \\
\text { Hill Farms State Ofc. Bldg., \#120B } \\
4802 \text { Sheboygan Avenue } \\
\text { P.O. Box } 7910 \\
\text { Madison, WI } 53707-7910 \\
\text { Phone: 608-266-1113 } \\
\text { Fax: 608-266-9912 } \\
\end{array}$ & $\begin{array}{l}\text { David Manning, Director } \\
\text { Office of Transportation Safely } \\
\text { Hill Farms State Ofc. Bldg., } \$ 809 \\
\text { 4208 Sheboygan Avenue } \\
\text { P.O. Box } 7910 \\
\text { Madison, WI 53707-7910 } \\
\text { Phone: } 608 / 267-3710 \\
\text { Fax: } 608 / 267-0441 \\
\end{array}$ \\
\hline $\begin{array}{l}\text { Wyoming } \\
\text { Gov. Mike Sullivan (D) } \\
\text { State Capitol, Cheyenne } 82002 \\
\text { Phone: } 307 / 777-7434\end{array}$ & $\begin{array}{l}\text { Donald G. Pruter } \\
\text { State Hwy. Safety Engineer } \\
\text { Highway Safety Program, DOT } \\
\text { P.O. Box } 1708 \\
\text { Cheyenne, WY } 82002-9019 \\
\text { Phone: (307) 777-4450 } \\
\text { Fax: (307) 777-4250 }\end{array}$ & SAME \\
\hline
\end{tabular}




\begin{tabular}{|c|c|c|}
\hline GOVERNOR & GOV'S REPRESENTATIVE & COORDINATOR \\
\hline $\begin{array}{l}\text { American Samoa } \\
\text { Gov. A. P. Latali } \\
\text { Government House, } \\
\text { Pago Pago 96799 } \\
\text { Phone: 011-684-633-4116 }\end{array}$ & $\begin{array}{l}\text { Tuilefano Vaela'a } \\
\text { Commissioner of Public Safely } \\
\text { Governor's Representative } \\
\text { American Samoa Government } \\
\text { P.O. Box } 1086 \\
\text { Pago Pago, AS } 96799 \\
\text { Phone: 01!-684-633-11!! } \\
\text { Fax: 011-684-633-2979 }\end{array}$ & $\begin{array}{l}\text { Po'oai Ripley } \\
\text { Highway Safety Coordinator } \\
\text { Office of Highway Safely } \\
\text { Government of American Samoa } \\
\text { Pago Pago, AS } 96799 \\
\text { Phone: 011-684-699-9199 }\end{array}$ \\
\hline $\begin{array}{l}\text { Guam } \\
\text { Gov. Joseph Ada (R) } \\
\text { Executive Chambers, Agana } 96910 \\
\text { Phone: 011-671-472-8931 }\end{array}$ & $\begin{array}{l}\text { Benigno Palomo, Director } \\
\text { Department of Public Works } \\
\text { Governor's Hwy Safety Rep. } \\
\text { P.O. Box } 2950 \\
\text { Agana, GU } 96921 \\
\text { Phone: 011-0671-646-3101 } \\
\text { Operator Assisted Calls: } \\
\text { 01-671-646-3101 } \\
\text { Fax: 671-649-6178 }\end{array}$ & $\begin{array}{l}\text { Teresita B. Santos } \\
\text { Highway Safety Coordinator } \\
\text { Department of Public Works, OHS } \\
\text { P.O. Box } 2950 \\
\text { Agana, GU } 96910 \\
\text { Phone: 011-671-646-3211 } \\
\text { Operator Assisted Calls: } \\
\text { 01-671-646-3211 }\end{array}$ \\
\hline $\begin{array}{l}\text { Commonwealth of The Northern } \\
\text { Marina Islands } \\
\text { Gov. Lorenzo I.DeLeon Guerreo } \\
\text { Capitol Hill, Saipan } 96950\end{array}$ & $\begin{array}{l}\text { Gregorio M. Camacho, Dir. } \\
\text { Department of Public Safety } \\
\text { Commonwealth of No.Mariana Isl. } \\
\text { Saipan, CM } 96950 \\
\text { Phone: } 011-670-234-8536 \\
\text { Fax: } 011-670-8531 \\
\end{array}$ & $\begin{array}{l}\text { Priscilla Muna } \\
\text { Highway Safely Coordinator } \\
\text { Office of Highway Safely } \\
\text { Commonwealth of No.Mariana Isl. } \\
\text { Saipan, CM } 96950 \\
\text { Phone: 011-670-234-6021 }\end{array}$ \\
\hline $\begin{array}{l}\text { Puerto Rico } \\
\text { Gov. Pedro Rossello } \\
\text { La Fortaleza, San Juan } 00901\end{array}$ & $\begin{array}{l}\text { Dr. Hermenegildo Ortiz-Quinones } \\
\text { Governor's Rep. for Highway Safely } \\
\text { Sec. of Transp. \& Public Works } \\
\text { Box } 41269 \text {, Minillas Station } \\
\text { Sanlurce, PR } 00940 \\
\text { Phone: } 809-726-6670\end{array}$ & $\begin{array}{l}\text { Ms. Lenidas Ramirez } \\
\text { Executive Director } \\
\text { Traffic Safely Commission } \\
\text { Box } 41289 \text {, Minillas Station } \\
\text { Santurce, PR } 00940 \\
\text { Phone: } 809-723-3590 \\
\text { Fax: } 809-727-0486\end{array}$ \\
\hline
\end{tabular}




\begin{tabular}{|c|c|c|}
\hline GOVERNOR & GOV'S REPRESENTATIVE & COORDINATOR \\
\hline $\begin{array}{l}\text { Virgin Islands } \\
\text { Gov. Alexander A. Farrelly (D) } \\
\text { Government House, } \\
\text { Charlotte Amailie, } \\
\text { St. Thomas } 00801 \\
\text { Phone: } 809-774-0001\end{array}$ & $\begin{array}{l}\text { Enrique Richards } \\
\text { Governor's Representative } \\
\text { VI Office of Highway Safety } \\
\text { Lagoon Street Complex, Fredriksted } \\
\text { St. Croix, VI } 00840 \\
\text { Phonc: } 809-776-5820 \\
\text { Fax: } 809-772-2626 \\
\end{array}$ & SAME \\
\hline Indian Nations & $\begin{array}{l}\text { Dr. Eddie F. Brown } \\
\text { Assistant Sec., Indian Affairs } \\
\text { U.S. Department of the Interior } \\
\text { Mail Stop } 4140 \\
1849 \text { C Street, NW } \\
\text { Washington, DC } 20240 \\
\text { Phone: 202-208-7163 } \\
\text { Fax: 202-208-6334 }\end{array}$ & $\begin{array}{l}\text { Charles L. Jaynes } \\
\text { Program Administrator } \\
\text { Bureau of Indian Affirs } \\
\text { Indian Hwy. Safety Program } \\
\text { *P.O. Box 2006 } \\
\text { Albuquerque, NM } 87103 \\
\text { Phone: 505-766-2863 } \\
\text { Fax: 505-766-3247 }\end{array}$ \\
\hline
\end{tabular}

*/mailing address 
APPENDIX D

DIRECTORY OF NATIONAL ORGANIZATIONS

American Academy of Pediatrics 141 NW Point Blvd.

P.O. Box 972

Elk Grove Village, IL 60009

Contact: Mary C. Sorrentino

708-981-7933

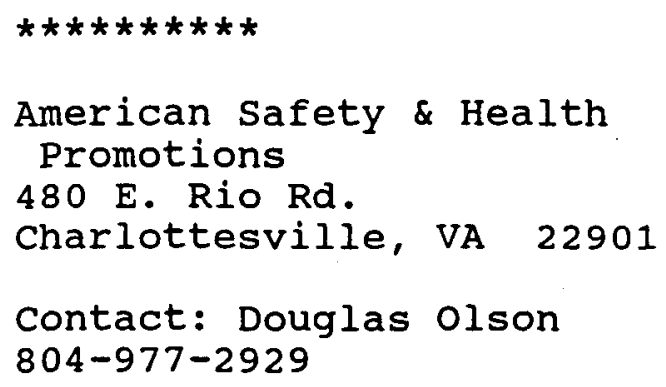

Bell Helmets Inc. 15301 Shoemaker Ave. Norwalk, CA 90650

Contact: Christa Shermer 213-921-9451

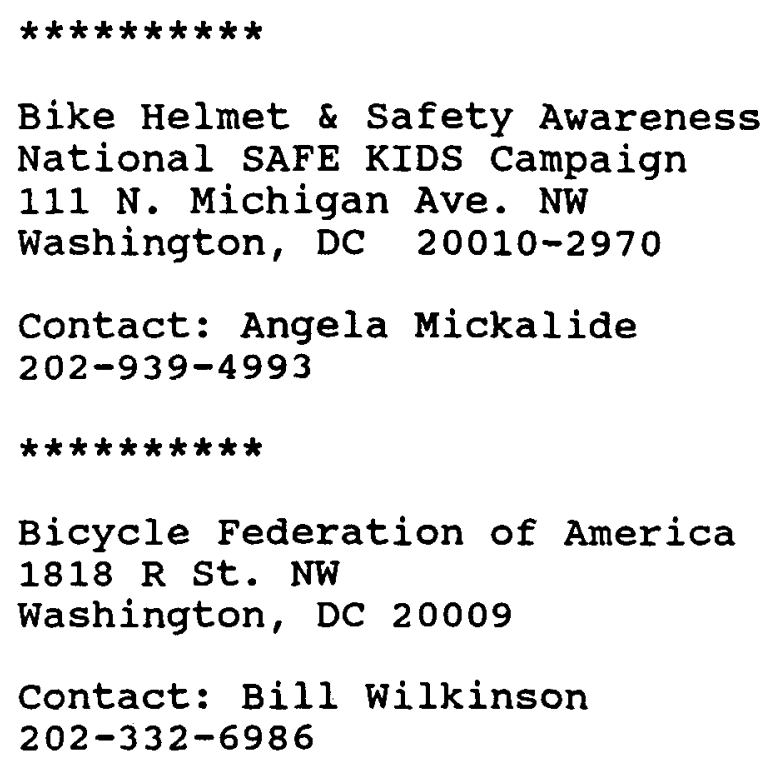

Bike Helmet \& Safety Awareness National SAFE KIDS Campaign $111 \mathrm{~N}$. Michigan Ave. NW

Bicycle Federation of America 1818 R St. NW

Washington, DC 20009

Contact: Bill Wilkinson 202-332-6986

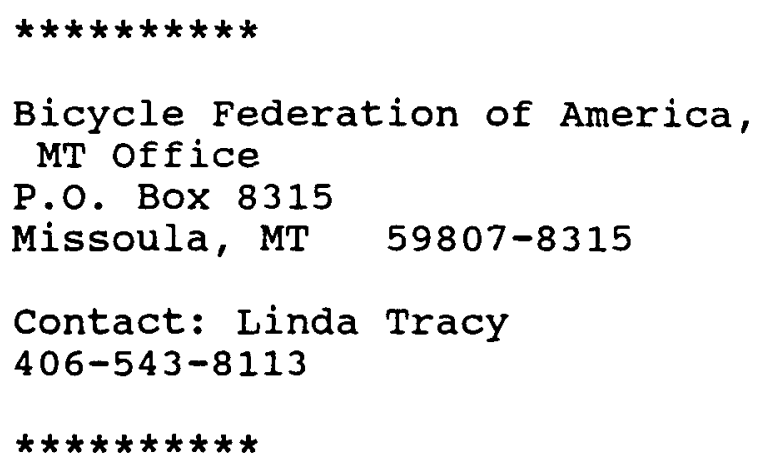

Bicycle Helmet Safety Inst. 4611 Seventh St., South Arlington, VA 22204-1419

Contact: Randy Swart 703-486-0100

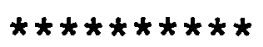

Bicycle Helmets

American Re-Insurance Company 555 College Road East

Princeton, NJ 08542

Contact: Terese Rosenthal

Bicycle Safety Campaign c/o American Academy of Pediatrics/Sandoz

Pharmaceuticals 141 NW Point Blvd Elk Grove Village, IL 60009

Contact: Bill Boyle, M.D. 708-228-5005 
Bikecentennial

P.O. BoX 8308

Missoula, MT 59807

Contact: John Williams

406-721-1776

$\star * \star \star * * * * * *$

Bike Helmet Materials

American Automobile

Association

1000 AAA Drive

Heathrow, FL 32746-5063

Contact: Dean Childs

407-444-7000

$\star * \star * * \star * \star \star *$

Consumer Federation of America 1424 16th street, N.W.

Washington, DC 20036

Contact: Mary Ellen Fise

202-387-6121

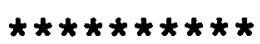

US Consumer Product Safety

Commission

Bicycle Safety

office of Program Management

5401 Westbard. Avenue

Bethesda, MD 20207

Contact: Elaine Tyrrell

301-492-6554

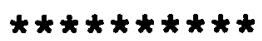

Giros 4 Heroes, Grow with Giro Giro Sport Design 2880 Research Park Dr. Soquel, CA 95073

Contact: Katrin Tobin

800-969-4476
Head Smart

Children's Bicycle Helmet coalition

County Health Department

310 West Poplar

Walla Walla, WA

99362

$\star * * * * * * * * *$

HeadSmart

National Head Injury

Foundation, Suite 812

1140 Connecticut Ave. NW

Washington, DC 20036

Contact: Mary Reitter

202-296-6443

$\star \star \star \star \star \star \star \star \star * * *$

League of American Wheelmen $190 \mathrm{~W}$ Ostend St., Suite 120

Baltimore, MD 21230

Contact: Susie Jones

301-539-3399

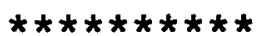

National Association of School Nurses

P.O. Box 1300

Scarborough, ME 04074

Contact: Beverly Farquahar 207-883-2117

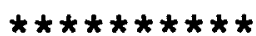

National Highway Traffic Safety Administration

Bicycle Safety, NTS-23 4007 th St., S.W.

Washington, DC 20590

Contact: Leslie Heffner 202-366-2761

$\star \star \star \star \star * * * * * *$ 
National Youth Sports

Foundation for Prevention of Athletic Injuries

10 Meredith Circle

Needham, MA 02192

Contact: Rita Glassman

617-449-2499

$\star * * * * * * * * *$

National PTA

700 N. Rush street

Chicago, IL 60611-2571

Contact: Robert Kociolek

312-787-0977

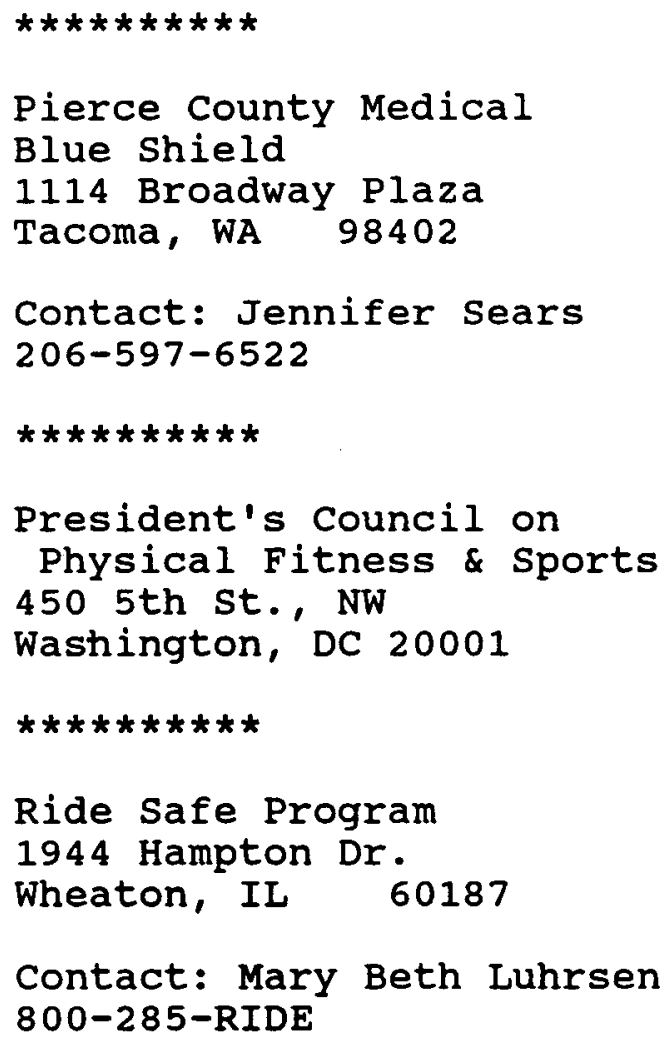

Seattle Bike/Helmet UP

Seattle Bike Supply

1709 E. Del Amo Blvd.

Carson, CA 90746

Contact: Richard Wittenburg 310-604-6036

Sell A Bike, Save A Life Community Traffic Safety Program

Department of Motor Vehicles 3551 Buckner Blvd.

Virginia Beach, VA 23456

Contact: Laura B. Beach 804-363-3929

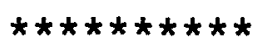

Shinn \& Associates

2853 W. Jolly

Okemos, MI 48864

Contact: David Shinn 517-332-0211

Snell B-90 standard

Snell Memorial Foundation

P.O. Box 493

St. James, NY 11780

Contact: Edward Becker

516-862-6440 


\author{
APPENDIX E
}

\title{
DIRECTORY OF PROMOTIONS
}

\section{INTRODUCTION}

This directory summarizes responses to a survey of bicycle helmet promotions conducted by the Bicycle Federation of America in June 1991. A copy of the survey is presented in Appendix F. No attempt was made to survey every helmet promotion in the United states, but rather to draw contacts from a broad spectrum of fields to create a representative sample.

Surveys were mailed to Bicycle Federation of America contacts, Pro Bike Directory listings, participants of Pro Bike 90 helmet seminar and conference workshop, Governor's Highway Traffic Safety Representatives, and the NHTSA Regional Offices. Surveys also were mailed to contacts identified by the National Safe Kids Campaign (state and local coalitions), the American Academy of Pediatrics (mini-grant recipients), and the Centers for Disease Control (injury control centers, related grant recipients, and selected conference participants). Major bicycle helmet manufacturers, retail distributors, and bulk purchase distributors also provided lists of people and organizations that had contacted them for information.

The list generated from these various sources was culled of its many duplicates to create a mailing list of 735 entries. It should be noted, however, that many organizations were represented by multiple entries, but with different contact people or in some cases, different addresses. Some of the entries for larger organizations or government agencies had as many as eight different contact people. From the 735 listings, approximately 550 separate organizations and non-affiliated individuals received the survey. Twenty-one of the surveys were returned because of bad addresses.

Some form of response was received from 263 individuals, representing 40 states, the District of Columbia, and Guam. of these, 32 reported they had no information to share at the time. Most stated that they intended to conduct some form of helmet promotion in the future, but had not yet begun any activities. of the 231 remaining responses, four were supplemental responses by a second person involved in the same promotion, and five specifically requested not to be included in the directory. The directory that follows thus contains 222 listings. 
Entries are presented in alphabetical order, first by state, then by city within the state. Each entry includes mailing address, contact information, if available, and some summary details about the promotion. Summary information on target audience, strategy, coalition, and evaluation are coded as follows:

Target Audience: Kids: Children 12 and under

Parents: Parents

Teens: 13 to 19 year olds

College students: College students

Adults: Adults

All ages: All ages

NA: Information not available

Strategy: PI\&E: Awareness and knowledge of head injury and use of bicycle helmets through public information and education efforts

Distribution: Helmet distribution efforts, discount coupons, bulk purchasing programs

Use: Activities to promote helmet use

Aid: Provides information and other support for other promotions

NA: Information not available

Coalition: Yes: Used or uses at least one additional organization

No: Lead organization or individual only

NA: Information not available

Evaluation: None: None indicated or no information provided

Limited: Limited evaluation or limited information provided

Comprehensive: Comprehensive evaluation either extensively documented or more than one measure used

NA: Information not available 


\section{ALABAMA}

Safe Kids Bicycle Helmet Promotion

SE Child Safety Institute Children's Hospital of AL 16007 th Ave. South

Birmingham, AL 35233

205-939-9720

Contact: Dr. William D. King

Target: Kids, Parents

Strategy: PI\&E, Distribution Coalition: Yes

Funding: $\$ 1000-\$ 5000 / \mathrm{Yr}$

Project Length: Multi-year

Geographic Area: County

Evaluation: Comprehensive

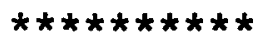

Department of Education

$50 \mathrm{~N}$. Ripley st.

Gordon Person Bldg., Room 3339

Montogmery, AL 36130-3901

205-242-8013

Contact: C. Wayland Blake

Target: Kids

strategy: PI\&E

Coalition: Yes

Funding: NA

Project Length: 1 day

Geographic Area: Local

Evaluation: None

\section{ALASRA}

SAFE KIDS

Providence Hospital

Box 19-6604

Anchorage, AK 99519-6604

Contact: Joan Diamond
Target: Kids

Strategy: PI\&E, Distribution, Use, Aid

Coalition: Yes

Funding: NA

Project Length: 3-12 months

Geographic Area: state, Local

Evaluation: Limited

$\star * * * * * * * * *$

Earth Day 1990, 1991

Alaska Head Injury Association Box 84127

Fairbanks, AK 99708

$907-452-4761$

Contact: Nicole McCullough

Target: All ages

Strategy: Distribution

Coalition: No

Funding: Less than $\$ 500 / y r$.

Project Length: $1-3$ months

Geographic Area: Local

Evaluation: Comprehensive

\section{ARIZONA}

Helmet Your Head

Glendale American School

$8530 \mathrm{~N}$ 55th Ave

Glendale, AZ 85302

Contact: Carolyn Ewing, R.N.

Target: Kids, Parents

Strategy: PI\&E, Distribution

Coalition: Yes

Funding: NA

Project Length: 1 day

Geographic Area: Local

Evaluation: None 
Bike Rodeo - SAFE KIDS

Campaign

Yavapai County Health Dept.

930 Division st

Prescott, AZ 86301

Contact: Luana Marigold

Target: Kids, Parents

Strategy: PI\&E

Coalition: Yes

Funding: NA

Length: 1-3 nonths

Geographic Area: County

Evaluation: limited

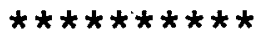

Bicycle Safety Course

AZ state University

Department of Public safety

628 E. Apache

Tempe, AZ 85287

602-965-8035

contact: Sgt. William wright

Target: College students

Strategy: PI\&E, Use

Coalition: No

Funding: NA.

Project Length: Multi-year

Geographic Area: Local

Evaluation: None

\section{CALIFORNIA}

Helmet Prograin

Indian Health, Inc.

11555 1/2 Potjero Rd

Banning, CA 92220

Contact: Luis Tellez

Target: Kids

Strategy: PIXE, Distribution Coalition: No

Funding: $\$ 1000-\$ 5000 / \mathrm{Yr}$.

Project Length: Multi-year

Geographic Area: county

Evaluation: None

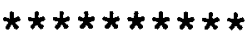 \\ Seattle Bike/Helmet UP \\ Seattle Bike Supply \\ 1709 E. Del Amo Blvd. \\ Carson, CA 90746 \\ $310-604-6036$ \\ Contact: Richard Wittenburg \\ Target: Kids \\ Strategy: PI\&E, Distribution \\ Coalition: Yes \\ Funding: in-kind only \\ Project Length: Multi-year \\ Geographic Area: Nation \\ Evaluation: Limited \\ $\star * \star \star \star * * \star * \star$ \\ Health Education Dept. \\ CareAmerica Health Plan \\ 20520 Norhoff \\ Chatsworth, CA 91311 \\ Contact: Erika Frand \\ Target: All ages \\ Strategy: PI\&E, Distribution \\ Coalition: No \\ Funding: NA \\ Project Length: Multi-year \\ Geographic Area: Region \\ Evaluation: Limited
}

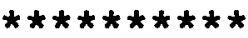

Butte County Heath Dept.

Health Education Dept:

695 Oleander Avenue

Chico, CA 95926

916-891-2768

Contact: Byron Brace

Target: All ages

strategy: PI\&E

Coalition: No

Funding: Part of bike program Project Length: Multi-year

Geographic Area: County

Evaluation: None 


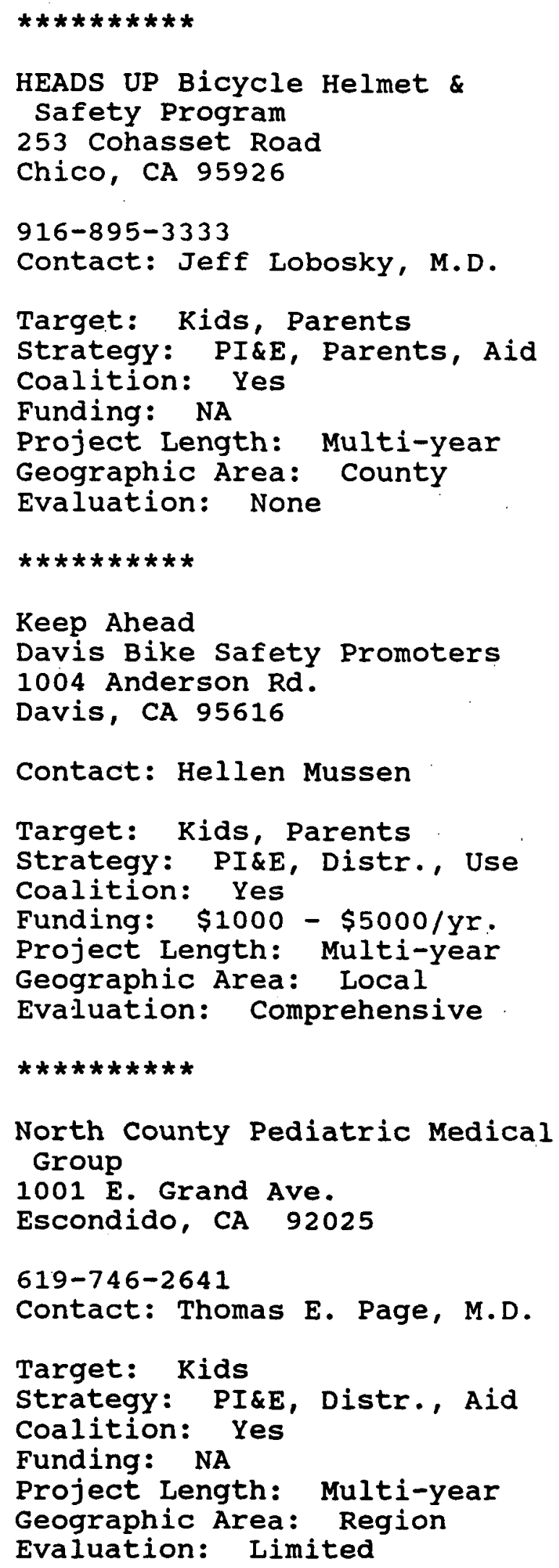

North County Pediatric Medical Group 1001 E. Grand Ave.

Solono county Bicycle Safety Campaign

Head Injury Prevention, Inc. PO Box Z

Fairfield, CA 94533

707-422-1040

Contact: Marjorie King

Target: Kids, Parents Strategy: PI\&E, Distr., Aid Coalition: Yes

Funding: Less than $\$ 500 / y r$. Project Length: Multi-year Geographic Area: County Evaluation: None

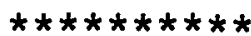

Bicycle Safety Awareness Program

City of Irvine

1 Civic Center Plaza

P.O. Box 19575

Irvine, $C A$

92713

$714-854-8144$

Contact: Bill sellin

Target: Kids

Strategy: PI\&E, Distribution Coalition: Yes

Funding: over $\$ 5000 / \mathrm{yr}$. Project Length: Multi-year Geographic Area: Local

Evaluation: Comprehensive

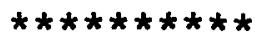

Bicycle Helmet Interest Group City of Irvine

1 Civic Center Plaza

P.O. BoX 19575

Irvine, $\mathrm{CA} \quad 92713$

$714-724-6227$

Contact: Katherine Lyon

(listing continued next page) 
Target: Kids

Strategy: PI\&E, Distribution

Coalition: Yes

Funding: NA

Project Length: Multi-year

Geographic Area: Local

Evaluation: Comprehensive

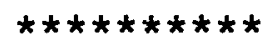

Traffic Safety

Los Angeles Police Department 4125 S. Crenshaw Blvd.

Los Angeles, C:A 90008

213-485-7742

Contact: Forrest wilkins

Target: Kids

Strategy: PI\&E

Coalition: No

Funding: NA

Project Length: Multi-year

Geographic Area: Local

Evaluation: Jimited

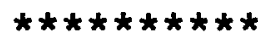

Bell Helmets Inc.

15301 Shoemaker Ave.

Norwalk, CA 90650

213-921-9451

Contact: Christa Shermer

Target: Kids, Parents

Strategy: PI\&E, Distr., Aid

Coalition: Yes

Funding: over $\$ 5000 / \mathrm{yr}$.

Project Length: Multi-year

Geographic Area: Nation

Evaluation: Comprehensive

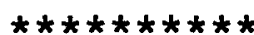

Bike Safety in Elementary

Schools

Maidu Cyclists

1828 Woodacre

Roseville, CA. 95661
Contact: Dave scott

Target: Kids, Parents

strategy: PI\&E

Coalition: Yes

Funding: NA

Project Length: 3-12 months

Geographic Area: Local

Evaluation: Limited

$\star \star \star \star * \star * \star * \star \star$

High Risk Minority \& Youth Project

Injury Prevention Program

Monterey County Health Dept.

955 Blanco Circle, suite D

Salinas, CA 93901

$408-755-4538$

Contact: Diana Jacobson

Target: Kids, all adults

Strategy: PI\&E, Distribution

Coalition: Yes

Funding: NA

Project Length: Multi-year

Geographic Area: County

Evaluation: None

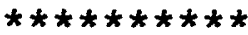

San Diego City Bicycle Program 1010 Second Avenue

M.S. 644

San Diego, CA 92101

$619-533-3029$

Contact: Michael E. Jackson

Target: All ages

Strategy: PI\&E

Coalition: Yes

Funding: Over $\$ 5000 / y r$.

Project Length: Multi-year

Geographic Area: Local

Evaluation: Limited 
Center for Childhood Injury Prevention

San Diego State University 6505 Alvarado Rd., Suite 205

San Diego, CA 92120

619-594-3691

Contact: Sylvia Micik, M.D.

Target: Kids

Strategy: PI\&E

Coalition: Yes

Funding: $\$ 1000-\$ 5000 / \mathrm{yr}$.

Project Length: Multi-year

Geographic Area: Region

Evaluation: Comprehensive

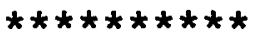

Bicycle Planning \& Safety County RegionalTrans. Comm.

701 Ocean St., Rm. 406-B

Santa Cruz, CA 95060-4071

$408-425-2951$

Contact: Jack Witthaus

Target: All ages

Strategy: PI\&E, Distribution Coalition: Yes

Funding: Part of bike program Project Length: Multi-year Geographic Area: Region, Co. Evaluation: None
\end{abstract}

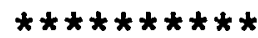

Giros 4 Heroes, Grow with Giro Giro Sport Design 2880 Research Park Dr. Soquel, CA 95073

$800-969-4476$

Contact: Katrin Tobin

Target: Kids, Parents

Strategy: PI\&E, Distr., Aid Coalition: Yes

Funding: NA

Project Length: Multi-year Geographic Area: Nation

Evaluation: None

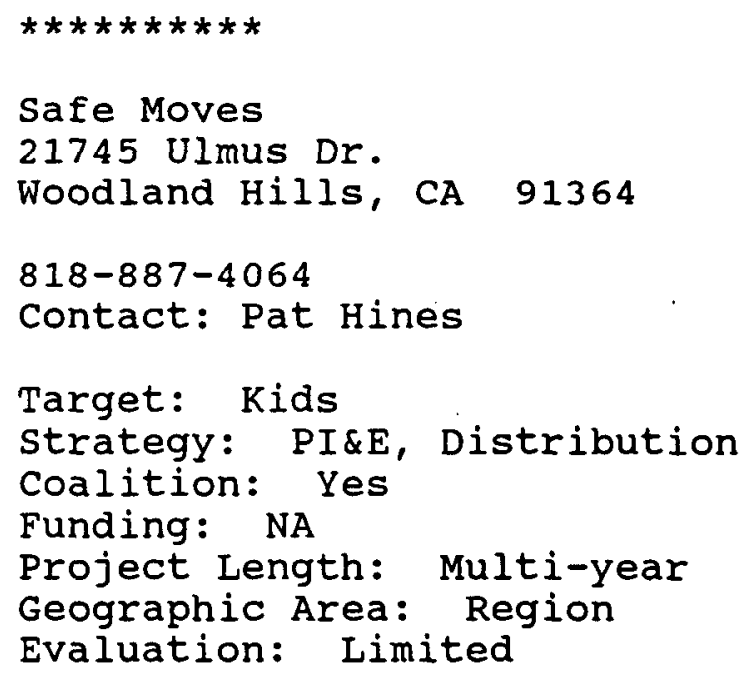

Target: Kids

strategy: PI\&E, Distribution Coalition: Yes

Funding: NA

Project Length: Multi-year Geographic Area: Region

Evaluation: Limited

\section{COLORADO}

Bike Safety Poster contest, Helmet Survey

SAFE KIDS Coalition

Department of Health

4210 East 11th Avenue

Denver, CO 80220

303-331-8367

Contact: Dominique Fauble, MPA

Target: Kids

Strategy: PI\&E, Distribution Coalition: Yes

Funding: $\$ 1000-\$ 5000 / \mathrm{yr}$.

Project Length: Multi-year

Geographic Area: State

Evaluation: None

$\star \star \star \star * \star \star \star * \star *$

Golden Bicycle Helmet Project Self Propulsion, Inc.

1212 Washington

Golden, $C O \quad 80401$

$303-278-3290$

Contact: Portia Masterson

(listing continued next page) 
Target: Kids;, Parents

Strategy: PI\&E, Distr., Use Coalition: Yes

Funding: NA

Project Length: 1-3 mo's/yr

Geographic Area: Local

Evaluation: None

\section{CONNECTICUT}

Bike Safety Rodeo

Greenwich Safe Kids coalition 189 Mason st.

Greenwich, CT 06830

203-869-0200

Contact: Peter J. Fliehl

Target: Kids

Strategy: PI\&E, Distribution Coalition: Yes

Funding: NA

Project Length: Multi-year

Geographic Area: Local

Evaluation: Limited

Bicycle Helmet Campaign

Childhood Injury Prevention

Center

80 Seymour St.

Hartford, CT 06115

203-524-3003

Contact: Mary Braddock, M.D.

Target: Kids

Strategy: PI\&E, Distr., Aid Coalition: Yes

Funding: $\$ 1000-\$ 5000 / y r$. Project Length: Multi-year Geographic Area: State Evaluation: Comprehensive

$\star \star \star \star * * * * * * \star$

GEAR ' 90

Coalition of CT Bicyclists

P.O. Box 121

Middletown, CT 06457
Contact: Linda E. Bireley

Target: All ages

Strategy: PI\&E, Use

Coalition: Yes

Funding: Part of bike program

Project Length: $1-3$ months

Geographic Area: Region

Evaluation: None

$\star * * * * * * * * *$

Reducing Child Injury Thru

Bike Helmets

Dunlap \& Associates, Inc.

17 Washington street

Norwalk, CT 06854

203-866-8464

Contact: Richard D. Blomberg

Target: Kids

Strategy: PI\&E, Distribution, Use, Aid

Coalition: Yes

Funding: Over $\$ 5000 / y r$.

Project Length: Multi-year

Geographic Area: Local

Evaluation: Comprehensive

\section{DELAFARE}

1991 Helmet Promo Week/Month

Delmarva Wheelmen

Wheel Easy Bicycle store

1404 Forrest Ave.

Dover, DE 19901

$302-734-4994$

Contact: Howard D. Smith

Target: All ages

Strategy: PI\&E, Distribution

Coalition: Yes

Funding: in-kind \& volunteers

Project Length: 1-3 months

Geographic Area: Local

Evaluation: Limited 
Bicycle Safety Ed. Program Univ. of DE - Coop. Extension R.D. 2, Box 48 Georgetown, DE 19947

302-856-7303

Contact: Ron Jester

Target: Kids, Parents

Strategy: PI\&E

Coalition: Yes

Funding: $\$ 1000-\$ 5000 / \mathrm{yr}$.

Project Length: $1-3$ months

Geographic Area: Region, st. Evaluation: Limited

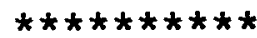

Helmet Use Promotion White Clay Bike Club 49 Marsh Woods Lane Wilmington, DE 19810

Contact: Don Carbaugh

Target: Kids

Strategy: PI\&E, Distribution Coalition: Yes

Funding: $\$ 1000-\$ 5000 / \mathrm{Yr}$. Project Length: Multi-year Geographic Area: County Evaluation: Comprehensive

\section{DISTRICT OF COLUMBIA}

HeadSmart

National Head Injury

Foundation, suite 812

1140 Connecticut Ave. NW Washington, DC 20036

202-296-6443

Contact: Mary Reitter

Target: Kids

Strategy: PI\&E, Aid

Coalition: Yes

Funding: over $\$ 5000 / \mathrm{Yr}$.

Project Length: Multi-year

Geographic Area: Nation

Evaluation: Limited

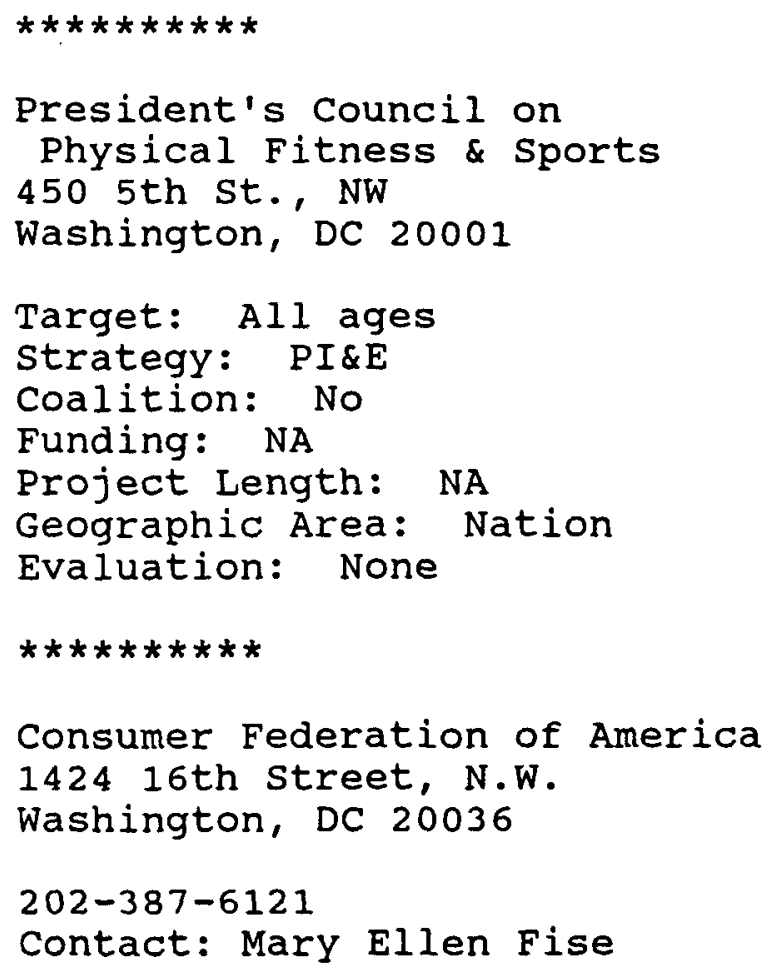

President's Council on Physical Fitness \& Sports 450 th st., NW Washington, DC 20001

Target: All ages

Strategy: PI\&E Coalition: No Funding: NA Project Length: NA Geographic Area: Nation Evaluation: None

$\star \star \star \star \star \star * * \star * *$

Consumer Federation of America 1424 16th Street, N.W. Washington, DC 20036

$202-387-6121$

Contact: Mary Ellen Fise

Target: All ages

Strategy: PI\&E, Aid

Coalition: Yes

Funding: NA

Project Length: Multi-year Geographic Area: Nation

Evaluation: None

Department of Public Works 200014 th st NW, 7th floor Washington, DC 20009

$202-939-8016$

Target: Parents

strategy: PI\&E

Coalition: Yes

Funding: NA

Project Length: Multi-year Geographic Area: Local

Evaluation: Limited 
Bike Helmet \& Safety Awareness National SAFE KIDS Campaign $111 \mathrm{~N}$. Michicjan Ave. NW Washington, IDC 20010-2970

202-939-4993

Contact: Angela Mickalide

Target: Kids, Parents

Strategy: PI\&E, Distribution, Use, Aid

Coalition: Yes

Funding: over $\$ 5000 / y r$.

Project Length: Multi-year

Geographic Area: Nation

Evaluation: Comprehensive

$* * * * * * * * * *$

Bicycle Federation of America 1818 R St. NW

Washington, DC 20009

202-332-6986

Contact: Bill wilkinson

Target: All ages

Strategy: PI\&E, Aid

Coalition: Yes

Funding: Part of bike program Project Length: Multi-year

Geographic Alrea: Nation

Evaluation: Limited

\section{FLORIDA}

Bicycle Advisory Committee County Metro. Planning org. 14 S. Fort Harrison Avenue clearwater, JPL 34616

813-462-4751

Contact: Kay Medwick

Target: Kidis, Adults

Strategy: PI\&E, Distribution Coalition: Yes

Funding: NA

Project Length: Multi-year Geographic Area: Co., Local Evaluation: Limited

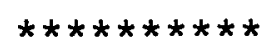

Bike Helmet Materials

American Automobile

Association

1000 AAA Drive

Heathrow, FL 32746-5063

407-444-7000

Contact: Dean Childs

Target: Kids

Strategy: PI\&E

Coalition: No

Funding: NA

Project Length: Multi-year

Geographic Area: Nation

Evaluation: None

$\star * * * * * * * * *$

Miami Children's Hospital

6125 SW 31st St

Miami, FL 33155

305-666-6511, ext 2516

Contact: Brian Hannigan, R.N.

Target: Kids, Parents

Strategy: PI\&E, Distribution

Coalition: Yes

Funding: over $\$ 5000 / \mathrm{yr}$.

Project Length: Multi-year

Geographic Area: County

Evaluation: Limited

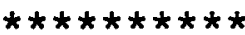

Dade County Public Schools 1450 Northeast Second Ave \#904 Miami, FL 33132

305-995-1986

Contact: Bill Harris

Target: Kids

Strategy: PI\&E, Distribution Coalition: No

Funding: NA

Project Length: NA

Geographic Area: Local

Evaluation: Limited 
Reducing Child Injury Thru

Bike Helmets

W. FL Reg. Planning Council

P.O. Box 486

Pensacola, FL 32593-0486

$904-444-8910$

Contact: Tim Bustos

Target: All ages

Strategy: PI\&E, Distribution, Use, Aid

Coalition: Yes

Funding: NA

Project Length: Multi-year

Geographic Area: Region

Evaluation: Comprehensive

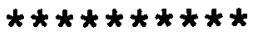

Safe Kids on the Block

Think First - Northwest Fl

8383 N. Davis Hwy

Pensacola, FL 32514

Target: Kids

Strategy: PI\&E, Distribution

Coalition: Yes

Funding: $\$ 1000-\$ 5000 / \mathrm{yr}$.

Project Length: 1-3 months

Geographic Area: Local

Evaluation: None

Helmet Promotion week

orlando Area Bic./Ped. Program

1011 Wymore Rd., Suite 105

Winter Park, FL 32789

407-623-1075

Contact: Thomas Cerny

Target: All ages

Strategy: PI\&E, Distribution Coalition: Yes

Funding: NA

Project Length: 1-3 months

Geographic Area: Region

Evaluation: None

\section{GEORGIA}

SAFE KIDS of Georgia

Egleston Children's Hospital 1405 Clifton Rd. NE

Atlanta, GA 30322-1101

Target: All ages

Strategy: PI\&E

Coalition: No

Funding: NA

Project Length: 3-12 months

Geographic Area: State

Evaluation: None

$\star \star \star \star \star \star \star \star \star * \star *$

Safe Kids of Dekalb

Dekalb County Board of Health

3651 Market st.

clarkston, GA 30021

404-292-1979

Contact: Rema Afifi

Target: Kids, Parents

strategy: NA

Coalition: Yes

Funding: NA

Project Length: NA

Geographic Area: County

Evaluation: None

Study of Bicycle Helmet

Ownership \& Usage Among

Elementary School Children

3666 Heatherwood Dr.

Marietta, GA 30066

Contact: Laura Searcy

Target: Kids, Parents

Strategy: PI\&E, Distr., Aid Coalition: No

Funding: Less than $\$ 500 / y r$. Project Length: 3-12 months Geographic Area: Local

Evaluation: Comprehensive 
Chatham county Public Health

Department

Injury Prevention Program

P.O. Box 14257

Savannah, GA 31416-1257

$912-356-2160$

Contact: Mary Y. Smith

Target: Kids, Parents

Strategy: PI\&E

Coalition: Yes

Funding: NA

Project Length: Multi-year

Geographic Area: County

Evaluation: None

\section{GUAM}

office of Highway Safety

P.O. BoX 2950

Agana, GUAM 96910

Contact: Annie Santos

Target: All ages

strategy: PI\&E

Coalition: Yes

Funding: NA

Project Length: Multi-year

Geographic Area: Local

Evaluation: None

\section{ILLINOIS}

McLean Chapter - American Red Cross

One Westport Court

Bloomington, IL 61704

309-662-0500

Contact: Becky Barnes

Target: All ages

strategy: PI\&E, Distribution Coalition: No

Funding: in-kind \& volunteers

Project Length: 1-3 months

Geographic Area: County

Evaluation: None

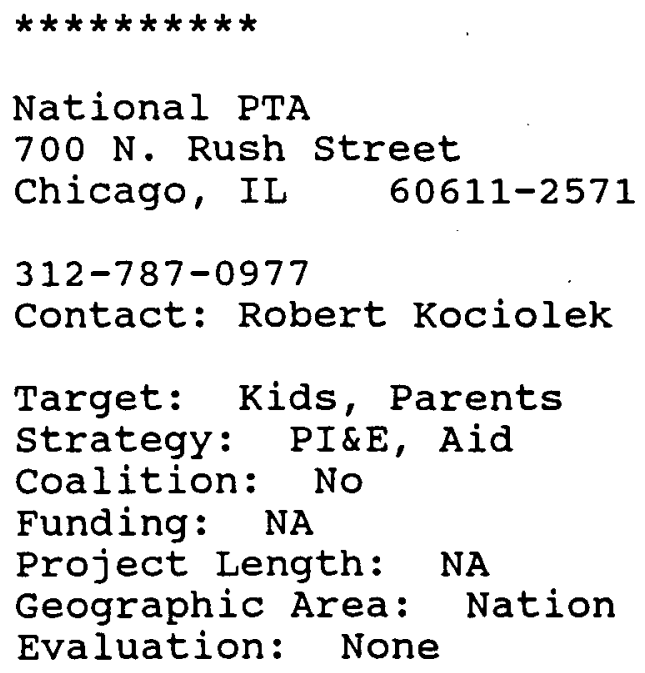

National PTA

$700 \mathrm{~N}$. Rush street

Chicago, IL 60611-2571

312-787-0977

Contact: Robert Kociolek

Target: Kids, Parents

strategy: PI\&E, Aid

Coalition: No

Funding: NA

Project Length: NA

Geographic Area: Nation

Evaluation: None

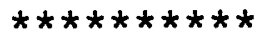

American Academy of Pediatrics 141 NW Point Blvd.

P.O. Box 972

Elk Grove Village, IL 60009

708-981-7933

Contact: Mary C. Sorrentino

Target: All ages

Strategy: PI\&E, Aid

Coalition: Yes

Funding: over $\$ 5000 / \mathrm{yr}$.

Project Length: Multi-year

Geographic Area: Nation

Evaluation: Limited

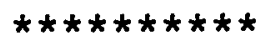

Bicycle Safety Campaign

Minigrants

American Academy of

Pediatrics, c/O AAP/Sandoz

Pharmaceuticals

141 NW Point Blvd

Elk Grove Village, IL 60009

$708-228-5005$

Contact: Bill Boyle, M.D.

(listing continued next page) 
Target: Adults

Strategy: PI\&E, Aid

Coalition: Yes

Funding: Over $\$ 5000 / y r$.

Project Length: Multi-year

Geographic Area: Nation

Evaluation: Comprehensive

\section{$\star \star * \star * * * * * *$ \\ Bike safety clinic \\ Gulfview Hills Women's club \\ Youth Affairs \\ 5701 South Monroe \\ Hinsdale, IL 60521 \\ Contact: Mary Jane stitt}

Target: Kids

Strategy: PI\&E, Distribution

Coalition: No

Funding: Less than $\$ 500 / y r$.

Project Length: $1-3$ months

Geographic Area: Local

Evaluation: Limited

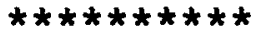 \\ Bike Safety Helmet Promotion \\ Heather Stewart Memorial \\ Foundation \\ 14028 Pawnee Lane \\ Lockport, IL 60441 \\ Contact: Roy stewart \\ Target: All ages \\ Strategy: PI\&E, Distribution \\ Coalition: Yes \\ Funding: NA \\ Project Length: Multi-year \\ Geographic Area: Local \\ Evaluation: Limited}

$\star \star \star \star \star \star * * * * *$

IL League of American Wheelmen 2801 Morcambe Bay Dr.

New Lenox, IL 60451

Contact: William R. Lang
Target: Adults

Strategy: PI\&E

Coalition: Yes

Funding: NA

Project Length: 3-12 months

Geographic Area: Local

Evaluation: None

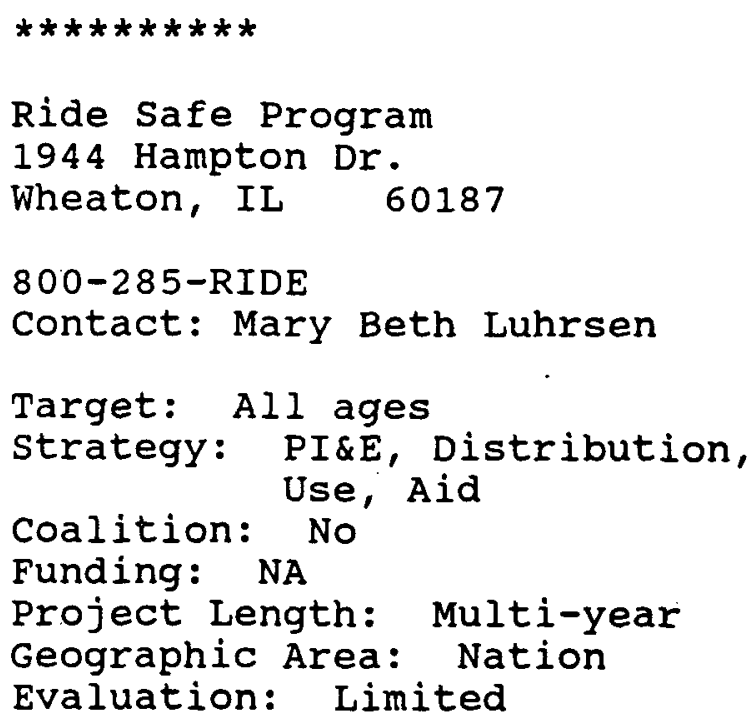

\section{INDIANA}

SAFE KIDS Coalition

Riley Kiwanis Trauma Life

Center, Riley Hospital

702 Barnhill Drive

Indianapolis, IN 46202

Contact: Judy Doll

Target: Kids

Strategy: PI\&E

Coalition: Yes

Funding: $\$ 501-\$ 1000 / y r$.

Project Length: Multi-year

Geographic Area: Local

Evaluation: Limited

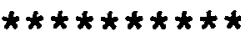

Bicycle Helmet Campaign

IN Chpt. Amer. Acad. of Ped.

Methodist Hospital of Indiana

1701 N. Senate Ave.

Indianapolis, IN 46202 
Contact: Charlene Graves, M.D.

Target: Kids, all adults Strategy: FI\&E, Distr., Aid Coalition: Yes

Funding: $\$ 1.000-\$ 5000 / \mathrm{yr}$. Project Length: Multi-year Geographic Area: Region, st. Evaluation: Limited

\section{IOWA}

st. Luke's Hospital Auxiliary 810 First Avenue NE

Cedar Rapids, IA 52402

Contact: Marilyn Thomsen

Target: All ages

Strategy: PI\&E, Distribution Coalition: No

Funding: NA

Project Length: Multi-year

Geographic Area: Local

Evaluation: Limited

\section{RANSAS}

Backroads Bicycling

P.O. Box 372

Clay Center, KS 67432-0372

Contact: Randy W. Wyatt

Target: All ages

Strategy: PI\&E

Coalition: Yes

Funding: Less than $\$ 500 / y r$.

Project Length: Multi-year

Geographic Area: Local

Evaluation: None

Bicycle Helmet Campaign

SAFE KIDS/Riverside Hospital

$2622 \mathrm{~W}$ : Central

Wichita, KS 67203-4999
316-946-8690

Contact: Debra Logan

Target: Kids, Parents

Strategy: PI\&E, Distribution Coalition: Yes

Funding: over $\$ 5000 / \mathrm{yr}$.

Project Length: Multi-year

Geographic Area: Local

Evaluation: Limited

\section{RENTUCKY}

Bicycle Safety Awareness Week SAFE KIDS Campaign

PO Box 1864

Ashland, KY

606-327-2077

Contact: Lt. Donald O'Pell

Target: Kids

Strategy: PI\&E, Distribution Coalition: Yes

Funding: $\$ 1000-\$ 5000 / \mathrm{yr}$.

Project Length: 3-12 months

Geographic Area: Region

Evaluation: None

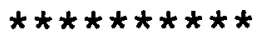

Warren County Medical Society Auxiliary

Bicycle Helmet Safety Program 4879 Smallhouse Rd.

Bowling Green, KY 42104

502-781-1842

Contact: Karen G. Watson

Target: Kids

Strategy: PI\&E, Distribution Coalition: Yes

Funding: $\$ 1000-\$ 5000 / y r$.

Project Length: $1-3$ months

Geographic Area: Local

Evaluation: Limited 


\section{LOUISIANA}

Safety Council, SW Louisiana 1021 Ryan Street

Lake Charles, LA 70601

Target: Kids

Strategy: PI\&E

Coalition: Yes

Funding: Less than $\$ 500 / \mathrm{yr}$.

Project Length: 1-3 months

Geographic Area: Local

Evaluation: None

$\star \star \star \star * \star * \star * * *$

Helmets Are Not to Die For The Bikesmith Inc.

4716 Freret

New Orleans, LA 70115

504-897-2453

Contact: Bill Port

Target: Kids

Strategy: PI\&E, Distribution Coalition: No

Funding: NA

Project Length: Multi-year

Geographic Area: Local

Evaluation: None

$\star \star \star \star * \star * \star * \star *$

National Safe Helmet Campaign Holy Name of Jesus

Parent-Teacher Club

938 Lafayette St., Suite 428

New orleans, LA 70130

Contact: Diane Lyons

Target: Kids

Strategy: PI\&E

Coalition: No

Funding: Less than $\$ 500 / y r$.

Project Length: 3-12 months

Geographic Area: Local

Evaluation: Limited
Governor's Task Force on Bike Safety

P.O. Box 24937

New Orleans, LA 70184

Contact: Bill Keller

(no other information)

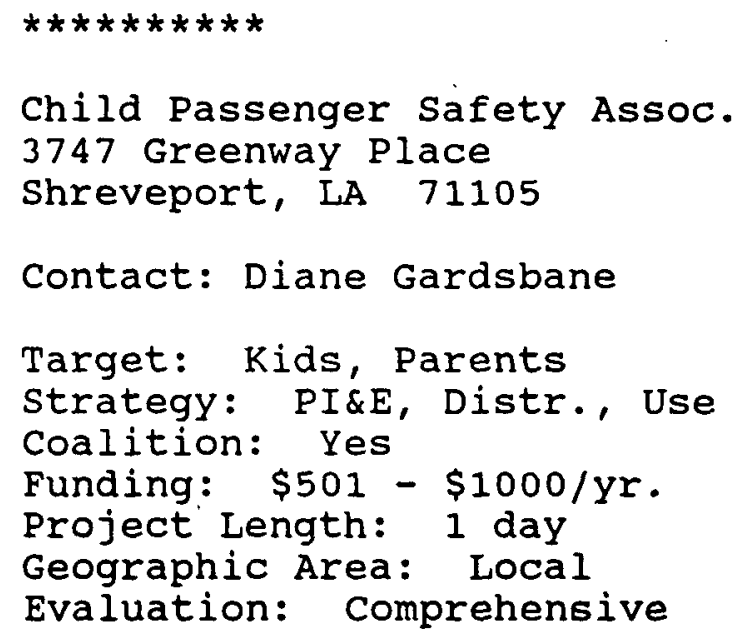

Child Passenger Safety Assoc.

3747 Greenway Place

Shreveport, LA 71105

Contact: Diane Gardsbane

Target: Kids, Parents

Strategy: PI\&E, Distr., Use

Coalition: Yes

Funding: $\$ 501-\$ 1000 / y r$.

Project Length: 1 day

Geographic Area: Local

Evaluation: Comprehensive

\section{MAINE}

National Association of School Nurses

P.O. Box 1300

Scarborough, ME 04074

207-883-2117

Contact: Beverly Farquahar

Target: NA

Strategy: PI\&E

Coalition: Yes

Funding: NA

Project Length: NA

Geographic Area: Nation

Evaluation: None

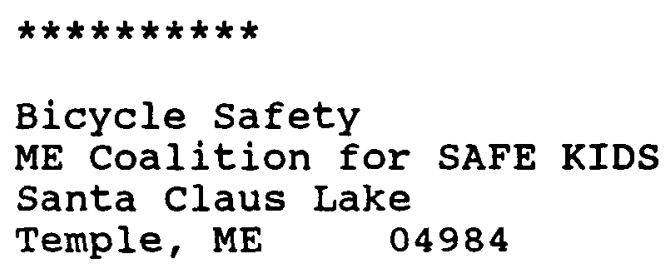

Bicycle safety

ME Coalition for SAFE KIDS

Santa Claus Lake

Temple, ME

04984

(listing continued next page) 
Contact: Robert Bull

Target: All ages
Strategy: PI\&E
Coalition: Yes
Funding: in-kind \& volunteers
Project Length: Multi-year
Geographic Area: State
Evaluation: None

\section{MARYLAND}

League of American wheeimen $190 \mathrm{~W}$ Ostend St., Suite 120 Baltimore, MD 21230

301-539-3399

Contact: Susie Jones

Target: All ages

Strategy: Aid

Coalition: Yes

Funding: Over $\$ 5000 / \mathrm{yr}$.

Project Length: Multi-year Geographic Area: Nation

Evaluation: None

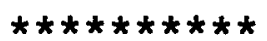

Baltimore Bicycling club 216 Longwood Rd.

Baltimore, MD 21210

301-435-6623

Contact: Robert B. Moore

Target: All ages

Strategy: Use

Coalition: No

Funding: NA

Project Length: Multi-year

Geographic Area: Region

Evaluation: None
Bike Helmet Project

MD Chpt. Amer. Acad. of Ped.

Johns Hopkins Hospital

Department of Pediatrics

$600 \mathrm{~N}$ Wolfe St., 144 CMSC

Baltimore, MD 21205

Contact: Modena Wilson, M.D.

Target: Kids, Parents

Strategy: PI\&E, Aid

Coalition: Yes

Funding: $\$ 1000-\$ 5000 / y r$.

Project Length: Multi-year

Geographic Area: State

Evaluation: Limited

$\star \star \star \star * \star * * \star *$

Shepherd Pratt Hospital

$6501 \mathrm{~N}$ Charles street

Baltimore, MD 21204

Contact: Kay Lambert

Target: Kids

Strategy: PI\&E, Distr., Use Coalition: No

Funding: NA

Project Length: 1-3 months

Geographic Area: Region

Evaluation: None

$\star * * * \star \star * \star * * *$

Injury Prevention \& Control Department of Health \& Mental Hygiene, Room 304A 201 West Preston Street Baltimore, MD 21201

$301-225-5780$

Contact: Ellen Schmidt Lynn Khoo

Target: Kids, Teens Strategy: PI\&E, Use Coalition: Yes Funding: Over $\$ 5000 / \mathrm{yr}$. Project Length: Multi-year Geographic Area: County, st. Evaluation: Limited 


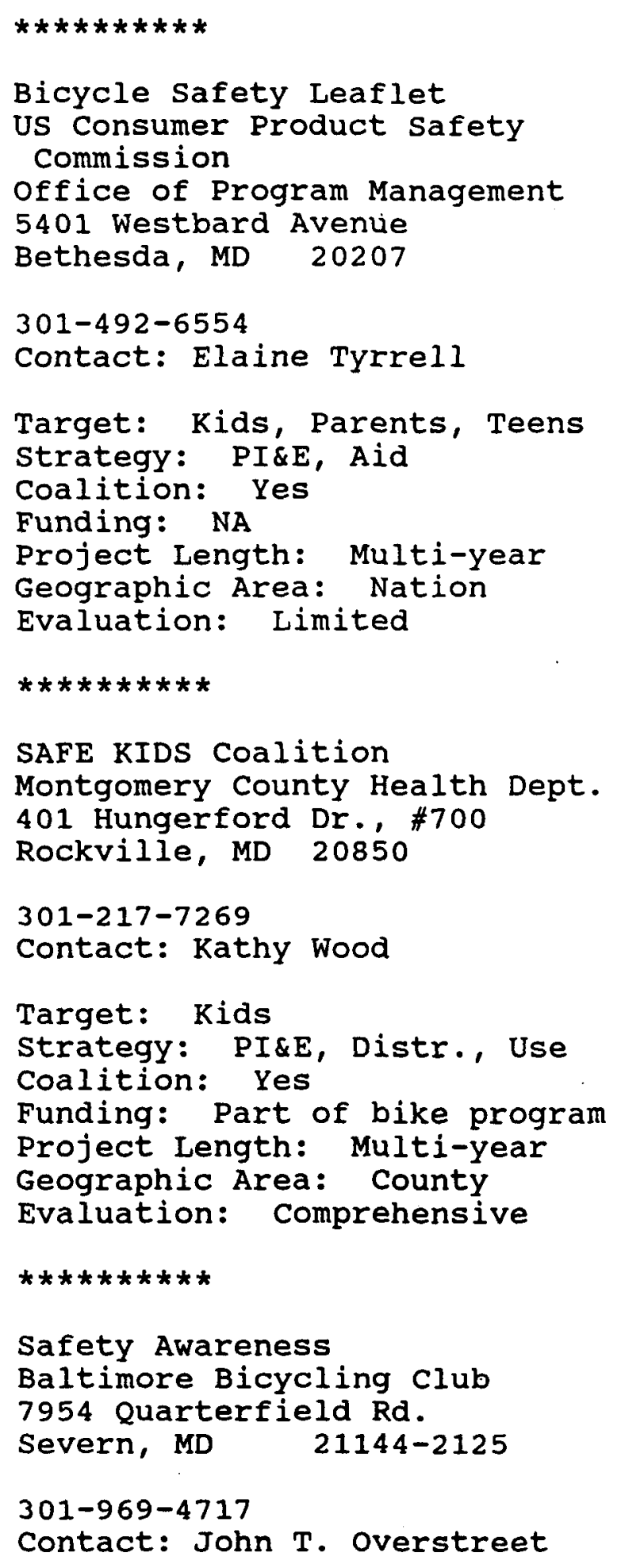

$* * * * * * * * * *$

Bicycle Safety Leaflet

US Consumer Product safety Commission

office of Program Management

5401 Westbard Avenue

Bethesda, MD 20207

301-492-6554

Contact: Elaine Tyrrell

Target: Kids, Parents, Teens Strategy: PI\&E, Aid

Coalition: Yes

Funding: NA

Project Length: Multi-year

Geographic Area: Nation

Evaluation: Limited

\footnotetext{
$* * * * * * * * * *$

SAFE KIDS Coalition

Montgomery County Health Dept. 401 Hungerford Dr., \#700

Rockvilie, MD 20850

301-217-7269

Contact: Kathy Wood

Target: Kids

Strategy: PI\&E, Distr., Use Coalition: Yes

Funding: Part of bike program Project Length: Multi-year Geographic Area: County Evaluation: Comprehensive

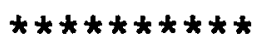

Safety Awareness

Baltimore Bicycling club

7954 Quarterfield Rd.

Severn, MD 21144-2125

301-969-4717

Contact: John T. Overstreet
}

Target: All ages

Strategy: PI\&E

Coalition: No

Funding: over $\$ 5000 / \mathrm{yr}$.

Project Length: Multi-year

Geographic Area: St., Local

Evaluation: None

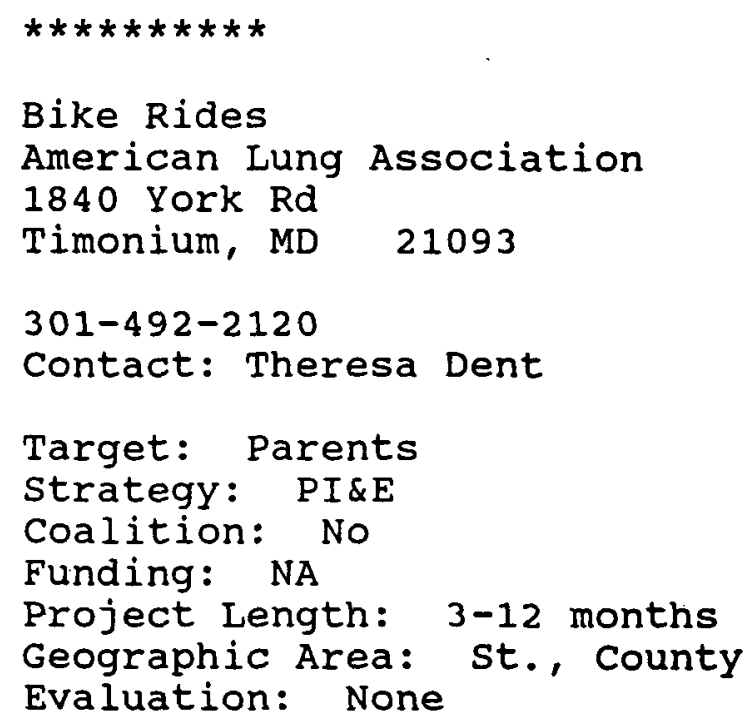

Bike Rides

American Lung Association

1840 York Rd

Timonium, MD

21093

301-492-2120

Contact: Theresa Dent

Target: Parents

Strategy: PI\&E

Coalition: No

Funding: NA

Project Length: 3-12 months

Geographic Area: st., County

Evaluation: None

\section{MASSACHUSETTS}

Department of Public Health, SCIPP

150 Tremont St, 3rd Floor

Boston, MA 02111

617-727-1246

Contact: Diane Butkus

Target: All ages

Strategy: PI\&E, Aid

Coalition: No

Funding: NA

Project Length: Multi-year

Geographic Area: State

Evaluation: None 
Marlborough Bicycle Rodeo

Saving Lives Program

City Hall

$140 \mathrm{Main}$ Street

Marlborough, MA

01752

$508-460-3764$

Contact: Alison Hartt

Target: Kids, Parents

Strategy: PI\&E, Distribution Coalition: Yes

Funding: $\$ 1000-\$ 5000 / y r$.

Project Length: 1 day/yr.

Geographic Area: Local

Evaluation: Limited

$\star \star \star \star \star \star * \star * \star *$

National Youth Sports

Foundation for Prevention of Athletic Injuries

10 Meredith Circle

Needham, MA 02192

617-449-2499

Contact: Rita Glassman

Target: All ages

Strategy: PI\&E

Coalition: Yes

Funding: NA

Project Length: Multi-year

Geographic Area: Nation

Evaluation: None

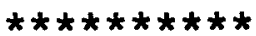

Helmet Rebate Program

Charles River Wheelmen

19 Chase Ave.

Newton, MA 02165

617-325-BIKE

Target: Adu].ts

Strategy: PJ\&E, Distribution Coalition: No

Funding: NA

Project Length: Multi-year

Geographic Area: Local

Evaluation: None $\star \star \star \star \star \star \star * * * \star$

Brockton Bike Safety Day

MA Chapter American Academy of Pediatrics

28 Baltic Avenue

North Easton, MA

02356

508-586-3600, ext 2725

Contact: Paul Schreiber, M.D.

Target: Kids, all adults

Strategy: PI\&E, Distribution

Coalition: Yes

Funding: $\$ 1000-\$ 5000 / y r$.

Project Length: Multi-year

Geographic Area: Local

Evaluation: Limited

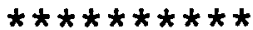

Bicycle safety Campaign

Saving Lives Program

City Hall

210 Main street

Northampton, MA

01060

413-586-6950, ext 288

Contact: Wendy Foxmyn

Target: All ages

Strategy: PI\&E, Distribution

Coalition: Yes

Funding: Less than $\$ 500 / y r$.

Project Length: Multi-year

Geographic Area: Local

Evaluation: Limited

$\star \star \star \star \star \star \star \star \star \star * *$

Project Head First

Head First Promotions

2 Grant street

P.O. Box 1746

Plainville, MA 02762

508-695-0353

Contact: George Brown

(listing continued next page) 
Target: Kids

Strategy: PI\&E, Aid

Coalition: Yes

Funding: NA

Project Length: NA

Geographic Area: Local

Evaluation: None

$\star * * * * * * * * *$

Polar Bear club

Hatherly School

72 Ann Vinal Road

Scituate, MA 02066

617-545-6790

Contact: Martin Grassie, Robert Platka

Target: Kids, Parents

Strategy: PI\&E

Coalition: Yes

Funding: in-kind \& volunteers

Project Length: Multi-year

Geographic Area: Local

Evaluation: None

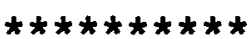

Wampatuck Schools

266 Tilden Rd

Scituate, MA 02066

617-545-1651

Contact: Jay Brabazon

Target: Kids

strategy: PI\&E

Coalition: Yes

Funding: $\$ 501-\$ 1000 / y r$.

Project Length: $1-3$ months

Geographic Area: Local

Evaluation: Limited

$\star \star \star \star \star \star \star * * * \star$

Bicycle Safety Programs Scituate Public Schools 72 Ann Vinal Rd.

Scituate, MA 02066

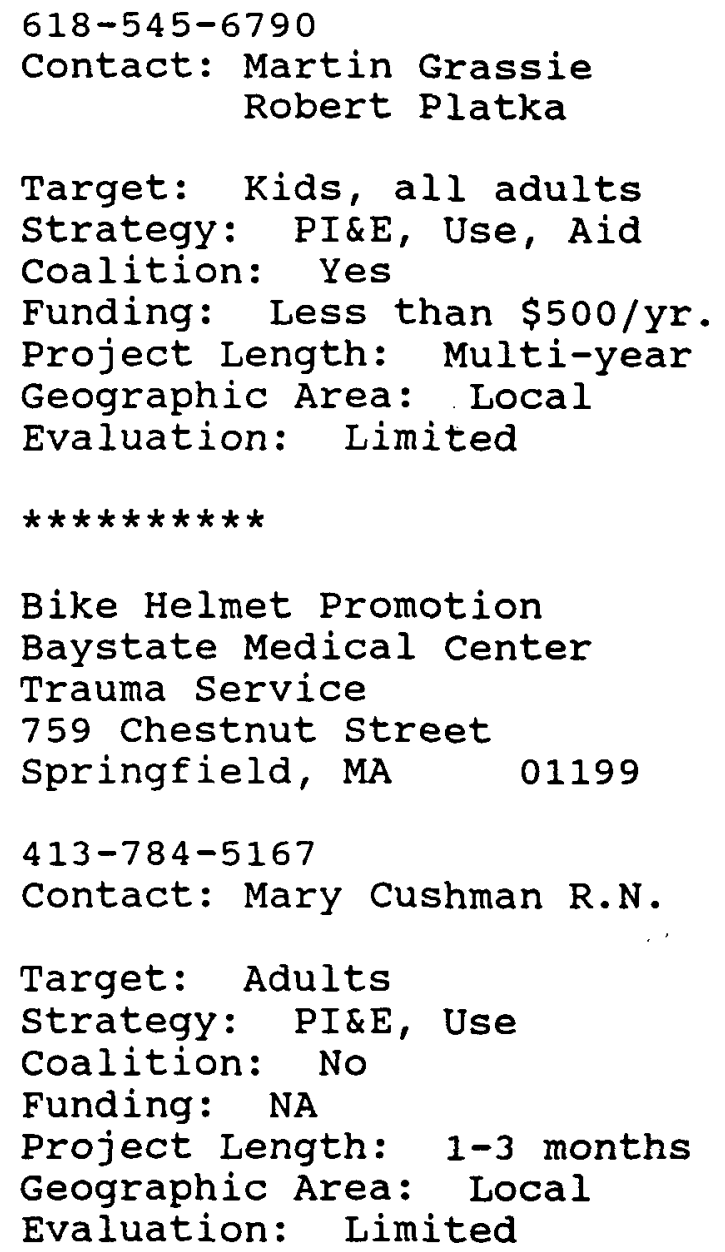

\section{MICHIGAN}

SAFE KIDS

Children's Hospital of MI Parent-Patient Education 3901 Beaubien Blvd. Detroit, MI 48201

$313-745-5658$

Contact: Patricia A. Vranesich

Target: Kids, Parents Strategy: PI\&E, Distribution Coalition: Yes

Funding: NA

Project Length: Multi-year

Geographic Area: Region

Evaluation: Limited 
Bicycle Driver Ed. Program Co. Intermediate School District 6700 Brown Lake Rd

Jackson, MI 49201

$517-787-2800$

Contact: Lisa scott

Target: Kids

Strategy: PI\&E

Coalition: Yes

Funding: $\$ 1000-\$ 5000 / \mathrm{yr}$.

Project Length: 3-12 months

Geographic Area: County

Evaluation: Limited

$\star \star \star \star \star * * * \star * \star$

Reduce Head Injury to Kids

MI Department of Public Health Health surveillance section $3423 \mathrm{~N}$. Logan

Lansing, MI 48909

517-335-8398

contact: Pat Smith

C. Michael Krecek

Target: Parents, Teens

Strategy: PI\&E, Distribution

Coalition: Yes

Funding: over $\$ 5000 / y r$.

Project Length: $1-3$ months

Geographic Area: County

Evaluation: Comprehensive

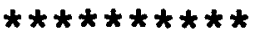

Shinn \& Associates

$2853 \mathrm{~W}$. Jolly

Okemos, MI

48864

517-332-0211

Contact: David Shinn

Target: All ages

Strategy: PI\&E, Distr., Aid Coalition: No

Funding: NA

Project Length: Multi-year

Geographic Area: Nation

Evaluation: Limited

\author{
$\star \star * \star * \star * * * *$ \\ Use Your Head, Use Your Helmet \\ Smith Middle School \\ 5835 Donaldson \\ Troy, MI 48098 \\ Contact: stuart Redpath \\ Target: Kids, Parents \\ Strategy: PI\&E, Distribution \\ Coalition: Yes \\ Funding: NA \\ Project Length: 1-3 months \\ Geographic Area: Local \\ Evaluation: Comprehensive
}

\section{MINNESOTA}

Bicycle Safety Night

Parent Advisory Committee

Armstrong School

8855 Inwood Avenue South

cottage Grove, MN 55016

Contact: Penelope Geisler

Target: Kids, all adults

Strategy: PI\&E, Distribution Coalition: Yes

Funding: in-kind \& volunteers Project Length: 3-12 months

Geographic Area: Local

Evaluation: Limited

1989 Safe Kids Campaign

MN Coalition of Bicyclists

P.O. Box 75452

st. Paul, MN 55175

Contact: Mike Miller

Target: Kids

strategy: NA

Coalition: Yes

Funding: NA

Project Length: 3-12 months

Geographic Area: State

Evaluation: None 


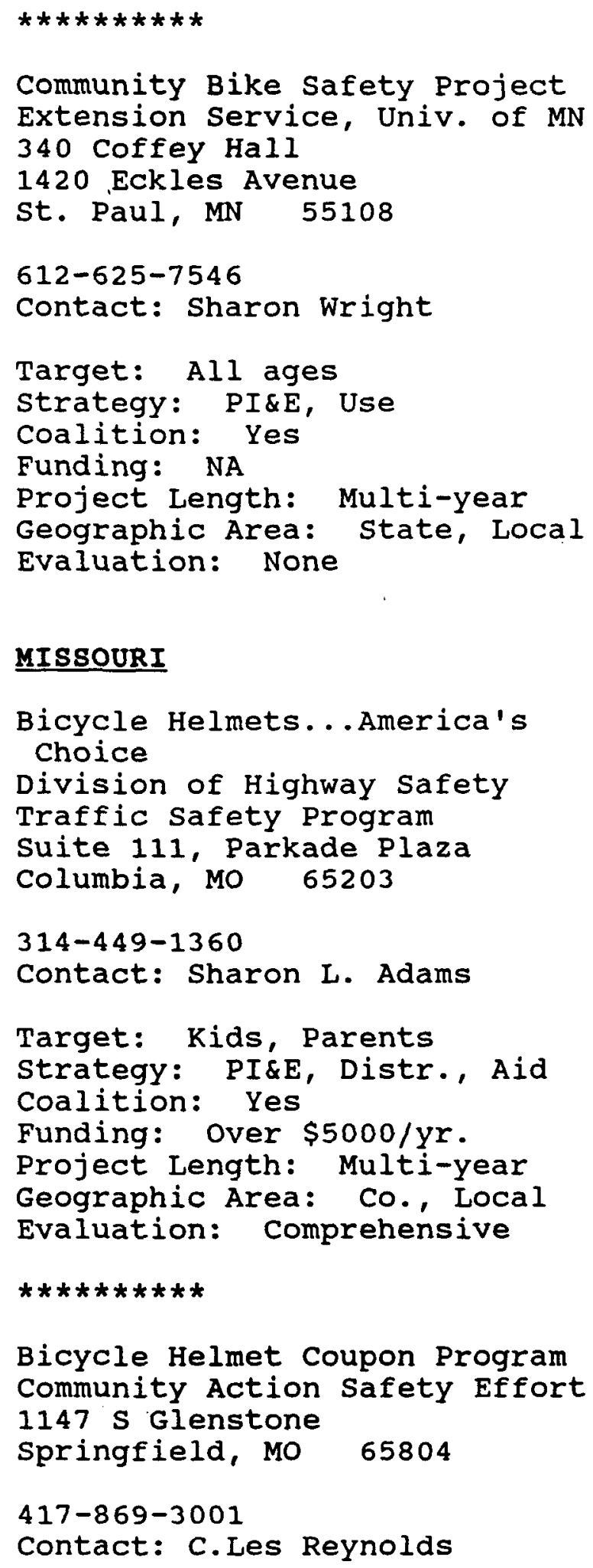

\section{MISSOURI}

Bicycle Helmets... America's Choice

Division of Highway Safety

Traffic safety Program

Suite 111, Parkade Plaza

Columbia, MO 65203

314-449-1360

Contact: Sharon L. Adams

Target: Kids, Parents

Strategy: PI\&E, Distr., Aid Coalition: Yes

Funding: over $\$ 5000 / \mathrm{yr}$. Project Length: Multi-year Geographic Area: Co., Local Evaluation: Comprehensive

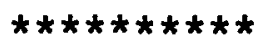

Bicycle Helmet Coupon Program Community Action safety Effort 1147 S Glenstone springfield, MO 65804

417-869-3001

Contact: C.Les Reynolds

Target: Kids

Strategy: PI\&E, Distribution Coalition: Yes

Funding: NA

Project Length: 3-12 months Geographic Area: Region

Evaluation: Limited

\section{MONTANA}

Bike Rodeo

Community crime/SAFE KIDS

151 Norris Court

Billings, MT 59105

Contact: Pam Connolly

Target: Kids

Strategy: PI\&E

Coalition: Yes

Funding: NA

Project Length: 1 day

Geographic Area: Local

Evaluation: None

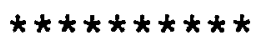

Bikecentennial

P.O. Box 8308

Missoula, MT 59807

406-721-1776

Contact: John Williams

Target: All ages

Strategy: PI\&E, Aid

Coalition: Yes

Funding: Over $\$ 5000 / y \mathrm{r}$.

Project Length: Multi-year

Geographic Area: Nation

Evaluation: Limited

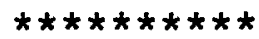

Bicycle Program

City of Missoula

435 Ryman

Missoula, MT 59802

(listing continued next page) 
406-523-4626

Contact: Mary Cheryl Hall

Target: Kids, Parents

Strategy: PI\&E, Distribution, Use, Aid

Coalition: Yes

Funding: Part of bike program

Project Length: Multi-year

Geographic Area: Local

Evaluation: Limited

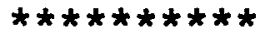 \\ Bicycle Federation \\ P.O. Box 8315 \\ Missoula, MT 59807-8315 \\ 406-543-8113 \\ Contact: Linda Tracy \\ Target: All ages \\ Strategy: PI\&E, Aid \\ Coalition: Yes \\ Funding: Part of bike program \\ Project Length: Multi-year \\ Geographic Area: Nation \\ Evaluation: Limited
}

\section{NEBRASKA}

Helmets Are Cool Contest

NE Chapter American Academy of Pediatrics

Foote Building

422 N. Hastings Ave.

Hastings, NE: 68901

Contact: stephanie Butz

Target: Kids

Strategy: PI\&E

Coalition: Yes

Funding: $\$ 1000-\$ 5000 / y r$.

Project Length: $1-3$ months

Geographic Area: State

Evaluation: Limited

\section{NEW HAMPSHIRE}

Bicycle Helmet Safety Program 25 Ballard Rd.

Derry, NH 03038

Contact: Mary Gilbert

Target: Kids, Parents

Strategy: PI\&E, Distribution Coalition: Yes

Funding: Over $\$ 5000 / \mathrm{yr}$.

Project Length: Multi-year

Geographic Area: Local

Evaluation: Comprehensive

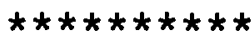

"Edubrate"

North Country Ed. Foundation

Box 194

Glen, NH 03838

Contact: Jane Abbott MacDonald

Target: Kids

Strategy: PI\&E, Distr., Use Coalition: No

Funding: NA

Project Length: 1-3 months

Geographic Area: Local

Evaluation: None

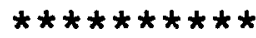

Bicycle Helmet/Safety Program Injury Prevention Center Maternal \& Child Health Dartmouth Hitchcock Medical Center

Hanover, NH 03755

603-646-7780

Contact: Mary Ann O'Connor

Target: Kids

Strategy: PI\&E, Aid

Coalition: Yes

Funding: Over $\$ 5000 / y r$.

Project Length: Multi-year

Geographic Area: State

Evaluation: Limited 


\author{
$* * * * * * * * * *$ \\ Chelsea Bike Project \\ c/o Dartmouth Hitchcock \\ Medical Center, Fowler House \\ Hanover, NH 03756 \\ $603-646-8819$ \\ Contact: Jim Sargent \\ Target: Kids \\ Strategy: PI\&E, Distribution \\ Coalition: No \\ Funding: $\$ 1000-\$ 5000 / \mathrm{yr}$. \\ Project Length: Multi-year \\ Geographic Area: Local \\ Evaluation: Limited

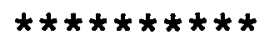 \\ Bike safety Program \\ Peterborough Elementary School \\ 17 High St \\ Peterborough, NH 03458 \\ Contact: Jane Anderson \\ Target: Kids \\ Strategy: PI\&E, Distr., Use \\ Coalition: No \\ Funding: NA \\ Project Length: Multi-year \\ Geographic Area: Local \\ Evaluation: Limited
}

\section{NEW JERSEY}

Police Bicycle Rodeo

City Police Department

500 Mill Road

Absecon, NJ 08201

Contact: Lee w. Pattison

Target: Kids

Strategy: PI\&E, Distribution

Coalition: Yes

Funding: NA

Project Length: 1 day

Geographic Area: Local

Evaluation: Comprehensive

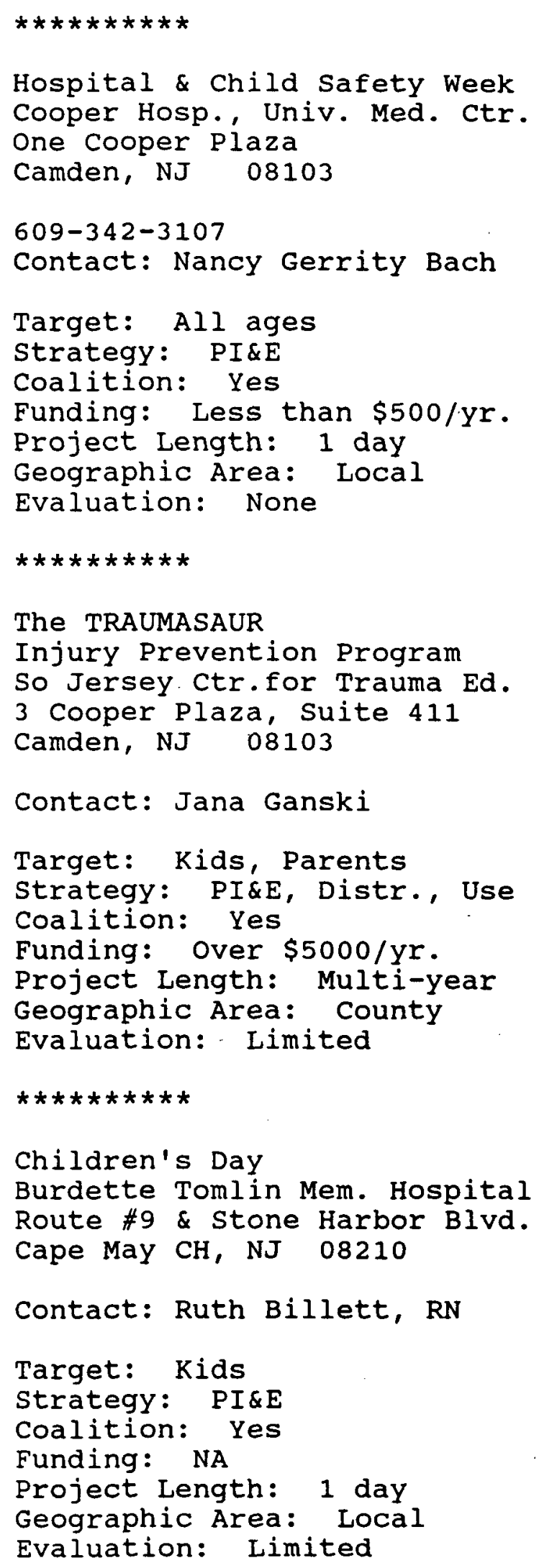

Hospital \& Child Safety Week Cooper Hosp., Univ. Med. Ctr. One Cooper Plaza

Camden, NJ 08103

609-342-3107

Contact: Nancy Gerrity Bach

Target: All ages

Strategy: PI\&E

Coalition: Yes

Funding: Less than $\$ 500 / y r$.

Project Length: 1 day

Geographic Area: Local

Evaluation: None

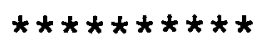

The TRAUMASAUR

Injury Prevention Program

So Jersey Ctr.for Trauma Ed.

3 Cooper Plaza, Suite 411

Camden, NJ 08103

Contact: Jana Ganski

Target: Kids, Parents

Strategy: PI\&E, Distr., Use Coalition: Yes

Funding: over $\$ 5000 / y r$.

Project Length: Multi-year

Geographic Area: County

Evaluation: Limited 


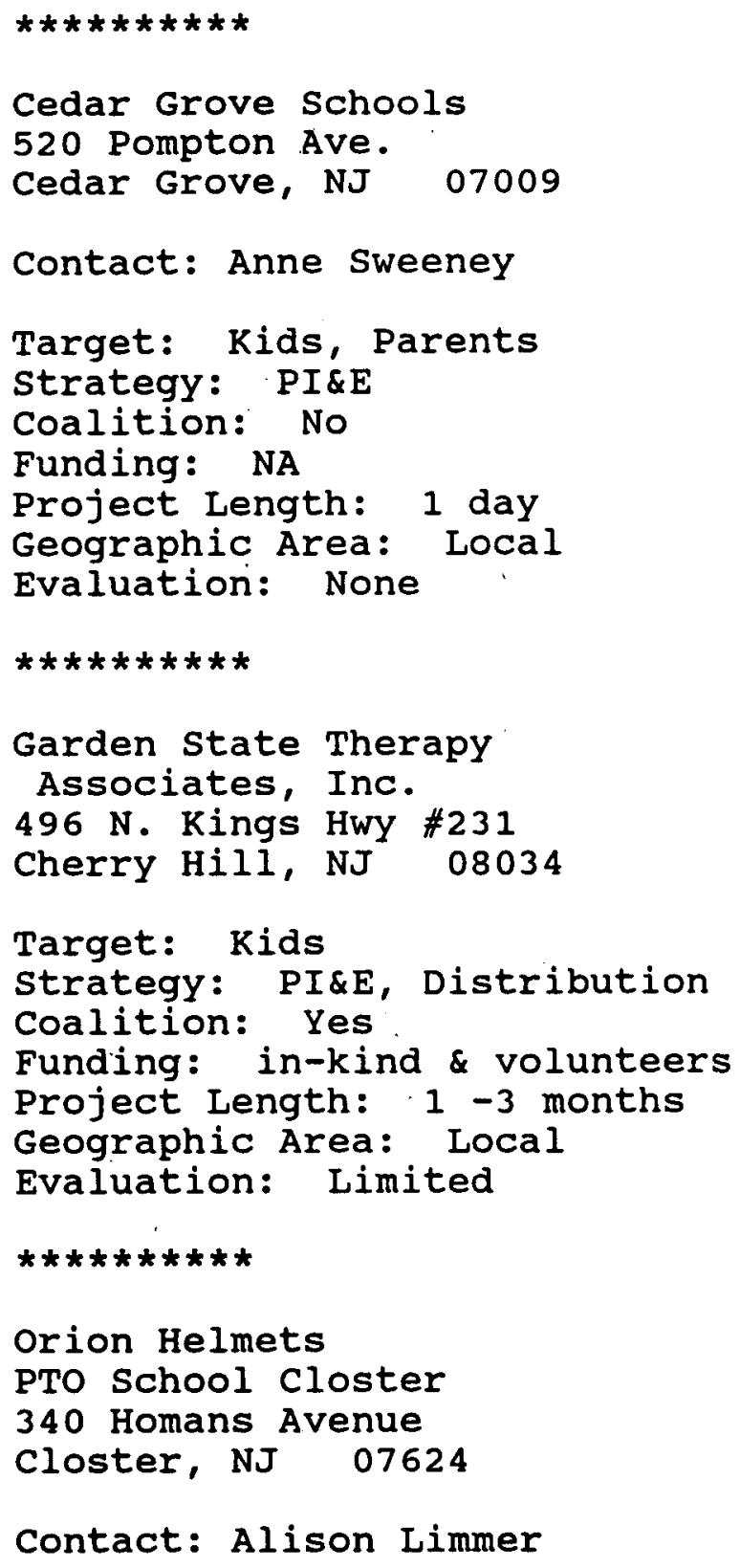

Target: Kids Strategy: PI\&E, Distribution Coalition: Yes

Funding: in-kind \& volunteers Project Length: $1-3$ months Geographic Area: Local

Evaluation: Limited

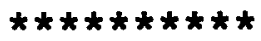

Orion Helmets

PTO School Closter

340 Homans Avenue

closter, NJ 07624

Contact: Alison Limmer

Target: All ages

Strategy: PI\&E, Distribution Coalition: No

Funding: NA

Project Length: Multi-year Geographic A.rea: Local

Evaluation: Limited
NJ Safety council

6 Commerce Drive

Cranford, NJ 07016

201-272-7712

Contact: Mary Ann Zaleski

Target: Kids, Parents

Strategy: PI\&E

Coalition: No

Funding: Part of bike program Project Length: Multi-year Geographic Area: State Evaluation: None

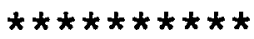

Volunteer Project

c/o NJ Safety council

6 Commerce Dr.

Cranford, NJ 07016

201-272-7712

Contact: Mary Ann Zaleski

Target: Kids, Parents

Strategy: PI\&E

Coalition: No

Funding: NA

Project Length: $1-3$ months Geographic Area: Local

Evaluation: None

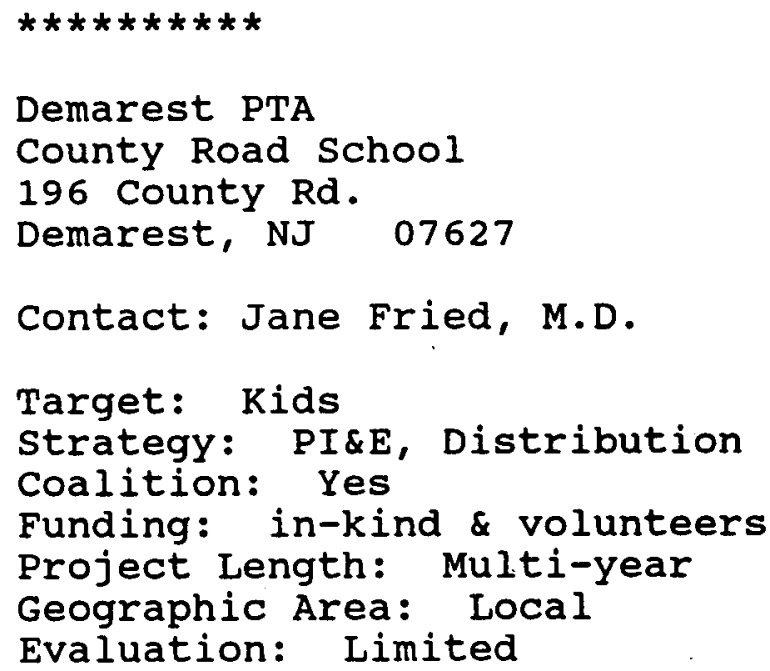


Essex Fells PTA

Essex Fells School District 102 Hawthorne Rd., P.O. Box 68 Essex Fells, NJ 07021

Contact: Betsy Saksen

Target: Kids

Strategy: PI\&E, Distribution Coalition: Yes

Funding: in-kind \& volunteers Project Length: $1-3$ months Geographic Area: Local

Evaluation: None

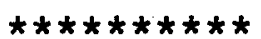

Bicycle Helmet Program

W. Essex Community Health Ser. 122 Clinton Rd.

Fairfield, NJ 07004

Contact: Augie Sabia

Target: Kids

Strategy: PI\&E, Distribution Coalition: Yes

Funding: NA

Project Length: Multi-year

Geographic Area: Local

Evaluation: Limited

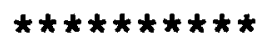

Use Your Head - Be Head Smart

AAA NJ Automobile Club

\#1 Hanover Rd.

Florham Park, NJ 07932-1888

Contact: Paul F. Kielblock

Target: All ages

Strategy: PI\&E, Distribution Coalition: Yes

Funding: NA

Project Length: Multi-year

Geographic Area: st., Region

Evaluation: Limited
Glassboro Intermediate School North Delsea Dr. Glassboro, NJ 08028

Target: Kids

Strategy: PI\&E

Coalition: No

Funding: NA

Project Length: NA

Geographic Area: Local

Evaluation: None

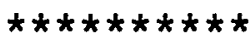

Bike Rodeo

Lawrence Elementary PTO

40 Craven La.

Lawrenceville, NJ 08648

Contact: Pat Scott-Buzi

Target: Kids

Strategy: PI\&E, Distribution Coalition: No

Funding: in-kind \& volunteers

Project Length: 1 day

Geographic Area: Local

Evaluation: Limited

$\star \star \star * \star * * * * *$

Bicycle Safety Rodeo 1991

st. Lawrence Rehab Center

2381 Lawrenceville Road

Lawrenceville, NJ 08684

609-896-9500, ext 319

Contact: Bill Marone

Target: Kids

Strategy: PI\&E

Coalition: Yes

Funding: $\$ 1000-\$ 5000 / \mathrm{yr}$.

Project Length: 1 day

Geographic Area: Local

Evaluation: Limited 
Bike Safety \& Helmet Campaign Madison Health Department Hartley Dodge Memorial Kings Road

Madison, NJ 07940

201-593-3059

Contact: Christine Shesler

Target: Kids, Parents, Teens Strategy: PI\&E, Distr., Use Coalition: Yes Funding: Less than $\$ 500 / \mathrm{yr}$. Project Length: 3 - 12 months Geographic Area: Local Evaluation: Comprehensive

$\star \star * \star * \star * * * *$

A Safer Route Somerset County Association for Retarded Citizens

141 South Main St. Manville, NJ 08835

Target: Kids Strategy: FI\&E, Distr., Use Coalition: No

Funding: over $\$ 5000 / y r$. Project Length: Multi-year Geographic Area: County Evaluation: Comprehensive

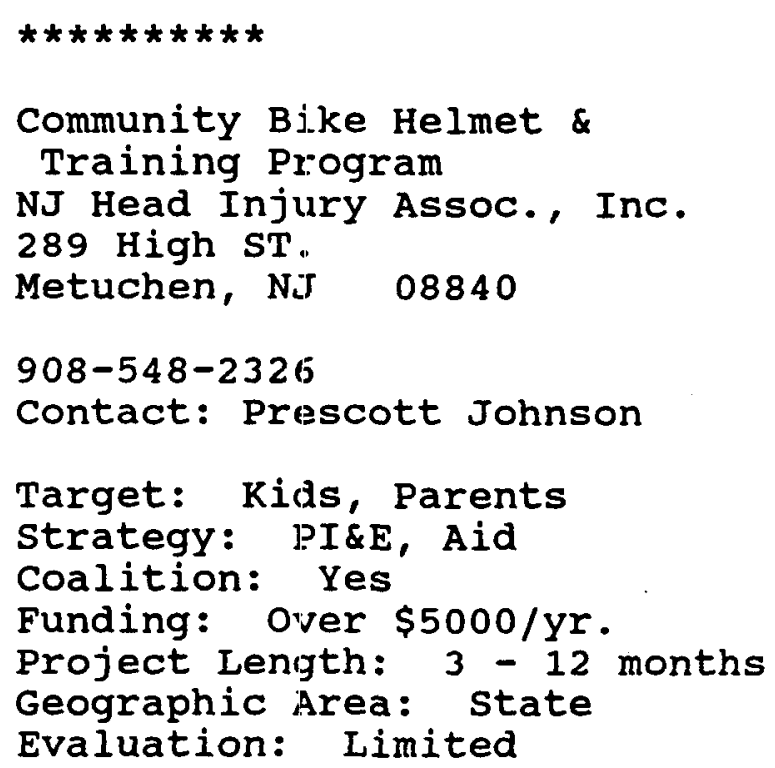

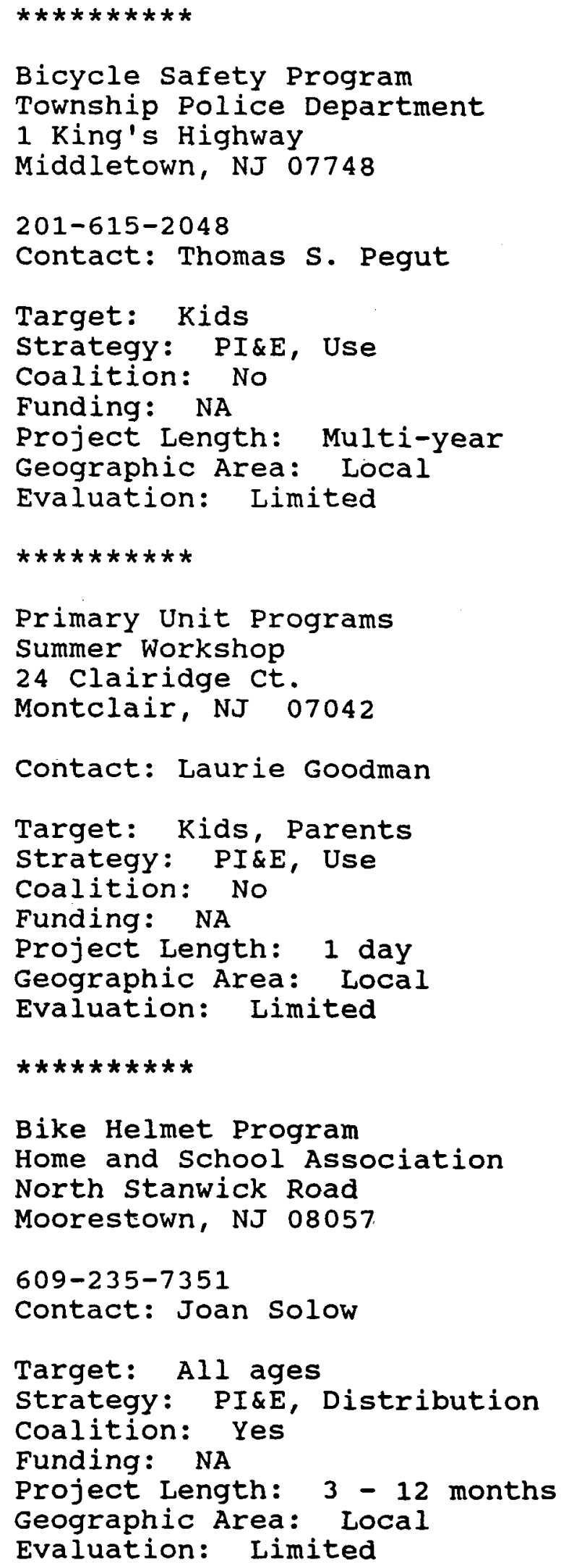

Bike Helmet Program Home and School Association North Stanwick Road Moorestown, NJ 08057 .

609-235-7351

Contact: Joan Solow

Target: All ages Strategy: PI\&E, Distribution Coalition: Yes

Funding: NA

Project Length: $3-12$ months Geographic Area: Local

Evaluation: Limited 


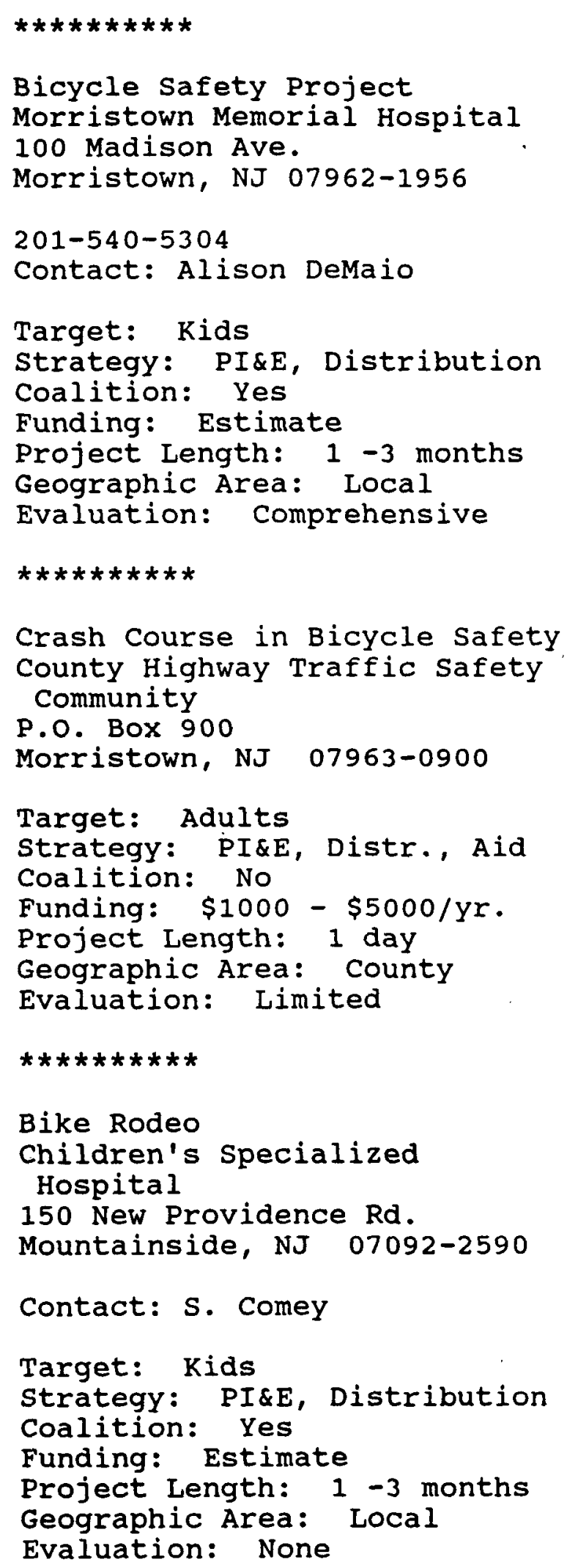

Safe Kids/Child Health/4-H Rutgers Cooperative Extension 4-H Youth Development P.O. Box 231, Waller Hall New Brunswick, NJ 08903

908-932-9704

Contact: Frank O'Hara

Target: All ages Strategy: PI\&E, Distr., Use Coalition: Yes

Funding: Over $\$ 5000 / \mathrm{yr}$. Project Length: Multi-year Geographic Area: State Evaluation: Limited

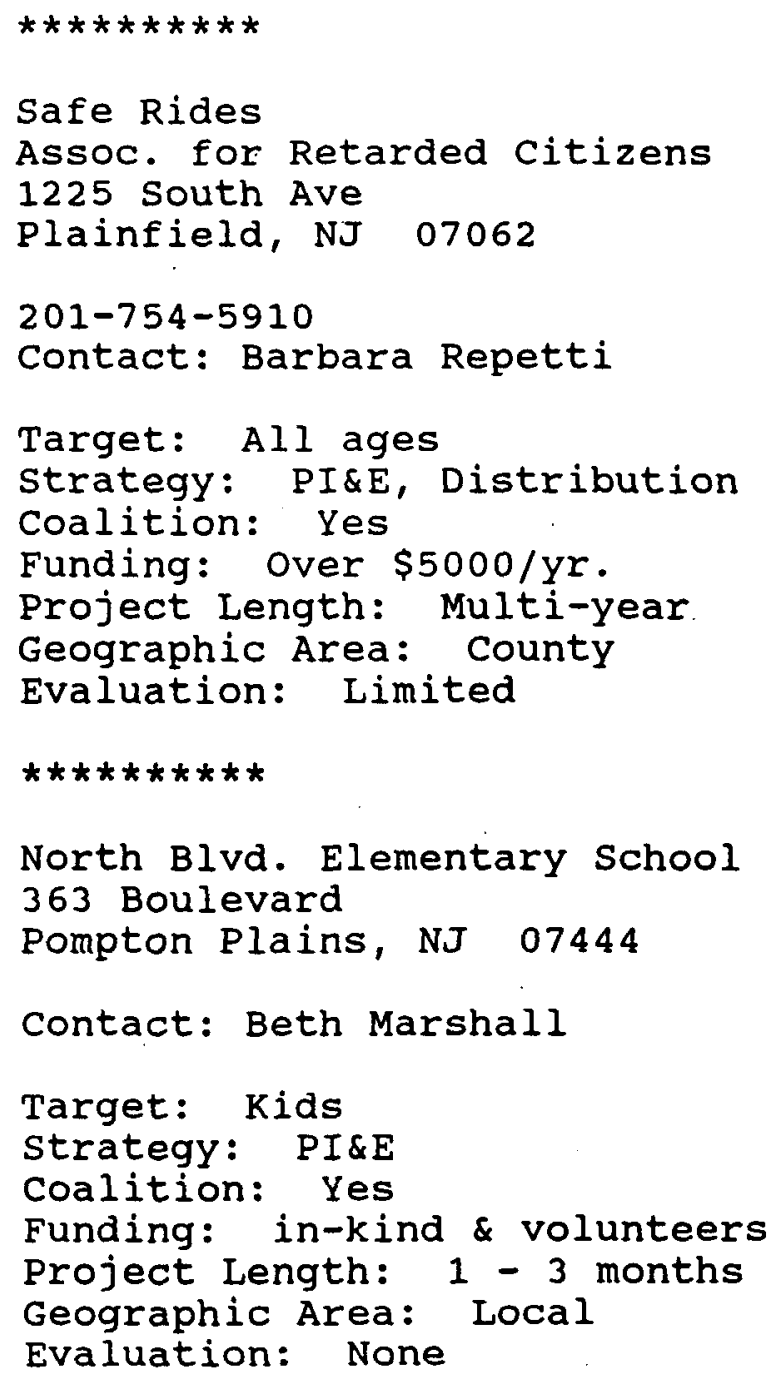

North Blvd. Elementary School 363 Boulevard 


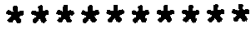

Bicycle Helmet: Ads

American Re-Insurance Company 555 College Road East

Princeton, NJ 08542

Contact: Teresse Rosenthal

Target: Parents

Strategy: PI\&E

Coalition: Yes

Funding: Overe $\$ 5000 / \mathrm{yr}$.

Project Length: 1 - 3 months

Geographic Area: Nation

Evaluation: Limited

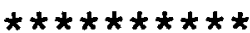

Bike Safety School Programs Township of Randolph

502 Millbrook Avenue

Randolph, NJ 07869

Contact: Craig D. Wolfson

Target: Kids

Strategy: PI\&E, Distribution Coalition: Yes

Funding: NA

Project Length: Multi-year

Geographic Area: Local

Evaluation: Limited

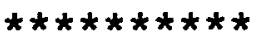

PTA

534 Elizabeth

River Vale, NJ 07675

Contact: Linda Rothschild

Target: Kids

Strategy: PI\&E, Distribution coalition: No

Funding: NA

Project Length: Multi-year

Geographic Alrea: Local

Evaluation: Limited
Traffic Safety Division

61 Main st.

South River, NJ 08882

$908-254-1150$

Contact: Sgt. William schmidt

Target: Kids

Strategy: PI\&E

Coalition: No

Funding: NA

Project Length: 1 day

Geographic Area: Local

Evaluation: None

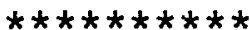

Ocean Co. Traffic Safety comm. CN 2191 Hooper Avenue

Toms River, NJ 08754

201-929-2130

Contact: Roden S. Lightbody

Target: All ages

Strategy: PI\&E

Coalition: Yes

Funding: over $\$ 5000 / \mathrm{yr}$.

Project Length: Multi-year

Geographic Area: Local, Co.

Evaluation: Limited

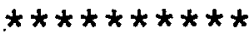

Department of Transportation 1035 Parkway Ave.

Trenton, NJ 08625

609-530-8048

Contact: William Feldman

Target: All ages

Strategy: PI\&E, Aid

Coalition: No

Funding: Part of bike program

Project Length: Multi-year

Geographic Area: State

Evaluation: None 
Office of Prevention

Department of Human Services

222 s. Warren st., CN \#700

Trenton, NJ 08625

$609-984-3349$

Contact: Mary Buchanan

Target: Adults

Strategy: PI\&E, Distribution Coalition: No

Funding: NA

Project Length: NA

Geographic Area: State

Evaluation: Comprehensive

\section{NEW MEXICO}

Helmets \& Bikes Together

Public Health Nurses/Clerks county Health office

111 Stanford Dr., NE

Albuquerque, NM 87106

Contact: Judy Renner RN, PHW

Target: Kids

Strategy: PI\&E

Coalition: Yes

Funding: $\$ 1000-\$ 5000 / \mathrm{Yr}$.

Project Length: Multi-year

Geographic Area: Local

Evaluation: Limited

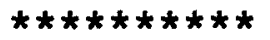

No Helmet/ No Brains

Dona Ana Co. Public Health

$715 \mathrm{E}$. Idaho street

Las Cruces, NM 88001

$505-524-6000$

Contact: Paul L. Jewell

Target: Kids, Parents

Strategy: PI\&E

Coalition: Yes

Funding: $\$ 1000-\$ 5000 / y r$.

Project Length: 1 - 3 months

Geographic Area: State

Evaluation: None
}

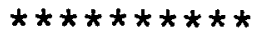 \\ SAFE KIDS Coalition \\ Department of Health \\ 1190 st. Francis Drive \\ Santa Fe, NM 87502 \\ Contact: Donna Dossey \\ Target: Kids, Parents \\ Strategy: PI\&E, Distribution \\ Coalition: Yes \\ Funding: $\$ 1000-\$ 5000 / y r$. \\ Project Length: Multi-year \\ Geographic Area: State \\ Evaluation: Limited
}




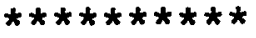 \\ Monroe County Bicycle Helmet \\ coalition \\ Gr's Traffic safety committee \\ S. Swan St. Bldg, Rm 414 \\ Empire state Plaza \\ Albany, NY 12228 \\ Contact: Mary Jane McGuire \\ Target: All ages \\ Strategy: PI\&E, Distr., Aid \\ Coalition: Yes \\ Funding: Part of bike program \\ Project Length: Multi-year \\ Geographic Area: State, Local \\ Evaluation: Comprehensive

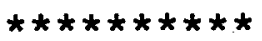 \\ Bicycle Rodeo \\ Health Care Plan \\ 900 Guaranty Building \\ Buffalo, NY 14202 \\ Contact: Judson Mead \\ Target: Kids \\ Strategy: PI\&E, Distribution \\ Coalition: No \\ Funding: $\$ 1000-\$ 5000 / \mathrm{yr}$. \\ Project Length: 1 day \\ Geographic Area: County \\ Evaluation: Limited
}

$\star * \star \star \star \star \star * \star * \star$

NY League of American Wheelmen 6 Santa Lucia court clifton Park, NY 12065

518-371-7059

Contact: Herb Alfasso

Target: Kids;

Strategy: PI\&E, Use

Coalition: Yes

Funding: NA

Project Length: Multi-year

Geographic Area: Local

Evaluation: None

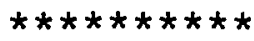

4-H Bike Safety Ed. Program

Cooperative Extension

Cornell University

328 Riley, Robb Hall

Ithaca, NY 14853

607-255-2498

Contact: Lois Chaplin

Target: Kids

Strategy: PI\&E, Aid

Coalition: Yes

Funding: NA

Project Length: Multi-year

Geographic Area: State, Local

Evaluation: None

$\star * * * * * * \star * *$

Bicycle Helmet Loaner Program

Town of Brookhaven

3233 Rt. 112

Medford, NY 11763

$516-451-6480$

Contact: Paul Rogalle

Target: Kids, Parents

Strategy: PI\&E, Distribution

Coalition: Yes

Funding: Over $\$ 5000 / y r$.

Project Length: Multi-year

Geographic Area: Local

Evaluation: Comprehensive

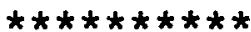

Bicycle Helmet Safety

Coalition

Rochester Pediatric Society

59 B Monroe Ave.

Pittsford, NY 14534

$716-271-1313$

Contact: Donald Eldridge, M.D.

(listing continued next page) 
Target: All ages

Strategy: PI\&E, Distribution Coalition: Yes

Funding: NA

Project Length: 3 - 12 months Geographic Area: Co., Region

Evaluation: Comprehensive

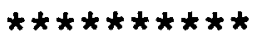

Bicycle Helmet Safety Project NY Chapter American Academy of Pediatrics

125 Lattimore Rd

Rochester, NY 14620

Contact: Anne Francis, M.D.

Target: Kids, Parents

Strategy: PI\&E, Distribution Coalition: Yes

Funding: over $\$ 5000 / \mathrm{Yr}$.

Project Length: Multi-year

Geographic Area: State, Co.

Evaluation: Limited

$\star \star * * * * * * * *$

Snell B-90 standard

Snell Memorial Foundation

P.O. Box 493

St. James, NY 11780

516-862-6440

Contact: Edward Becker

Target: All ages

strategy: PI\&E, Aid

Coalition: No

Funding: NA

Project Length: Multi-year

Geographic Area: Nation

Evaluation: Comprehensive

\section{NORTH CAROLINA}

Bicycle Helmet committee Thoms Hospital one Rotary Dr. Asheville, NC
Contact: Nancy Seymour

Target: All ages

Strategy: PI\&E, Distribution Coalition: Yes

Funding: Less than $\$ 500 / \mathrm{yr}$. Project Length: 3 - 12 months Geographic Area: Co., Local Evaluation: Limited

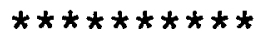

Charlotte-Mecklenburg Hospital Authority

P.O. Box 32861

Charlotte, NC 28232-2861

$704-355-4034$

Contact: Richard Gentsch

Target: Kids, Parents

Strategy: PI\&E, Distribution

Coalition: Yes

Funding: NA

Project Length: Multi-year

Geographic Area: Local

Evaluation: Limited

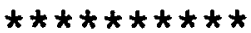

2nd Annual PD Bike Rodeo

Police Department

300 West Washington st.

Greensboro, NC 27402-3136

919-373-2216

Contact: Tony Aprile

Target: Kids, Parents

strategy: PI\&E

Coalition: Yes

Funding: Less than $\$ 500 / y x$.

Project Length: 1 day/yr

Geographic Area: Local

Evaluation: Limited 
Bicycle Safety \& Helmet

promotion Project

County Health Department

1347 Spartanburg Hwy

Hendersonville, NC 28792

Contact: Terri Sparks

Target: Kids, Parents

Strategy: PI\&E, Distribution

Coalition: Yes

Funding: NA

Project Length: 3 - 12 months

Geographic Area: County

Evaluation: Limited

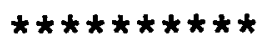

Local Safe Kids coalition

Catawba Memorial Hospital

810 Fairgrove Church Rd.

Hickory, NC 28602

704-465-5506

Contact: Janet: Moss

Target: Kids

Strategy: PI\&E, Distribution

Coalition: Yes

Funding: $\$ 1000-\$ 5000 / \mathrm{Yr}$.

Project Length: Multi-year

Geographic Area: County

Evaluation: Iimited

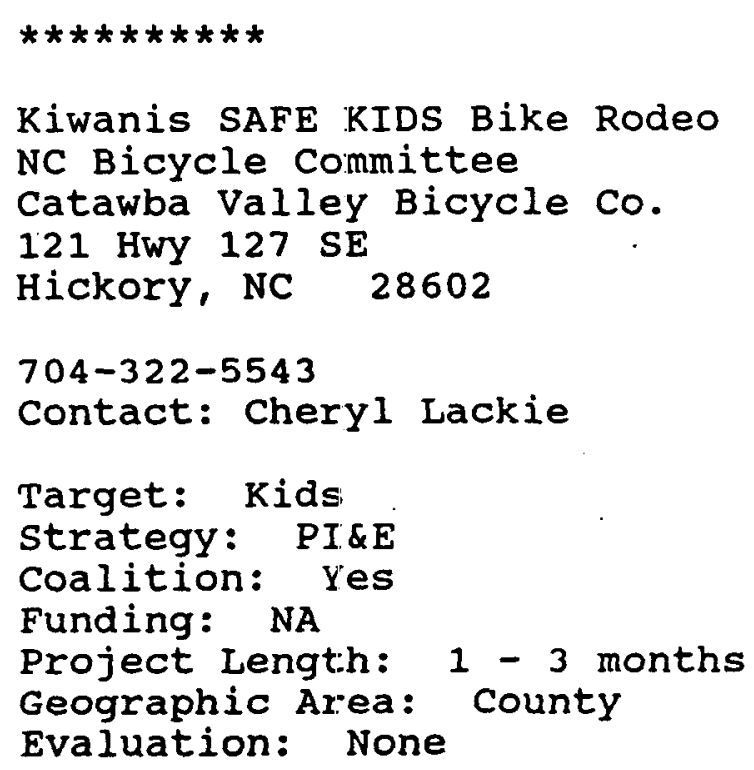

Kiwanis SAFE KIDS Bike Rodeo NC Bicycle Committee

Catawba Valley Bicycle Co.

121 HWY 127 SE

Hickory, NC 28602

$704-322-5543$

Contact: Cheryl Lackie

Target: Kids

strategy: PI\&E

Coalition: Yes

Funding: NA

Project Length: 1 - 3 months

Geographic Area: county

Evaluation: None

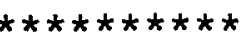 \\ Bicycle Helmet Campaign \\ Bicycle Program \\ Department of Transportation \\ P.O. Box 25201 \\ Raleigh, NC 27611 \\ 919-733-2804 \\ Contact: Mary Meletiou \\ Target: All ages \\ Strategy: PI\&E, Aid \\ Coalition: Yes \\ Funding: Over $\$ 5000 / \mathrm{yr}$. \\ Project Length: Multi-year \\ Geographic Area: State \\ Evaluation: Comprehensive \\ $\star \star * \star \star * \star * \star * \star$ \\ Pitt County Bike Helmet \\ Promotion Project \\ Maternal \& Child Health \\ Department of Environment, \\ Health \& Natural Resources \\ P.O. Box 27687 \\ Raleigh, NC 27611-7687 \\ $919-733-3816$ \\ Target: Kids \\ Strategy: PI\&E, Distr., Aid \\ Coalition: No \\ Funding: Over $\$ 5000 / y r$. \\ Project Length: Multi-year \\ Geographic Area: County \\ Evaluation: Comprehensive \\ $* * * * * * * * \star *$ \\ Department of Environment, \\ Health \& Natural Resources \\ Injury Control, Div. of Health \\ P.O. Box 27687 \\ Raleigh, NC 27611-7687 \\ 919-733-3732 \\ Contact: Diana Grey \\ (1isting continued next page)
}


Target: All ages

Strategy: PI\&E, Aid

Coalition: Yes

Funding: over $\$ 5000 / y r$.

Project Length: Multi-year

Geographic Area: State, Local

Evaluation: Comprehensive

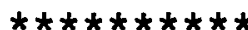

Bicycle Helmet Promotion County Health Department P.O. Box 579

Washington, NC 27889

Target: Kids

Strategy: PI\&E

Coalition: Yes

Funding: in-kind \& volunteers

Project Length: 1 - 3 months

Geographic Area: County

Evaluation: None

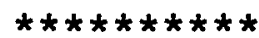

Happy Helmets To You

County Health Department 2029 South 17th St.

wilmington, NC 28401

$919-251-3200$

Contact: Denise Teachey

Target: Kids

Strategy: PI\&E, Distribution

Coalition: Yes

Funding: Over $\$ 5000 / \mathrm{yr}$.

Project Length: Multi-year

Geographic Area: Local

Evaluation: Comprehensive

Bicycle Helmet Promotion County Health Department Box 457

Yadkinville, NC 27055
Target: Kids, Teens

Strategy: PI\&E, Distribution Coalition: Yes

Funding: $\$ 1000-\$ 5000 / \mathrm{yr}$.

Project Length: 1 - 3 months

Geographic Area: county

Evaluation: Comprehensive

\section{OHIO}

Cleveland Clinic Foundation

1 Clinic Center

9500 Euclid Ave.

Cleveland, OH 44195-5045

Contact: Michael Macknin, M.D.

Target: Kids

Strategy: PI\&E, Distr., Use

Coalition: Yes

Funding: $\$ 1000-\$ 5000 / Y r$.

Project Length: Multi-year

Geographic Area: Co., Local

Evaluation: Comprehensive

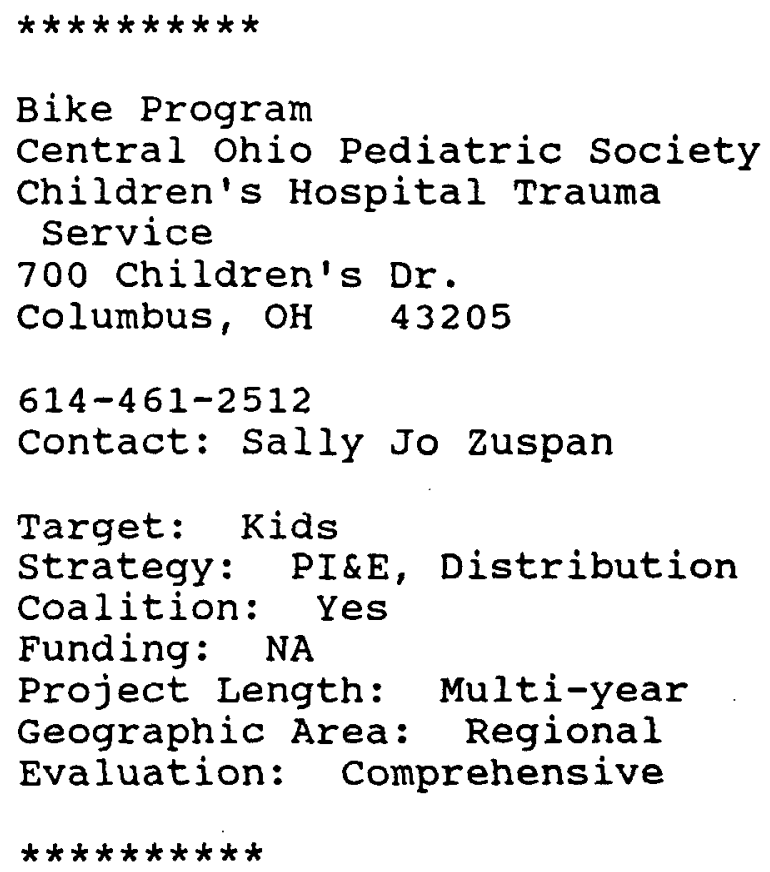

Bike Program

Central Ohio Pediatric Society

Children's Hospital Trauma

Service

700 Children's Dr.

Columbus, OH 43205

614-461-2512

Contact: Sally Jo Zuspan

Target: Kids

Strategy: PI\&E, Distribution

Coalition: Yes

Funding: NA

Project Length: Multi-year

Geographic Area: Regional

Evaluation: Comprehensive

$\star \star \star * \star * * * \star *$ 
Department of Health

Bureau of Environmental Health $246 \mathrm{~N}$ High St

PO Box 118

Columbus, $\mathrm{OH}$

$43266-0118$

614-466-1450

Contact: Michael Moser

Target: All ages

Strategy: PI\&E

Coalition: Yes

Funding: NA

Project Length: Multi-year

Geographic Area: state

Evaluation: None

\footnotetext{
$* * * * * * * * * *$

Bicycle Helmet Safety Campaign

oH National Head Injury

Foundation

751 Northwest Blvd.

Columbus, $\mathrm{OH} \quad 43212$

Contact: Suzanne Minnich

Target: Kids

Strategy: PI\&E, Distr., Use Coalition: Yes

Funding: Over $\$ 5000 / y r$.

Project Lengt:h: 3 - 12 months Geographic Area: Local

Evaluation: Limited

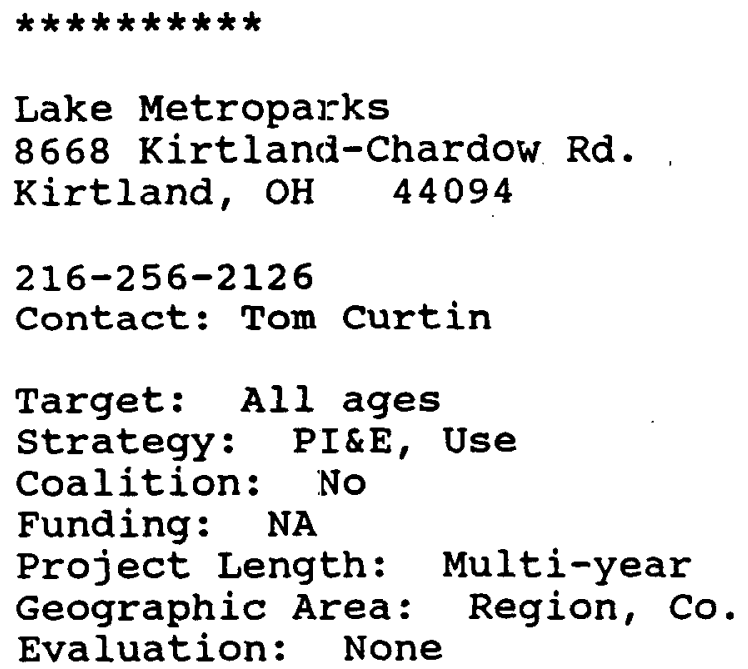

Lake Metroparks

8668 Kirtland-Chardow Rd.

Kirtland, $\mathrm{OH} \quad 44094$

216-256-2126

Contact: Tom curtin

Target: All ages

Strategy: PI\&E, Use

Coalition: No

Funding: NA

Project Length: Multi-year

Geographic Area: Region, Co.

Evaluation: None

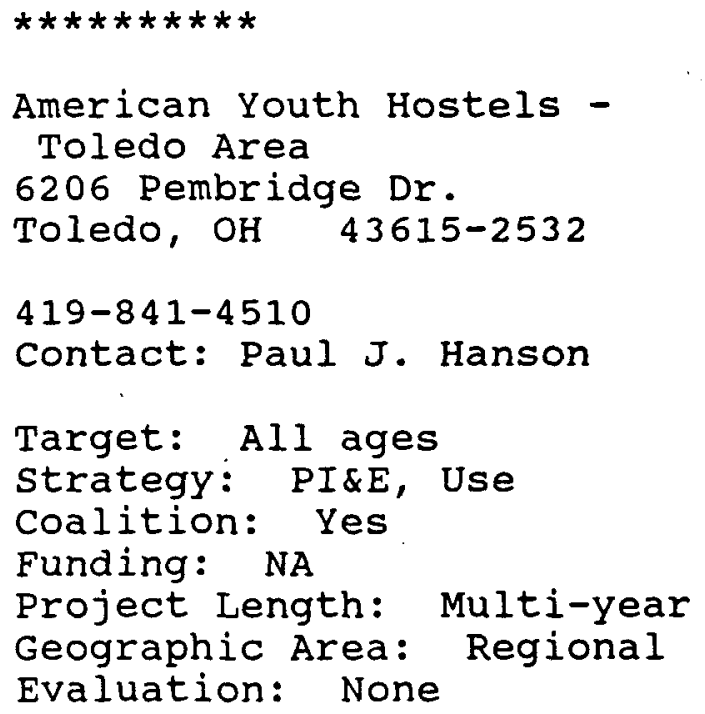

\section{ORLAHOMA}

Holiday Helmet Sale

Health Department

Injury Epidemiology Division $1000 \mathrm{NE}$ loth

oklahoma city, OK 73152

405-271-3430

Contact: Shelli stidham

Target: All adults

Strategy: PI\&E, Distribution Coalition: Yes

Funding: in-kind \& volunteers Project Length: 1 day

Geographic Area: Local

Evaluation: None

$\star \star * * * * * \star * \star$

Safe Kids coalition

Children's Hospital of OK

Center for Injury Prevention

P.O. Box 26307

Oklahoma City, OK 73126

405-271-5695

Contact: Martha Collar

(listing continued next page) 
Target: Kids, Parents, Teens Strategy: PI\&E, Distribution Coalition: Yes

Funding: Over $\$ 5000 / y r$.

Project Length: Multi-year

Geographic Area: Local, st.

Evaluation: Comprehensive

\section{OREGON}

Tough Talk About Saving Your Life

Emmanuel Hosp. \& Health Center

Life Flight Nurses

2801 N. Gantenbein Ave.

Portland, OR 97227

Contact: Joanne Fairchild

Target: All ages

Strategy: PI\&E, Distribution

Coalition: Yes

Funding: Over $\$ 5000 / y r$.

Project Length: Multi-year

Geographic Area: St., Local

Evaluation: Comprehensive

\section{PENNSYLVANIA}

Bicycle Safety Rodeos

Wayne Memorial Hospital

601 Park st.

Honesdale, PA 18431

Contact: Ellen Bradbury

Target: Kids

Strategy: PI\&E, Distribution

Coalition: Yes

Funding: NA

Project Length: $1-3$ months

Geographic Area: Region

Evaluation: Comprehensive

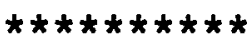

Bike Smart

PA American Trauma Society

6706 Carlisle Pike

Mechanicsburg, PA 17055
$717-766-1616$

Target: All ages

Strategy: PI\&E, Distribution

Coalition: Yes

Funding: NA

Project Length: Multi-year

Geographic Area: state

Evaluation: Limited

Annual Bicycle Helmet Drive

Harrisburg Bicycle Club

P.O. Box 190

New Cumberland, PA 17070

Target: All ages

Strategy: PI\&E, Distribution

Coalition: No

Funding: NA

Project Length: Multi-year

Geographic Area: Region

Evaluation: Limited

$\star * \star \star \star * \star * * *$

Traffic Safety Ed. Project County Health Department

Penn West Office Bldg

907 West Street

Pittsburgh, PA 15221

$412-247-7810$

Contact: Janet Valenta

Target: Kids, Parents

Strategy: PI\&E, Distribution Coalition: Yes

Funding: NA

Project Length: Multi-year

Geographic Area: County

Evaluation: Comprehensive

Bicycle Safety Rodeos

Police Citizen's Council

151 Odette st

Pittsburgh, PA 15227

(listing continued next page) 
Contact: Carol Anthony

Target: Kids

Strategy: PI\&E

Coalition: Yes

Funding: $\$ 1000-\$ 5000 / Y r$.

Project Length: 3 - 12 months

Geographic Area: Region

Evaluation: None

Helmets! The Pros Wear Them Allegheny General Hospital 320 East North Ave.

Pittsburgh, PA 15212-9986

412-323-5183

Contact: DeAnn Aston

Target: Kids, all adults Strategy: PI\&E, Distribution Coalition: Yes

Funding: over $\$ 5000 / \mathrm{yr}$.

Project Length: Multi-year

Geographic Area: County

Evaluation: Comprehensive

\section{RHODE ISLAND}

RI \& Providence Plantation Department of Health Three Capitol Hill, Room 408 Providence, RI 02908-5097

401-277-2901

Contact: Jackie Ascrizzi

Target: All ages

Strategy: PI\&E, Distr., Aid Coalition: No

Funding: NA

Project Length: Multi-year

Geographic Area: st., Local

Evaluation: Comprehensive

\section{SOUTH CAROLINA}

Columbiaware

Columbia Medical Society

Auxiliary

438 Hampton Trace Lane

Columbia, SC 29209

803-783-2115

Contact: Paddy Bell

Target: Kids, Parents

Strategy: PI\&E, Distribution Coalition: No

Funding: NA

Project Length: Multi-year

Geographic Area: Local

Evaluation: Limited

\section{SOUTH DAROTA}

Police Department 300 Kansas city st.

Rapid City, SD 57701

Contact: Gary Larson

Target: All ages

Strategy: PI\&E

Coalition: No

Funding: NA

Project Length: Multi-year

Geographic Area: Local

Evaluation: None

\section{TEXAS}

Safety Education Program

Texas A \& M University

Health Education Department

college station, TX 77843

Target: Kids

Strategy: PI\&E

coalition: No

Funding: $\$ 1000-\$ 5000 / y r$.

Project Length: Multi-year

Geographic Area: State

Evaluation: None 


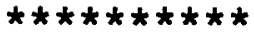 \\ Bicycle Safety Program \\ TX American Automobile Assoc. \\ 3000 Southwest Freeway \\ Houston, TX 77098 \\ 713-524-1851 \\ Contact: Cathy McDonnell \\ Target: Kids, Parents \\ Strategy: PI\&E \\ Coalition: Yes \\ Funding: $\$ 1000-\$ 5000 / y r$. \\ Project Length: Multi-year \\ Geographic Area: Region \\ Evaluation: None
}

\section{UTAH}

PTA

McMillan Elementary school 5900 S. Fashion Blvd.

Murray, UT 84107

Target: Kids, Parents

Strategy: PI\&E, Distribution Coalition: No

Funding: in-kind \& volunteers Project Length: 1 - 3 months Geographic Area: Local

Evaluation: Limited

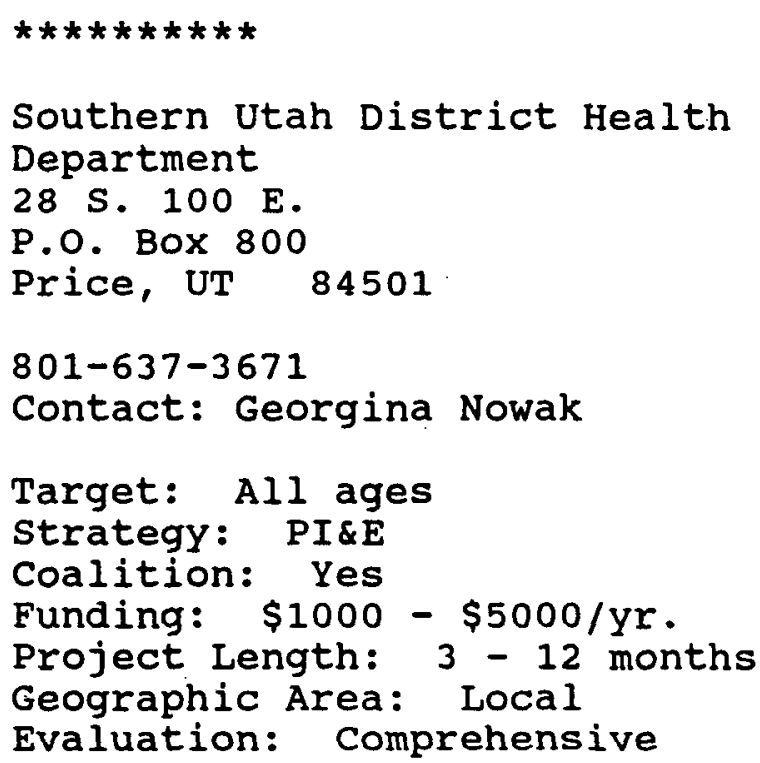

Southern Utah District Health Department

28 S. $100 \mathrm{E}$.

P.O. Box 800

Price, UT 84501

$801-637-3671$

Contact: Georgina Nowak

Target: All ages

Strategy: PI\&E

Coalition: Yes

Funding: $\$ 1000-\$ 5000 / y r$.

Project Length: $3-12$ months

Geographic Area: Local

Evaluation: Comprehensive

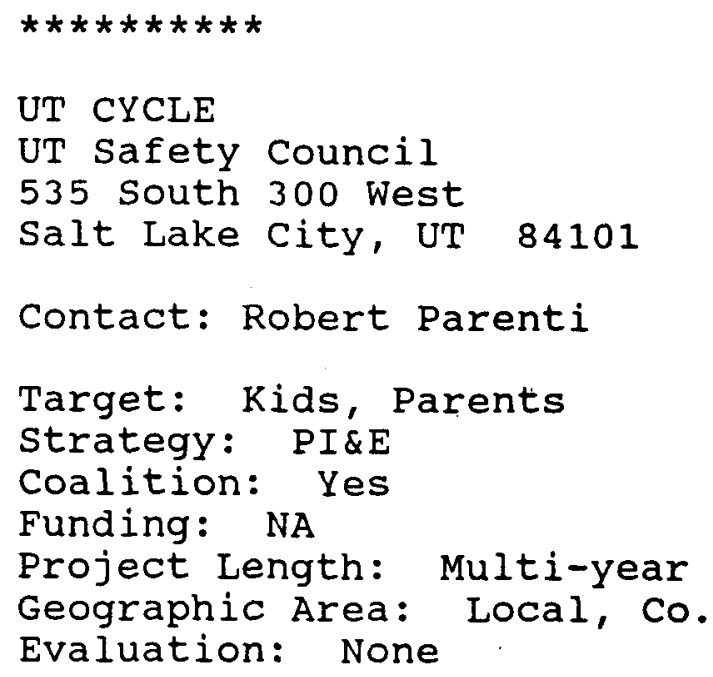

\section{VERMONT}

Bike Rodeo

Police Department

1 South St., P.O. Box 247

Bristol, VT 05443

Contact: Wayne Hunt

Target: Kids

Strategy: PI\&E

Coalition: Yes

Funding: in-kind \& volunteers Project Length: Multi-year

Geographic Area: Local

Evaluation: None

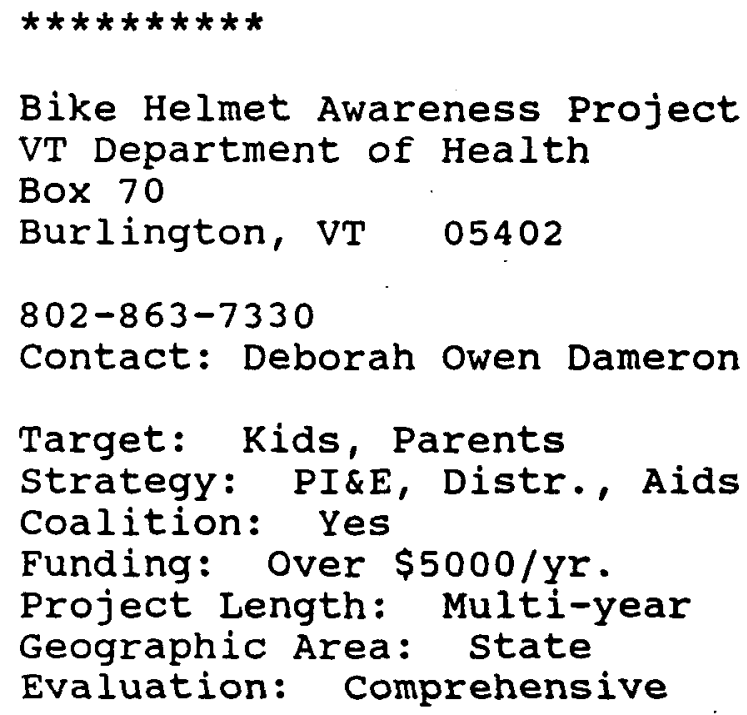

Bike Helmet Awareness Project VT Department of Health

Box 70

Burlington, VT 05402

$802-863-7330$

Contact: Deborah Owen Dameron

Target: Kids, Parents

Strategy: PI\&E, Distr., Aids

Coalition: Yes

Funding: Over $\$ 5000 / y r$.

Project Length: Multi-year

Geographic Area: State

Evaluation: Comprehensive 
Essex Junction Bicycles 50 Pearl st.

Essex Junction, VT 05452

Contact: Larry Fennel

Target: Kids, Teens Strategy: PI\&E, Distribution Coalition: No

Funding: Less than $\$ 500 / y r$. Project Length: Multi-year Geographic Area: Local

Evaluation: Limited

\section{VIRGINIA}

Bicycle Helmet Safety Inst. 4611 Seventh st., South Arlington, VA 22204-1419

703-486-0100

Contact: Randy Swart

Target: All ages

Strategy: PI\&E, Aid

Coalition: Yes

Funding: over $\$ 5000 / \mathrm{yr}$. Project Length: Multi-year Geographic Area: Nat., Inter. Evaluation: Comprehensive

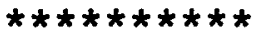

American Safety \& Health Promotions

480 E. Rio Rd.

Charlottesville, VA 22901

804-977-2929

Contact: Douglas olson

Target: Kids

Strategy: PI\&E, Distr., Aid Coalition: No

Funding: NA

Project Length: Multi-year

Geographic Area: Nation

Evaluation: Limited
Parks \& Recreation Department P.O. Box 40

Chesterfield, VA 23832

804-742-1623

Contact: Emily Thorp Kimball

Target: All ages

Strategy: PI\&E, Distr., Aid Coalition: No

Funding: NA

Project Length: Multi-year Geographic Area: Co., Local Evaluation: Comprehensive

Portsmouth Pedals With Pride Hampton Roads SAFE KIDS

PO Box 1775

Norfolk, VA 23501

804-363-3930

Contact: Magie Haley

Target: Kids, all adults

Strategy: PI\&E, Distr., Aid Coalition: Yes

Funding: $\$ 1000-\$ 5000 / \mathrm{yr}$.

Project Length: $3-12$ months Geographic Area: Local

Evaluation: Comprehensive

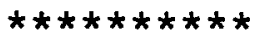

VA SAFE KIDS \& Bike Helmet

Discount Campaign

Department of Health

Division of EMS

1538 E. Parham Rd.

Richmond, VA 23228

Contact: susan Smith

(listing continued next page) 
Target: Kids, Teens

strategy: PI\&E, Distr., Use Coalition: Yes

Funding: $\$ 1000-\$ 5000 / \mathrm{yr}$.

Project Length: Multi-year

Geographic Area: state

Evaluation: Limited

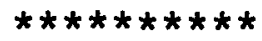

Richmond Area SAFE KIDS

st. Mary's Hospital

5801 Bremo Rd

Richmond, VA 23233.

804-285-2011

Contact: Jan Dalby

Target: Kids, Parents

Strategy: PI\&E, Distribution

Coalition: Yes

Funding: NA

Project Length: Multi-year

Geographic Area: Local

Evaluation: None

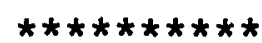

Sell A Bike, Save A Life

Community Traffic Safety

Program/DMV

3551 Buckner Blvd.

Virginia Beach, VA 23456

804-363-3929

Contact: Laura B. Beach

Target: Kids, Adults

Strategy: PI\&E, Aid

Coalition: Yes

Funding: $\$ 1000-\$ 5000 / y r$.

Project Length: Multi-year

Geographic Area: Region, Nat.

Evaluation: Comprehensive

\section{WASHINGTON}

Island School

P.O. Box 154

Bainbridge Island, WA 98061
Contact: Marianne Wiley

Target: Kids, Parents

Strategy: PI\&E, Distribution Coalition: Yes

Funding: in-kind \& volunteers Project Length: 1 - 3 months Geographic Area: Local

Evaluation: Limited

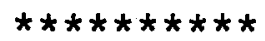

Helmet Coupon Program

Pro-tec

1903962 nd Ave. S.

Kent, WA 98032

206-251-5001

Contact: Sharon Lund

Target: Kids, Parents

Strategy: PI\&E, Distr., Aid

Coalition: Yes

Funding: NA

Project Length: Multi-year

Geographic Area: State

Evaluation: Comprehensive

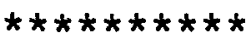

Bike Safety/Helmet Promotion International Bicycle Fund 4887-F Columbia Dr., S.

Seattle, WA 98108

206-767-3927

Contact: David Mozer

Target: Kids

Strategy: PI\&E

Coalition: Yes

Funding: $\$ 1000-\$ 5000 / \mathrm{yr}$.

Project Length: 1 - 3 months Geographic Area: Local

Evaluation: Limited 
Bicycle Helmet Campaign

Harborview Injury Prevention \& Research Center

325 Ninth Ave. $\mathrm{zX}-10$

Seattle, WA 98104

$206-223-3399$

Contact: Lisa Rogers

Target: Kids, Parents

Strategy: PI\&E, Distribution, Use, Aid

Coalition: Yes

Funding: NA

Project Length: Multi-year

Geographic Area: Co., State

Evaluation: Comprehensive

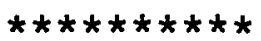

Bike Helmet Campaign

Cascade Bicycle Club

P.O. Box 31299

Seattle, WA 98103

Target: Kids

Strategy: PI\&E, Distr., Aid Coalition: $Y \in S$

Funding: NA

Project Length: Multi-year

Geographic Area: County

Evaluation: Comprehensive

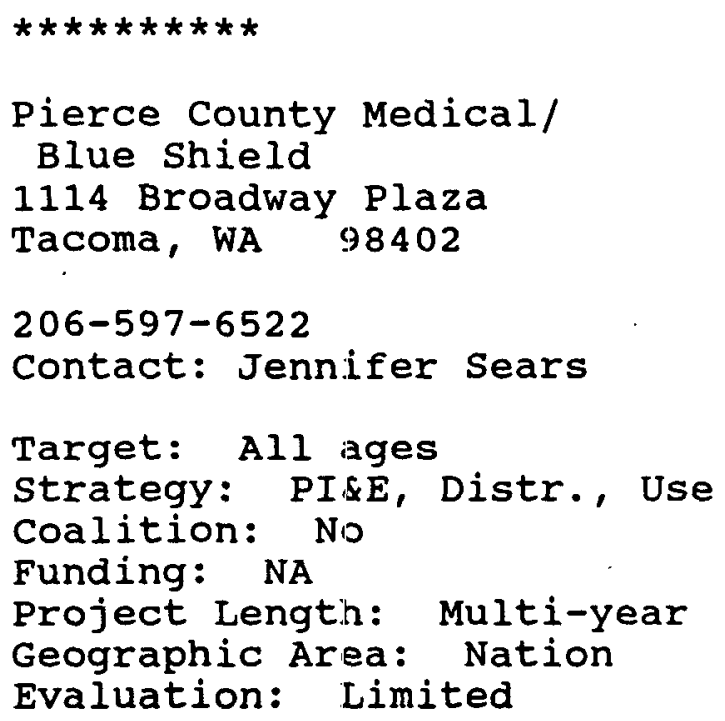

Bicycle Helmet coalition

Sharpstein School District PTA 393 South First Ave

Walla Walla, WA 99362

Contact: Becky Walker

Target: Kids

Strategy: PI\&E, Distribution Coalition: Yes

Funding: in-kind \& volunteers Project Length: Multi-year Geographic Area: Local

Evaluation: Limited

\section{$\star \star * \star * * * * \star \star$}

Head Smart

Children's Bicycle Helmet coalition

County Health Department 310 West poplar

Walla Walla, WA 99362

Target: Kids

Strategy: PI\&E, Distribution Coalition: Yes

Funding: Less than $\$ 500 / y r$.

Project Length: Multi-year

Geographic Area: Local, Nat.

Evaluation: Limited

\section{WISCONSIN}

LAW Bicycle Helmet Week

Bay Shore Bicycle club

P.O. Box 1881

1646 Amy street

Green BaY, WI 54302

414-337-2194

Contact: Sally Ann Peck

Target: All ages

Strategy: PI\&E, Distribution Coalition: Yes

Funding: Less than $\$ 500 / y r$. Project Length: 1 - 3 months Geographic Area: Local

Evaluation: Limited 
Bicycle Helmet promotion

Office of Trans. Safety

Department of Transportation

P.O. Box 7910, Room 809

Madison, WI 53707

608-267-7520

Contact: Susan Kavulich

Target: All ages

Strategy: PI\&E, Aid

Coalition: Yes

Funding: Part of bike program

Project Length: Multi-year

Geographic Area: State

Evaluation: None

$\star * \star \star * \star * \star * * *$

Crash Helmet

Dean Medical Center

1313 Fish Hatchery Rd.

Madison, WI 53715

Target: Kids

Strategy: PI\&E, Distribution

Coalition: Yes

Funding: Over $\$ 5000 / \mathrm{Yr}$.

Project Length: Multi-year

Geographic Area: Co., Local

Evaluation: None

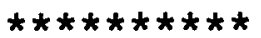

Girl scouts

1897 Lincoln street

Whitehall, WI 54773

Contact: Joanne Selkurt

Target: Kids

Strategy: PI\&E

Coalition: Yes

Funding: in-kind \& volunteers

Project Length: Multi-year

Geographic Area: Local

Evaluation: Limited

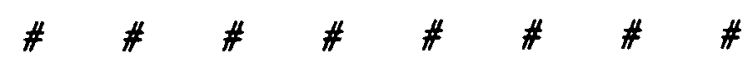




\section{STATE BICYCLE \& PEDESTRIAN COORDINATORS}

\section{ALABAMA}

- William Couch

Bureau of Urban Planning

Alabama State Highway Department

1409 Coliseum Boulevard

Montgomery, AL 36130

205-242-6089; FAX 205-262-7658

\section{ALASKA}

Rich Poor

Bicycle Coordinator

Alaska DOT \& PF

3132 Channel Drive

Juneau, AK $99811-7898$

907-465-6990; FAX 907-465-2460

\section{ARIZONA (f)}

Steve Hancock

Bicycle \& Pedestrian Planner

Transportation Planning Division

Arizona Department of Transportation

- 206 South 17th Avenue, 340B

Phoenix, AZ 85007

602-255-8010; FAX 602-256-7563

\section{CALIFORNIA (f)}

Richard L. Blunden

Chief, Office of Bicycle Facilities

California Department of Transportation

1120 N Street, Room 4500

Sacramento, CA 95814

916-653-0036; FAX 916-654-6583

\section{DISTRICT OF COLUMBIA (p)}

Gilbert Williams

Bicycle \& Pedestrian Coordinator

D.C. Dept of Public Works

2000 14th St, NW, 7th Floor

Washington, DC 20009

202-939-8016; FAX 202-939-7185

FLORDA (f)

Dan Burden

State Bicycle \& Pedestrian Coordinator Florida Department of Transportation 605 Suwannee Street, MS.82

Tallahassee, FL 32399-0450

904-487-1200; FAX 904-922-2935

\section{GEORGIA (f)}

Wayne DeCarli

Bicycle Coordinator

Department of Transportation

24 Wolcott Hill Road

Wethersfield, CT 06109

203-566-6450; FAX 203-566-8943

\section{DELAWARE (p)}

Elizabeth Holloway

Bicycle \& Pedestrian Coordinator

Delaware Department of Transportation

P.O. Box 778

Dover, DE 19903

302-739-5618; FAX 302-739-3447
Steven L. Yost

Bicycle and Pedestrian

Program Coordinator

Georgia Department of Transportation

No. 2 Capital Square - Room 345

Atlanta, GA 30334-1002

404-656-5356

\section{HAWAII (p)}

Kenneth Au or Ronald Tsuzuki Department of Transportation Highways Division 869 Punchbowl Street

Honolulu, HII 96813

808-548-3258

Little Rock, AR 72203

501-569-2115; FAX 501-569-2476

$\begin{array}{ll}\text { (f) full time } & \text { (p) part time }\end{array}$ 


\section{STATE BICYCLE \& PEDESTRIAN COORDINATORS}

\section{ШАHO (f)}

John Barnes

Bicycle Coordinator

DOT Box 7129

Boise, ID $83707-1129$

208-334-8296; FAX 208-334-8583

\section{ILLINOIS (f)}

Craig Williams

Bikeway and Pedestrian Coordinator

Department of Transportation

2300 S. Dirksen Parkway, Room 330

Springfield, II 62764

217-785-2148; FAX 217-524-0989

\section{INDLANA}

Jim Stickler

Chief, Internal Affairs Division Indiana Department of Transportation 100 North Senate Avenue, Room N-730 Indianapolis, IN 46204-2249

317.232-5321; FAX 317-232-0238

IOWA (f)

Nancy Burns

Bicycle Program Coordinator Iowa Department of Transportation 800 Lincoln Way

Ames, LA 50010

515-239-1621; FAX 515-239-1639

\section{KANSAS (p)}

Mark Bechtel

Bicycle Coordinator

Kansas Department of Transportation

2nd Floor, Thacher Bldg

217 SE 4th St.

Topeka, KS 66603

913-296-7448; FAX 913-296-0963

Tom Munz, Bureau of Rail Affairu

\section{KENTUCKY (p)}

Dwayne Clemons

Urban Planning Engineer; 11th Floor

Kentucky Department of Transportation

State Office Building, 11th Floor

Frankfort, KY 40622

502-564-7433; FAX 502-564-6640

or 502-564-4809

\section{LOUISIANA (p)}

Mitchell Lopez

Louisiana Department of Transportation P.O. 94245 Capitol Station

Baton Rouge, LA 70804-9245

504-358-9115; FAX 504-358-9160

MAINE (f)

Margaret Vanderbroek

Bicycle \& Pedestrian Coordinator

Bureau of Planning

Maine Department of Transportation

State House Station 16

Augusta, ME 04333

207-287-3131; FAX 207-287-2896

\section{MARYLAND (f)}

Jerry Stadd

Bicycle \& Pedestrian Coordinator

Maryland State Highway Administration

707 N. Calvert Street, Room 218

PO Box 717

Baltimore, MD 21203-0717

410-333-1145

TOLL FREE (MD) 1-800-252-8776

\section{MASSACHUSETTS (f)}

Josh Lehman

Bicycle-Pedestrian Program Coordinator Massachusetts Highway Department

10 Park Plaza, Room 4150

Boston, MA 02116-3973

617-973-7329; FAX 617-973-8035
MICHIGAN (f)

Terry Eldred

Non-Motorized Coordinator

Bureau of Transportation Planning

P.O. Box 30050

Lansing, MI 48909

517-373-9049; FAX 517-373-9255

\section{MINNESOTA (f)}

Jim Dustrude

State Bicycle Coordinator

Department of Transportation

807 Transportation Building

395 John Ireland Boulevard

St. Paul, MN 55155

612-297-1838; FAX 612-296-3311

\section{MISSISSIPPI (p)}

Jim Moak

Transportation Planner

Mississippi State Highway Department

P.O. Box 1850

Jackson, MS 39215-1850

601-944-9142; FAX 601-944-9150

\section{MISSOURI (p)}

Barbara Grim, Planning Engineer Bicycle \& Pedestrian Coordinator MO Highway and Transportation Dept P.O. Box 270

Jefferson City, MO 65109

314-751-7413; FAX 314-751-6555

\section{MONTANA (p)}

Richard Howell

Bicycle \& Pedestrian Coordinator

Planning \& Programming

Montana Department of Transportation 2701 Prospect Avenue

Helena, MT 59620

406-444-6118; FAX 406-444-7643 


\section{STATE BICYCLE \& PEDESTRIAN COORDINATORS}

NEBRASKA (p)

Dave Schoenmaker

ATTN: Project Development

Nebraska Department of Roads

P.O. Box 94759

Lincoln, NE 68509-4759

402-479-3924; FAX 402-479-4325

\section{NEVADA}

Kent L. Cooper

Bicycle \& Pedestrian Coordinator

Nevada Department of Transportation

Transportation Planning Division

1263 South Stewart Street

Carson City, NV 89712

702-687-4997

\section{NEW HAMPSHIRE (p)}

Stephen Pawlowski

Bicycle Coordinator

NH Department of Transportation

PO Box 483

Concord, NH 03302-0483

603-271-1622; FAX 603-271-3914

\section{NEW JERSEY}

William Feldman

- Pedestrian \& Bicycle Advocate

NJ Department of Transportation

1035 Parkway Avenue

Trenton, NJ 08625

609-530-8062; FAX 609-530-5719

\section{NEW MEXICO (p)}

James Kozak

Bicycle Coordinator

NM Highway and Transportation Dept.

P.O. 1149

Santa Fe, NM 87504-1149

505-988-3302
NEW YORK (f)

Jeffrey Olson

Bicycle \& Pedestrian Program Manager

New York State Dept of Transportation

Urban \& Corridor Planning Bureau

Building 4, Room 206

1220 Washington Avenue

Albany, NY 12232

518-457-3125; FAX 518-457-7960

\section{NORTH CAROLINA (f)}

Curtis B. Yates, Director

Office of Bicycle and Pedestrian

Transportation

North Carolina Dept of Transportation

1 South Wilmington St., Room 422

P.O. Box 25201

Raleigh, NC 27611

919-733-2804; FAX 919-733-1391

\section{NORTH DAKOTA (p)}

Bob Sbannon

Transportation Planner

North Dakota State Highway Department

608 E. Boulevard Ave

Bismarck, ND 58505-0700

701-224-2588; FAX 701-224-4545

OHIO (f)

Sharon Todd

State Bicycle Coordinator

Ohio DOT

25 S. Front Street, Room 308

Columbus, Ohio 43215

614-644-7095; FAX 614-644-6053

\section{OKLAHOMA (p)}

Tim Gatz

Bicycle Coordinator

Urban Design

Oklahoma Department of Transportation

200 N.E. 21 st Street, Room 2-C2

Otlahoma City, OK 73105

405-521-2454; FAX 405-521-6528

\section{OREGON (f)}

Micbael Ronkin

Bikeway Specialist

Oregon DOT

Transportation Building, Room 200

Salem, OR 97310

503-378-3433; FAX 503-378-6811

PENNSYLVANIA (f)

David Bachman

Bicycle \& Pedestrian Program Coordinator PENNDOT

Bureau of Highway Safety

\& Traffic Engineering

P.O. Box 2047, Room 203

Harrisburg, PA 17105-2047

717-787-7350; FAX 717-783-8012

\section{PUERTO RICO (p)}

Martha Bravo Colunga

Bicycle \& Pedestrian Coordinator

Dept of Transportation and Public Works

Box 41269 Minillas Station

San Juan, PR 00940-7269

809-723-3760; FAX 809-727-7792

RHODE ISLAND and Providence Plantation

Constance V. Daniels

Bicycle Coordinator, Planning Division

RI DOT Planning

Two Capital Hill

State Office Building

Providence, RI 02903

401-277-2694; FAX 401-277-6038

\section{SOUTH CAROLINA (f)}

Tom Dodds

Traffic Engineering Department

South Carolina Department of Highways

and Public Transportation

P.O. Box 191

Columbia, SC 29202-0191

803-737-1620; FAX 803-737-6385 


\section{STATE BICYCLE \& PEDESTRIAN COORDINATORS}

\section{SOUTH DAKOTA (p)}

Craig McIntyre

Department of Transportation

Planning \& Programming

700 Broadway Ave East

Pierre, SD 57501-2586

605-773-3155; FAX 605-773-3921

TENNESSEE (p)

William R. Jacobs

Transportation Manager

Tennessee Department of Transportation

James K. Polk Building, Suite 700

505 Deaderick Street

Nashville, TN 37243-0349

615-741-5310; FAX 615-741-2508

\section{TEXAS (f)}

Paul Douglas, Bicycle Coordinator State Department of Highways and

Public Transportation

Dewitt C. Greer State Highway Bldg.

11 th \& Brazos

Austin, TX 78701-2483

512-416-3125; FAX 512-416-3161

Rick Collins, Pedestrian Coordinator

512-416-3122

\section{UTAB (p)}

Kim Morris

Director of Community Relationships

Utah Department of Transportation

4501 South 2700 West

Salt Lake City, UT 84119

801-965-4390; FAX 801-965-4338

\section{VERMONT (f)}

Jodee Anderson

Bicycle \& Pedestrian Coordinator

Vermont Agency of Transportation

Division of RAPT

133 State Street

Montpelier, VT 05633

802-828-2711; FAX 802-828-2829
VIRGINLA (p)

Richard C. Lockwood; Phil Hopkins

Transportation Planning Division

Department of Transportation

1401 E. Broad Street

Richmond, VA 23219

804-786-2964/2985; FAX 804-225-4785

\section{WASHINGTON (f)}

Mike Dornfeld

State Bicycle Coordinator

WA State Dept of Transportation

Highway Transp. Building

Design Office, Room $2 \mathrm{Cll}_{11}$

310 Maple Park Ave, SE

Olympia, WA $98504-7329$

206-705-7258; FAX 206-705-6815

WEST VIRGNIA (p)

Barry Warhoftig

Bicycle and Pedestrian Coordinator

WV DOT Division of Highways

1900 Kanawha St. East

Bldg 5, Room A-550

Charleston, WV 25305-0430

304-558-3063; FAX 304-558-4076

\section{WISCONSIN (f)}

Tom Huber

Div. of Highways and Transp. Services

Wisconsin Department of Transportation

Box 7913

Madison, WI 53707-7913

608-267-7757; FAX 608-267-0294

Catherine Ratté, Manager

Bicycle \& Pedestrian Safety Program

Wisconsin Office of Highway Safety

P.O. Box 7910

Madison, WI $53707-7910$

608-266-0402

\section{WYOMING (f)}

Mr. Kelly Rounds

Bicycle \& Pedestrian Coordinator

Wyoming Department of Transportation

P.O. Box 1708

Cheyenne, WY 82003-1708

307-777-4179; FAX 307-777-4759

\section{AMERICAN SAMOA}

\section{GUAM}

Teresita B. Santos

Highway Safety Coordinator

Guam Public Works

Office of Highway Safety

P.O. Box 2950

Agana, Guam 96910

671-646-3211; FAX 671-646-3733

\section{VIRGIN ISLANDS}




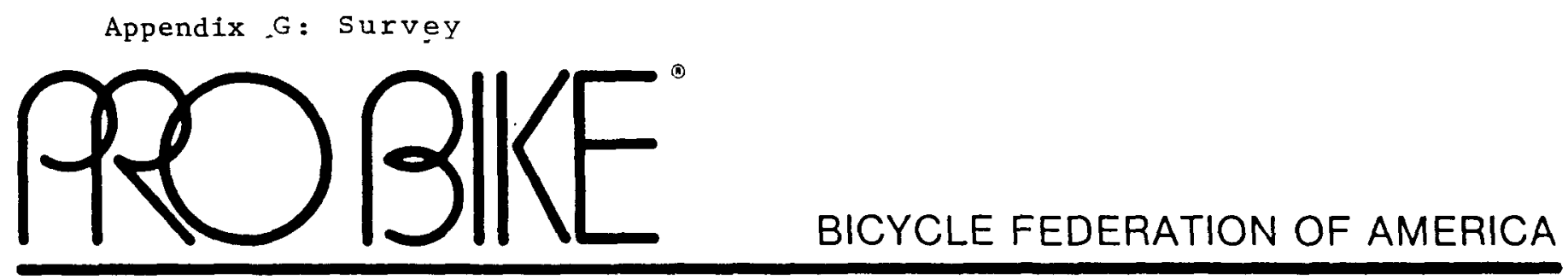

May 1991

Dear Colleague:

I need your help. The Bicycle Federation of America, working with the National Highway Traffic Safety Administration, is reviewing how bicycle helmet use is being promoted in the United States. This information will help us all benefit from each other's challenges and triumphs and become more effective in reducing the incidence of bicycle-related head injuries. The results of this review will also be used to create a state-by-state directory of bicycle helmet promotions.

To complete this review and the development of the directory, I need more information about your efforts to promote bicycle helmet use. I would appreciate 20 minutes of your time to share your experience by completing the enclosed survey. Even if your promotion was conducted in the past, what you did and how you did it is of value to others. Please provide information where you can. If you do not wish to be included in the directory, please indicate this on your completed survey.

Please complete and return your survey to me no later than Friday, June 21, 1991. For your convenience, I have enclosed a stamped, self-addressed envelope for your reply or you may FAX your completed form to me at 406/543-8113.

Thank you in advance for your help. I will make sure you know when the final report and directory are completed this summer. If you have any questions or comments, please call me. The number noted above is both a voice and FAX line.

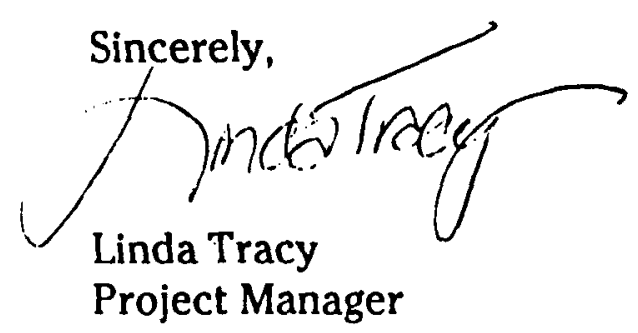

enclosure 


\section{Review of Bicycle \\ Helmet Promotions}

Please complete the survey questions that pertain to your helmet promotion. include additional pages and attachments as necessary.

\section{Contact Information}

Promotion Name:

Lead Agency or Organization:

Address:

City: State: Zip:

If there were other organizations involved, please list them.

How much of your time was spent on this promotion? (time/hours)

How many paid staff worked on this promotion? How many volunteers? 


\section{Promotion Elements}

\section{.}

What were your goals and objectives?"

When did this promotion begin and how long did it last?

What were your funding sources? (Include in-kind contributions)

What was your promotion's level of funding?

What was your target population?

$\square$ to 10 year olds

Children up to 14

$\square$ Parents

$\square$ Adults

$\square 14$ to 19 year olds

$\square$ All ages

$\square$ College students Other

What was your target geographic area?
Nation
$\square$ Region
$\square$ State

County

Local community

Other 
What were your promotion's strategies and components?

What material did you use to achieve your objectives? (Check as many as apply.)

$\square$ Brochures

$\square$ Posters

$\square$ TV PSA's

Radio PSA's

$\square$ Press releases

$\square$ Other

Did you create new materials or use existing materials? Please include ordering information and samples if appropriate.

What type and level of media coverage did your promotion receive? (Feature articles, special event coverage, etc.)

What were the results of your promotion and how did you measure them?

What data did you collect? At which stages did you collect this data? 


\section{Promotion Background}

What was the motivation for beginning your promotion?

What were the essential elements you needed to begin?

What factors helped your promotion?

What barriers did you encounter and how did you overcome them?

What advice would you give others just beginning to promote helmet use?

If your organization has a newsletter or other publication of interest to others in the field, please include details here.

Please return your completed survey by Friday, June 21, 1991 to:

Linda Tracy

Bicycle Federation of America

Montana Office

P.O. Box 8315

Missoula, MT 59807-8315

406/543-8113 (Voice/FAX).

Thank you for your help! 